\title{
5-HT 3 Receptor Antagonists in Neurologic and Neuropsychiatric Disorders: The Iceberg Still Lies beneath the Surface
}

\author{
Gohar Fakhfouri, ${ }^{1}$ Reza Rahimian, ${ }^{1}$ Jonas Dyhrfjeld-Johnsen, Mohammad Reza Zirak, and Jean-Martin Beaulieu \\ Department of Psychiatry and Neuroscience, Faculty of Medicine, CERVO Brain Research Centre, Laval University, Quebec, Quebec, \\ Canada (G.F., R.R.); Sensorion SA, Montpellier, France (J.D.--J.); Department of Pharmacodynamics and Toxicology, School of Pharmacy, \\ Mashhad University of Medical Sciences, Mashhad, Iran (M.R.Z.); and Department of Pharmacology and Toxicology, University of Toronto, \\ Toronto, Ontario, Canada (J.-M.B.)
}

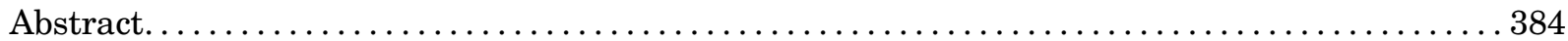

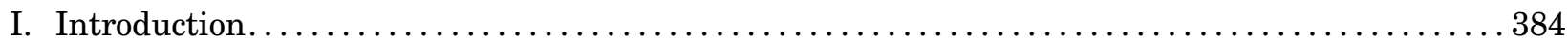

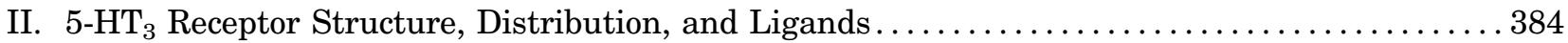

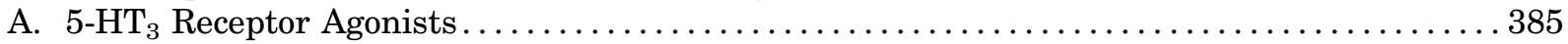

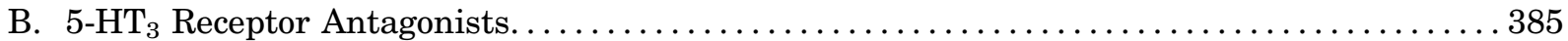

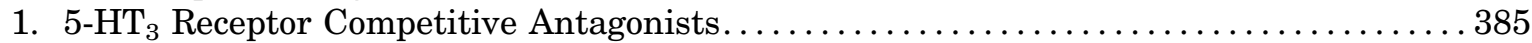

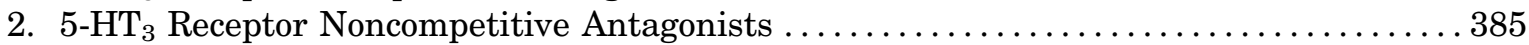



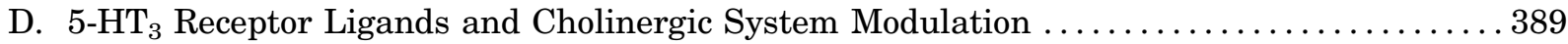

1. Dual 5-HT $\mathrm{HT}_{3}$ Receptor Antagonist/Cholinesterase Inhibitors ................... 389

2. Dual 5-HT ${ }_{3}$ Receptor Antagonists/Nicotinic Receptor Agonists . . . . . . . . . . . . . . . . . 389

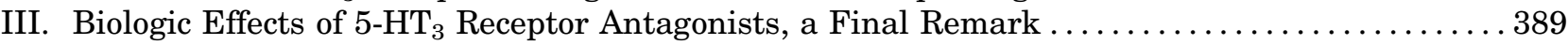

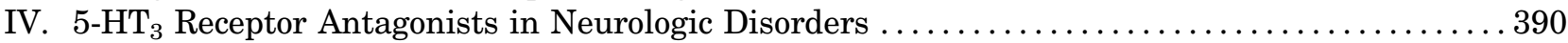

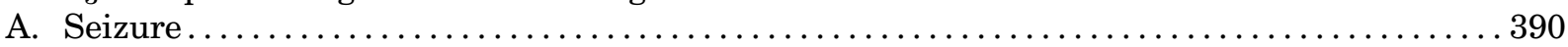

B. Neurotoxicity Associated with Cancer Chemotherapy Drugs ..................... 393

C. Central Component of Irritable Bowel Syndrome ............................ 394

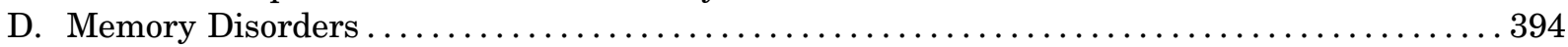



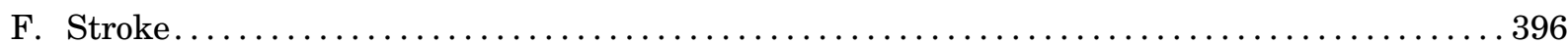

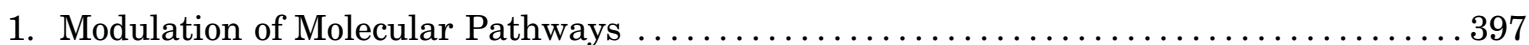

2. Possible Effects on Microglia............................................ 397

3. Effect on Diabetes and Glucose Intolerance as Risk Factors for Stroke............. 398

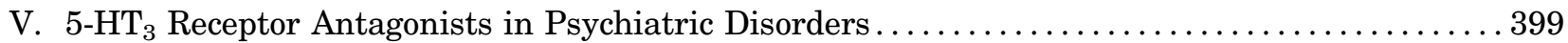

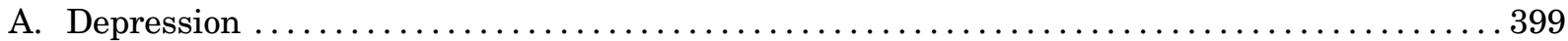



2. Pharmacological Action of Antidepressants on $5-\mathrm{HT}_{3}$ Receptors $\ldots \ldots \ldots \ldots \ldots \ldots \ldots \ldots 400$

3. Human Genetic Findings .......................................... 401

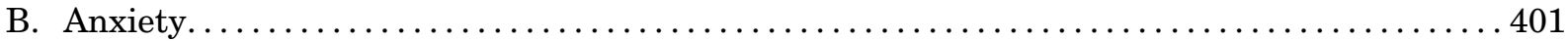

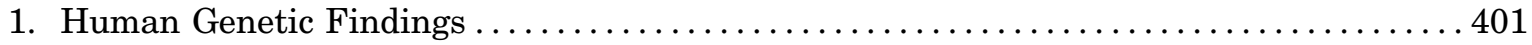

2. Obsessive-Compulsive Disorder .................................. 402

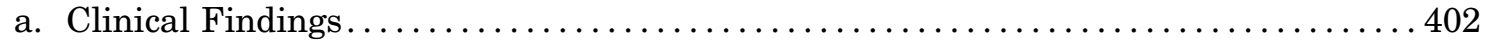

b. Human Genetic Findings........................................ 402

3. Post-Traumatic Stress Disorder, a Different Case ......................... 402

\footnotetext{
Address correspondence to: Dr. Jean-Martin Beaulieu, Department of Pharmacology and Toxicology, Faculty of Medicine, University of Toronto, Medical Science Building, Toronto, ON M5S 1A8, Canada. E-mail: martin.beaulieu@utoronto.ca

This work was supported by grants from the Canadian Institutes of Health Research (CIHR) to J.M.-B. J.M.-B. holds a Canada Research Chair (Tier 1) in Molecular Psychiatry.

${ }^{1}$ G.F. and R.R. contributed equally to this work.

https://doi.org/10.1124/pr.118.015487.
} 
4. Advantageous Adverse Effect Profile of $5-\mathrm{HT}_{3}$ Receptor Antagonists ............. 402

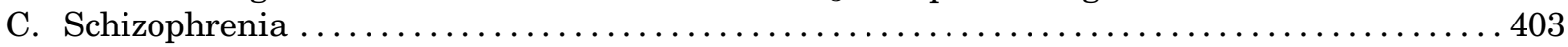

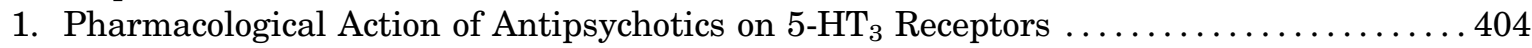

2. Antipsychotic-Induced Parkinsonism ................................ 404

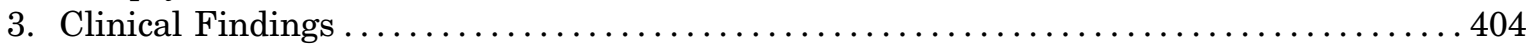

4. Human Genetic Findings ......................................... 404

5. Advantageous Adverse Effect Profile .................................... 405



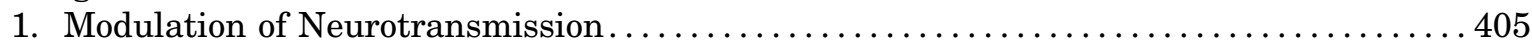

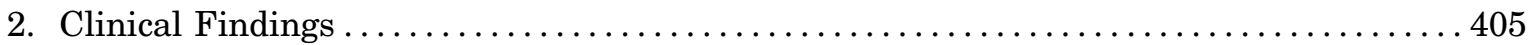

E. Other Neuropsychiatric Disorders .................................. 406

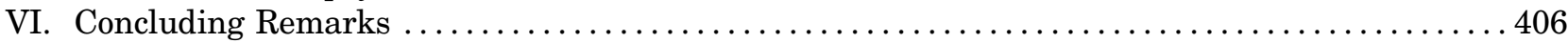

References ................................................... 406

\begin{abstract}
HT}_{3}$ receptor antagonists, first introduced to the market in the mid-1980s, are proven efficient agents to counteract chemotherapy-induced emesis. Nonetheless, recent investigations have shed light on unappreciated dimensions of this class of compounds in conditions with an immunoinflammatory component as well as in neurologic and psychiatric disorders. The promising findings from multiple studies have unveiled several beneficial effects of these compounds in multiple sclerosis, stroke, Alzheimer disease,
\end{abstract}

and Parkinson disease. Reports continue to uncover important roles for $5-\mathrm{HT}_{3}$ receptors in the physiopathology of neuropsychiatric disorders, including depression, anxiety, drug abuse, and schizophrenia. This review addresses the potential of $5-\mathrm{HT}_{3}$ receptor antagonists in neurology- and neuropsychiatry-related disorders. The broad therapeutic window and high compliance observed with these agents position them as suitable prototypes for the development of novel pharmacotherapeutics with higher efficacy and fewer adverse effects.

\section{Introduction}

The monoamine serotonin (5-hydroxytryptamine, 5-HT) is a neurotransmitter engaged in the regulation of a broad spectrum of peripheral and central functions ranging from immunity, gastrointestinal physiology, sexual behavior, and appetite to activity rhythms, pain sensation, mood, emotional states, and cognition (Buhot et al., 2000; Baganz and Blakely, 2013). The diversity and specificity of the various actions of 5-HT arise from the diversity of 5-HT receptor subtypes. The $5-\mathrm{HT}_{3}$ receptor $\left(5-\mathrm{HT}_{3} \mathrm{R}\right)$ occupies a unique place among 5-HTRs because it is the only serotonin-gated cation channel mediating fast excitatory responses, whereas other 5-HT receptor subtypes are coupled to G proteins (Yakel and Jackson, 1988; Maricq et al., 1991). The advent of $5-\mathrm{HT}_{3} \mathrm{R}$ antagonists was a major advancement in the prevention of antineoplastic chemotherapy-induced nausea and vomiting. However, the wide distribution of $5-\mathrm{HT}_{3} \mathrm{R}$ expression suggests that ligands acting on these receptors should have several additional effects that could be of therapeutic interest. Indeed, many recent studies have shown potential effects of $5-\mathrm{HT}_{3} \mathrm{R}$ antagonists in an array of inflammatory, neurodegenerative, and psychiatric diseases. This is of particular clinical relevance since many of these disorders have unmet therapeutic needs due to the inadequate effectiveness and/or multiple unwanted effects by conventional medications, which compromise patient compliance and therefore the success rate of pharmacotherapy.

In this comprehensive review, we discuss $5-\mathrm{HT}_{3} \mathrm{Rs}$ and their expression pattern and structural organization. In addition, we discuss the potential utility of pharmacological agents acting as $5-\mathrm{HT}_{3} \mathrm{R}$ antagonists for the treatment of neuropathologies as diverse as seizure, stroke, memory disorders, inner ear diseases, schizophrenia, depression, anxiety disorders, and drug addiction. In doing so, we will pay special attention not only to effects that can be mediated by $5-\mathrm{HT}_{3} \mathrm{Rs}$ but also to complementary effects that could be explained by an action of these compounds on additional pharmacological targets.

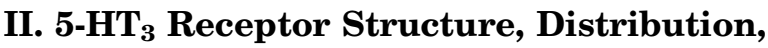 and Ligands}

The structure and function of $5-\mathrm{HT}_{3} \mathrm{Rs}$ indicates that they belong to the Cys-loop family of ligand-gated ion

ABBREVIATIONS: 5-HT, 5-hydroxytryptamine; 5- $\mathrm{HT}_{3} \mathrm{R}, 5-\mathrm{HT}_{3}$ receptor; AAS, anabolic androgenic steroid; ACh, acetylcholine; AChE, acetylcholinesterase; $\mathrm{AD}$, Alzheimer disease; $\mathrm{BLA}$, basolateral subregion; $\mathrm{CB}_{1} \mathrm{R}$, cannabinoid type 1 receptor; CNS, central nervous system; $\mathrm{CRH}$, corticotropin-releasing hormone; CS, conditional stimulus; DA, dopamine; DRN, dorsal raphe nucleus; FST, forced swim test; HPA, hypothalamic-pituitary-adrenal; IBS, irritable bowel syndrome; IL, interleukin; LC, locus coeruleus; LPS, lipopolysaccharide; $m$-CPBG, $m e t a$ chlorophenyl-biguanide; MAPK, mitogen-activated protein kinase; MDL 72222, C15H18Cl3NO2; NAc, nucleus accumbens; nAChR, nicotinic acetylcholine receptor; NE, norepinephrine; NO, nitric oxide; OCD, obsessive-compulsive disorder; PD, Parkinson disease; PFC, prefrontal cortex; PPAR $\gamma$, peroxisome proliferator-activated receptor $\gamma$; PTSD, post-traumatic stress disorder; PTZ, pentylenetetrazol; RG3487, C15H19ClN4O; SNP, single nucleotide polymorphism; SR57227, C10H15Cl2N3; SSRI, selective serotonin reuptake inhibitor; TCA, tricyclic antidepressant; US, unconditional stimulus; VTA, ventral tegmental area. 
channels, which also includes nicotinic acetylcholine receptors (nAChRs) and $\mathrm{GABA}_{\mathrm{A}}$ receptors. $5-\mathrm{HT}_{3} \mathrm{R}$ is composed of five subunits surrounding a central ionconducting pore that is permeable to sodium, potassium, and calcium ions (Faerber et al., 2007). Each subunit comprises extracellular, transmembrane, and intracellular domains. The extracellular domain contains the binding site for ligands such as agonists and competitive antagonists and constitutes the major therapeutic target within $5-\mathrm{HT}_{3} \mathrm{R}$. Thus far, genes for five $5-\mathrm{HT}_{3}$ subunits have been identified (A-E), which encode proteins that bear differences in the $\mathrm{N}$-terminal and transmembrane regions. Despite what was assumed earlier, all $5-\mathrm{HT}_{3}$ subunits are expressed in the central nervous system (CNS). Inclusion of A subunits renders the receptors functional, giving rise to homomeric $5-\mathrm{HT}_{3 \mathrm{~A}}$ or heteromeric $5-\mathrm{HT}_{3} \mathrm{Rs}$ expressed on neurons (Miyake et al., 1995; Fiebich et al., 2004b; Thompson and Lummis, 2007; Thompson et al., 2010). Although heteromeric receptors containing $5-\mathrm{HT}_{3 \mathrm{C}}, 5-\mathrm{HT}_{3 \mathrm{D}}$, or $5-\mathrm{HT}_{3 \mathrm{E}}$ subunits possess 5-HT-induced responses and biophysical properties similar to those of homomeric $5-\mathrm{HT}_{3 \mathrm{~A}}$ receptors, little is known about their pharmacology (Niesler et al., 2007). Heteromeric $5-\mathrm{HT}_{3 \mathrm{~A} / \mathrm{B}}$ receptors, on the other hand, show disparate characteristics. These compositions differ greatly in single channel conductance, calcium permeability, 5-HT concentration-response curves, desensitization rate, and current-voltage relationships (Davies et al., 1999; Kelley et al., 2003b; Peters et al., 2010; Thompson and Lummis, 2013).

$5-\mathrm{HT}_{3} \mathrm{Rs}$ are found in both the CNS and peripheral nervous system. They are expressed in many brain regions, including the hippocampus, entorhinal cortex, frontal cortex, cingulate cortex, amygdala, nucleus accumbens (NAc), substantia nigra, and ventral tegmental area (VTA), with the highest densities in the area postrema and the nucleus tractus solitaries, regions responsible for the vomiting reflex (Thompson and Lummis, 2006). Activation of presynaptic 5- $\mathrm{HT}_{3} \mathrm{Rs}$ causes a rapid rise in cytosolic calcium concentration by inducing calcium influx, thereby modulating the release of a long list of neurotransmitters and neuropeptides. Postsynaptic $5-\mathrm{HT}_{3} \mathrm{Rs}$ are associated with fast excitatory sodium and potassium-dependent depolarization (Krzywkowski et al., 2008). Moreover, depending on the type of neurons studied, presynaptic and postsynaptic $5-\mathrm{HT}_{3} \mathrm{Rs}$ differ in cellular localization across different brain areas (Thompson and Lummis, 2006).

When the distribution of HTR3A and HTR3B in the human brain was interrogated by means of mRNA analyses, both subunits were detected in all brain regions studied except the cerebellum. However, the $\mathrm{A} / \mathrm{B}$ subunit ratio varied drastically across different brain regions. Intriguingly, HTR $3 B$ has the highest expression in many brain areas with relevance to psychiatric disorders, namely the brain stem, amygdala, and frontal cortex (Hammer et al., 2012), raising the possibility of a role for altered stoichiometry/function of $5-\mathrm{HT}_{3} \mathrm{R}$ subunits in the pathomechanism of such afflictions. Apart from the CNS, the $5-\mathrm{HT}_{3 \mathrm{~A}}$ subunit has been detected in nonneural cells such as $\mathrm{T}$ cells, monocytes, synovial tissue, and primary chondrocytes (Thompson and Lummis, 2013).

The multiple possibilities in subunit combinations along with diverse patterns of tissue-specific distribution and pharmacological/biophysical properties make $5-\mathrm{HT}_{3} \mathrm{Rs}$ an attractive candidate for novel therapeutic targets (Thompson and Lummis, 2013).

\section{A. 5-HT $\mathrm{T}_{3}$ Receptor Agonists}

Apart from serotonin as the endogenous amine agonist, various $5-\mathrm{HT}_{3} \mathrm{R}$ agonists have been synthesized as pharmacological tools. A handful of other compounds have been found to activate these receptors (Table 1). One of the most selective and potent agonists is metachlorophenyl-biguanide ( $m$-CPBG). The agonists at $5-\mathrm{HT}_{3} \mathrm{R}$ do not usually possess any important clinical indication, as they are extremely emetogenic and can lead to hyperalgesia (Kilpatrick et al., 1990). Varenicline, a partial agonist at $\alpha 4 \beta 2 \mathrm{nAChR}$ that has been approved for smoking cessation, is also a partial agonist at $5-\mathrm{HT}_{3} \mathrm{R}$ (Rollema et al., 2007). This property could be responsible for nausea, the most common adverse effect reported with varenicline in smoking cessation trials (Neve et al., 1991; Gonzales et al., 2006). The application of $5-\mathrm{HT}_{3} \mathrm{R}$ agonists is thus mostly confined to experimental studies to decipher the unknown roles of these receptors in physiologic and pathologic conditions (Thompson, 2013).

\section{B. 5-HT $\mathrm{T}_{3}$ Receptor Antagonists}

1. 5-HT $\mathrm{T}_{3}$ Receptor Competitive Antagonists. To date, nausea and vomiting are the most prescribed therapeutic indications of competitive $5-\mathrm{HT}_{3} \mathrm{R}$ antagonists (the setron family). Setrons have revolutionized oncology by potently treating chemotherapy-induced nausea and vomiting. The use of alosetron in diarrhea-predominant irritable bowel syndrome (IBS) has been hampered by its life-threatening adverse effect of ischemic colitis in a subset of patients. Recent investigations have focused more on palonosetron, a second-generation $5-\mathrm{HT}_{3} \mathrm{R}$ antagonist. Palonosetron is highly selective for $5-\mathrm{HT}_{3} \mathrm{R}$ and possesses greater affinity, a longer plasma half-life, and improved efficacy in preventing chemotherapy-induced nausea and vomiting compared with first-generation setrons (Rojas et al., 2010; Thompson, 2013). A detailed list of competitive antagonists is shown in Table 1.

2. 5-HT $T_{3}$ Receptor Noncompetitive Antagonists. Noncompetitive antagonists bind to locations other than the orthosteric binding site and therefore their action cannot be overcome by the addition of an agonist. The number of these antagonists is increasing dramatically. Noncompetitive antagonists at $5-\mathrm{HT}_{3} \mathrm{Rs}$ can generally be classified into plant-derived and synthesized 


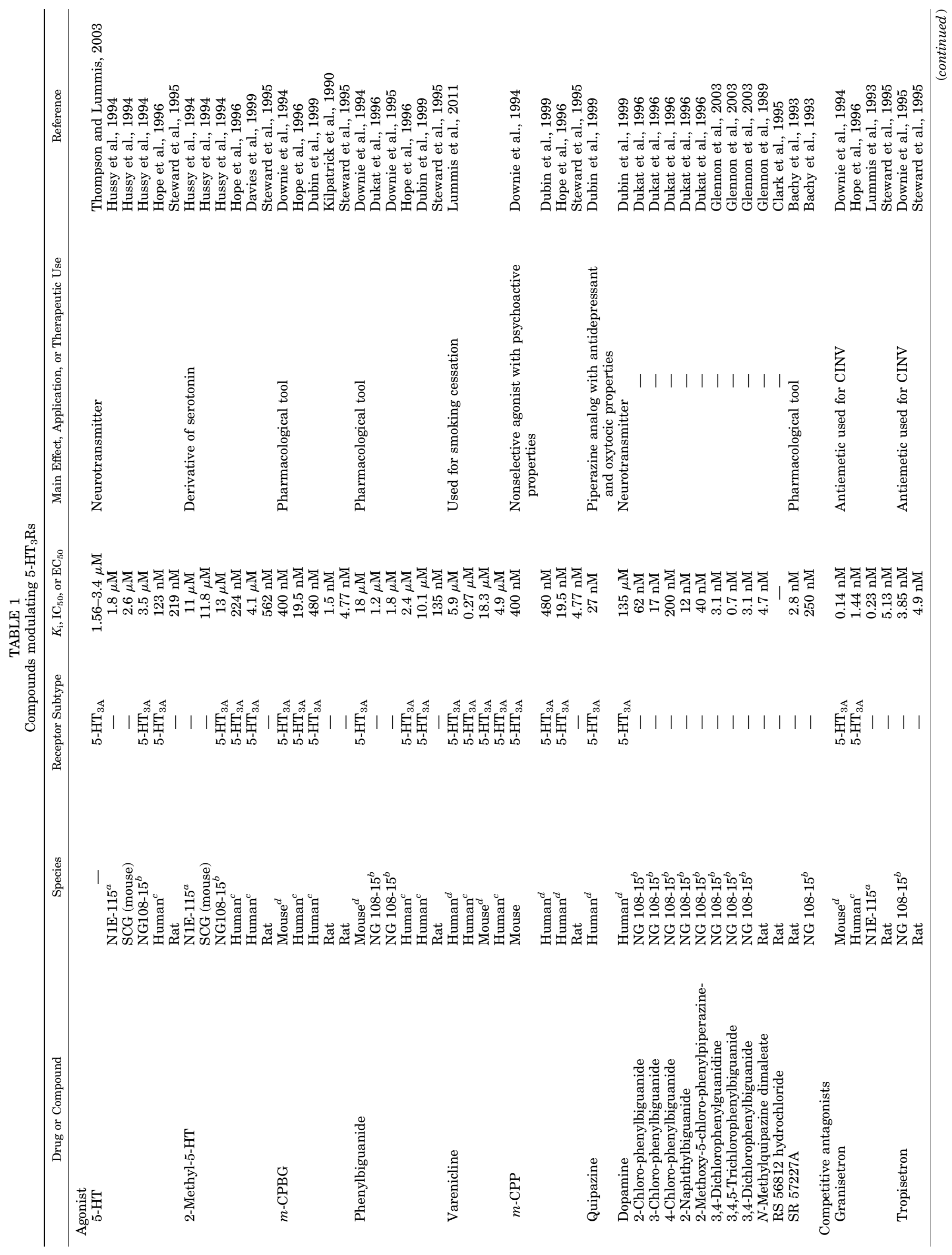




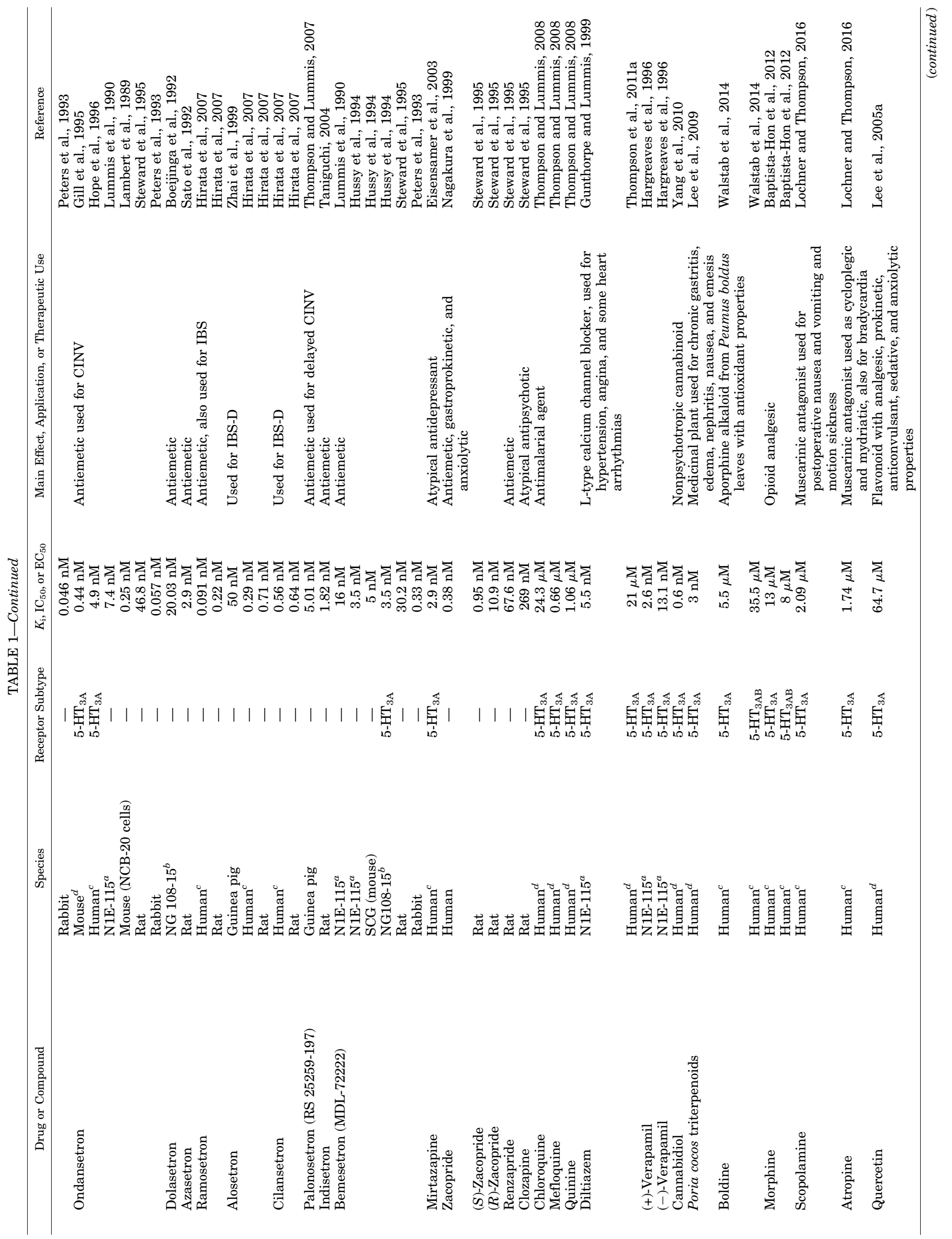




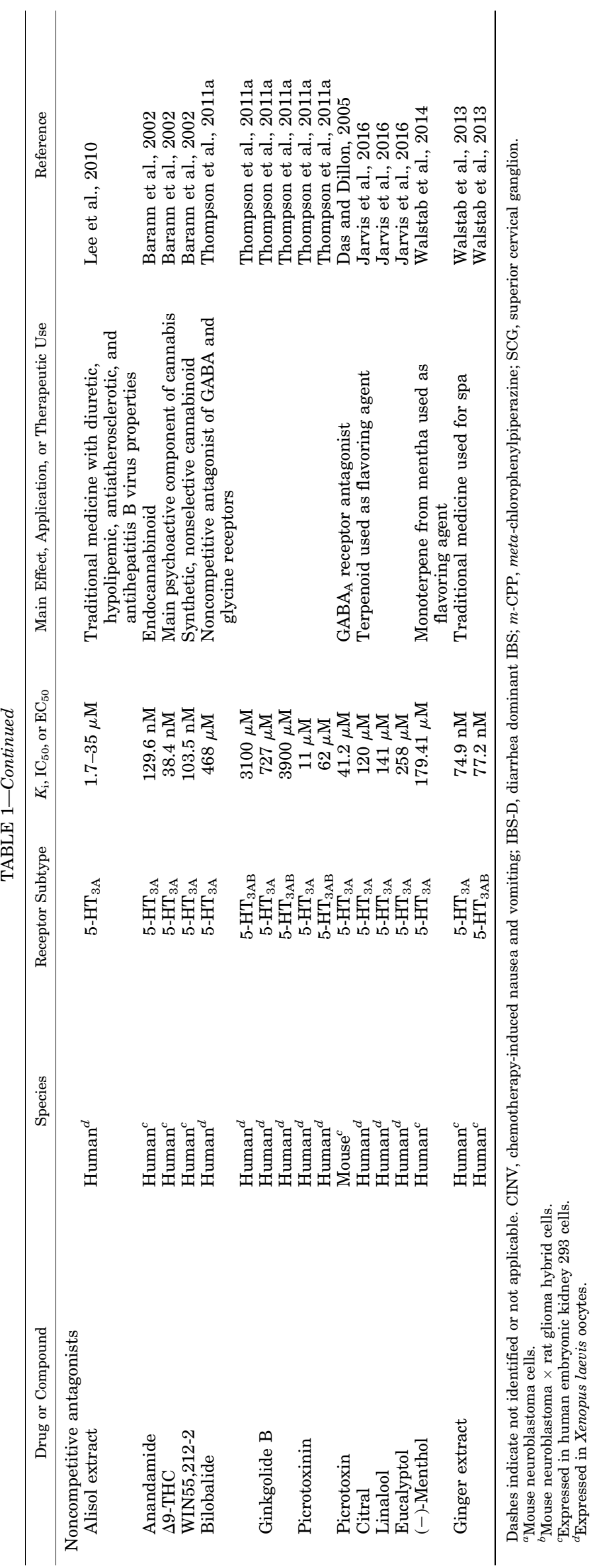


antagonists (Table 1). Cannabinoids (tetrahydrocannabinol), quinine, ginkgolides, resveratrol, ginseng, and liquorice are important examples of the former class, whereas antimalarial compounds (quinine and mefloquine) and diltiazem belong to the latter (Thompson et al., 2007, 2011a,b; Thompson and Lummis, 2008; Walstab et al., 2010). Intriguingly, $5-\mathrm{HT}_{3} \mathrm{R}$ antagonists and cannabinoids share several pharmacological properties such as analgesic, anti-inflammatory, and antiemetic effects. These common properties imply that $5-\mathrm{HT}_{3} \mathrm{Rs}$ can be closely involved in various pharmacological aspects of cannabinoids, and this dimension is of relevance for designing cannabinoid derivatives with fewer psychoactive effects (Rahimian et al., 2011b).

Steroids are also noncompetitive inhibitors of $5-\mathrm{HT}_{3} \mathrm{R}$ at pharmacological concentrations (Walstab et al., 2010; Davies, 2011). Generally, steroid-induced response is not rapid because steroids target gene-response elements downstream of activating their cytoplasmic receptors. The clinical importance of $5-\mathrm{HT}_{3} \mathrm{R}$ antagonism by steroids is that it may justify some of the rapid actions seen with steroids (sex hormones and glucocorticoids) such as antiemetic and analgesic properties.

Since $5-\mathrm{HT}_{3} \mathrm{R}$ is a ligand-gated cation channel, the response triggered by its modulation is fast. Noncompetitive antagonists have differential potencies at $5-\mathrm{HT}_{3 \mathrm{~A}}$ and $5-\mathrm{HT}_{3 \mathrm{AB}}$ receptors. This characteristic makes them suitable experimental tools for distinguishing $5-\mathrm{HT}_{3} \mathrm{R}$ subtypes in tissues. Because of their off-target effects and in some cases their low potency, however, the importance and clinical potential of noncompetitive antagonists is still unknown (Thompson, 2013).

\section{5-HT $\mathrm{H}_{3}$ Receptor Allosteric Modulators}

Allosteric modulators of $5-\mathrm{HT}_{3} \mathrm{Rs}$ can be categorized as positive and negative modulators (Table 1). The first class facilitates channel opening, whereas the second class increases the energy barrier for gating and reduces the probability of channel opening (Thompson, 2013). A number of compounds have been shown to modulate $5-\mathrm{HT}_{3} \mathrm{R}$, including general anesthetics, local anesthetics, steroids, antidepressants, and antipsychotics (Fan, 1994; Davies, 2011). This can be of translational relevance, as identification of novel targets for antidepressants and antipsychotics is crucial to minimizing the adverse effects of these widely prescribed drugs and opens avenues for the development of ligands with higher efficacies. This topic is discussed in detail in sections V.A and V.C.

\section{5-HT $T_{3}$ Receptor Ligands and Cholinergic System Modulation}

1. Dual 5-HT $\mathrm{T}_{3}$ Receptor Antagonist/Cholinesterase Inhibitors. An analog of tacrine, an acetylcholinesterase (AChE) inhibitor, has been synthesized and demonstrates a nanomolar affinity for both $5-\mathrm{HT}_{3} \mathrm{R}$ and human AChE, whereas its potency in inhibiting butyrylcholinesterase is 10 -fold lower. To this end, tacrine was fused with a spacer to an optimized $5-\mathrm{HT}_{3} \mathrm{R}$ antagonist. Hypothetically, such compounds might act to enhance acetylcholine (ACh) bioavailability through $\mathrm{AChE}$ inhibition, which is progressively diminished in the Alzheimer disease $(\mathrm{AD})$-inflicted brain and to interfere with the neurodegenerative events underpinning the disorder by antagonizing $5-\mathrm{HT}_{3} \mathrm{Rs}$ (Cappelli et al., 2005). However, tacrine therapy is associated with a very high rate of serum aminotransferase elevation over the course of therapy and with several instances of clinically conspicuous, acute liver injury (Alfirevic et al., 2007). Therefore, for a more translational approach, other cholinesterase inhibitors with safer profiles should replace tacrine.

2. Dual 5-HT 3 Receptor Antagonists/Nicotinic Receptor Agonists. RG3487 (C15H19ClN4O), a 5-HT ${ }_{3} \mathrm{R}$ antagonist with $\alpha 7 \mathrm{nAChR}$ partial agonistic activity, significantly improved cognitive performance in rats (Rezvani et al., 2009). This ligand was later shown to enhance dopamine (DA) and ACh release in the medial prefrontal cortex (PFC) and hippocampus but not the NAc. The effect on both DA and ACh was dose dependent, with the former relying on $\alpha 7 \mathrm{nAChR}$ stimulation whereas the latter was mediated by $5-\mathrm{HT}_{3} \mathrm{R}$ antagonism (Huang et al., 2014). By targeting different receptors, this dual-acting compound can offer additional or synergistic benefits in debilitating diseases with a progressive nature such as $\mathrm{AD}$ and Parkinson disease (PD). Such multimodal action could provide high effectiveness for treating or delaying the progression of neurodegenerative disorders. Therefore, these pharmacotherapeutics can also serve as a scaffold to develop new agents that target both inflammation and neurodegenerative events.

\section{Biologic Effects of 5-HT 3 Receptor Antagonists, a Final Remark}

In addition to an antagonistic action on their classic target $5-\mathrm{HT}_{3} \mathrm{R}$, recent investigation associates setrons with other surface and intracellular molecules. Studies show that a number of protective actions of some setrons may not be merely explained through interaction with their conventional site of action. Indeed, important signaling molecules such as mitogen-activated protein kinase (MAPK) (Liu et al., 2012, 2016), calcineurin (Vega Lde et al., 2005; Rahimian et al., 2011b, 2013b; Dyhrfjeld-Johnsen, 2016), and $\alpha 7$ nAChRs (Macor et al., 2001; Ishikawa et al., 2011) are affected by $5-\mathrm{HT}_{3} \mathrm{R}$ antagonists. Since many of these new targets are implicated in neurologic and neuropsychiatric diseases with unmet therapeutic needs, addressing them from various fronts by means of $5-\mathrm{HT}_{3} \mathrm{R}$ antagonists is tantalizing. Indeed, the concept of employing selective pharmacotherapeutics has been challenged by the fact that the complex nature of these diseases requires a 
multifaceted therapy strategy. Such an approach can be achieved by $5-\mathrm{HT}_{3} \mathrm{R}$ antagonists.

Among the various classes of $5-\mathrm{HT}_{3} \mathrm{R}$ ligands, only setrons have a place in pharmacotherapy, whereas other ligands merely serve as experimental tools. In the following sections, we provide an overview of these various pharmacological actions of $5-\mathrm{HT}_{3} \mathrm{R}$ antagonists in neurologic and neuropsychiatric disorders.

\section{5-HT 3 Receptor Antagonists in Neurologic Disorders}

\section{A. Seizure}

It is becoming increasingly evident that serotonergic neurotransmission plays a major role in chemically and electrically evoked seizures. $5-\mathrm{HT}_{3} \mathrm{Rs}$ are among the 5 -HT receptor subtypes with an established contribution to epileptogenesis and/or propagation (Pytka et al., 2017; Zhao et al., 2018). It is generally accepted that agents that enhance extracellular 5-HT content inhibit both focal and generalized seizures. Examples include 5-HT precursor 5-hydroxytryptophan and selective serotonin reuptake inhibitors (SSRIs). In contrast, agents that lower brain 5-HT levels decrease the seizure threshold. In line with this notion, many antiepileptics elevate endogenous extracellular 5-HT levels (Bagdy et al., 2007).

However, both anticonvulsant and proconvulsant properties have been reported with $5-\mathrm{HT}_{3} \mathrm{R}$ antagonists (Tables 2 and 3). This implies that their pharmacological effects on seizure threshold depend on various factors, including dose-related sensitivity of physiologic pathways, differences in ligand pharmacodynamics and pharmacokinetics, and dissimilarity of experimental seizure models used (Mishra and Goel, 2016). Dissecting these opposing properties of $5-\mathrm{HT}_{3} \mathrm{R}$ antagonists is of pharmacological significance both in terms of drug development and management of neurologic adverse effects of $5-\mathrm{HT}_{3} \mathrm{R}$ antagonists.

Seizures occur in $13 \%$ of all patients with cancer, comprising approximately $5 \%$ of neurologic manifestations (Clouston et al., 1992). The occurrence of seizures in patients with cancer might stem from a variety of causes such as cytotoxic chemotherapy, brain parenchymal and meningeal metastasis, and toxic-metabolic encephalopathy. The proconvulsant potential of $5-\mathrm{HT}_{3} \mathrm{R}$ antagonists should be considered in chemotherapy regimens. Therefore, caution is advised when coadministering $5-\mathrm{HT}_{3} \mathrm{R}$ antagonists with chemotherapeutic agents (e.g., cisplatin, methotrexate, chlorambucil, and busulphan) that can potentiate the development of convulsions (Singh et al., 2007), especially in a subset of patients prone to seizure such as those suffering from brain tumors (Gharedaghi et al., 2014).

The use of $5-\mathrm{HT}_{3} \mathrm{Rs}$ agonists as antiepileptic agents in humans is not a therapeutic option, considering the presence of these receptors on afferent vagal nerve fibers and neurons in the chemoreceptor trigger zone. Therefore, $5-\mathrm{HT}_{3} \mathrm{R}$ stimulation can potentially cause bradycardia, nausea, and vomiting (Jeggo et al., 2005; Tuerke et al., 2012). Regarding the established place of $5-\mathrm{HT}_{3} \mathrm{R}$ antagonists in chemotherapy regimens, it is crucial to elucidate the mechanisms by which they modulate the seizure threshold.

A number of studies have reported generalized tonicclonic seizures with setrons in children and adults (Sargent et al., 1993; Sharma and Raina, 2001; George et al., 2008; Singh et al., 2009; Patel et al., 2011). A study showed that SR57227 (C10H15Cl2N3) increases, but granisetron decreases, the threshold for pentylenetetrazol (PTZ)-induced clonic seizures in mice (Gholipour et al., 2010). In the same model, $m$-CPBG potentiated the additive anticonvulsant properties of morphine and citalopram, whereas tropisetron abolished such an additive effect, pointing to the $5-\mathrm{HT}_{3} \mathrm{R}$ dependence of the effect (Bahremand et al., 2011; Payandemehr et al., 2012; Gharedaghi et al., 2014). In line with these findings, MDL $72222(\mathrm{C} 15 \mathrm{H} 18 \mathrm{Cl} 3 \mathrm{NO} 2)$ aggravates seizures evoked by ethanol withdrawal in mice (Grant et al., 1994) (Tables 1 and 2).

$5-\mathrm{HT}_{3} \mathrm{Rs}$ are expressed in virtually all of the networks engaged in epileptogenesis, mainly on GABAergic interneurons in the amygdala, hippocampus, and neocortex. Their activation by 5 -HT or selective agonist $m$-CPBG eventually leads to hyperpolarization of neurons in these brain regions (Ropert and Guy, 1991; Hornung and Celio, 1992; Tecott et al., 1993; Kawa, 1994; Stäubli and Xu, 1995; McMahon and Kauer, 1997; Katsurabayashi et al., 2003; Brady et al., 2007). Conversely, $5-\mathrm{HT}_{3} \mathrm{Rs}$ antagonists reduce the firing rate of hippocampal inhibitory interneurons, thereby increasing the discharge rate of pyramidal cells in this region (Reznic and Staubli, 1997). Based on these pieces of evidence, it is plausible that activation of brain inhibitory interneurons through $5-\mathrm{HT}_{3} \mathrm{Rs}$ stimulation plays an important role in the anticonvulsant effect of SSRIs and agonists at $5-\mathrm{HT}_{3} \mathrm{Rs}$ (Gholipour et al., 2010). Another explanation for the observed proconvulsant actions of $5-\mathrm{HT}_{3} \mathrm{R}$ antagonists (Table 2) is the ability found with a subset of them, including tropisetron, to inhibit calcineurin activity (Rahimian et al., 2011b). The calcium-activated serine/ threonine phosphatase calcineurin is highly abundant in the brain, accounting for more than $1 \%$ of the total protein, and regulates transcription and activity state of multiple signaling molecules (Klee et al., 1998; Rusnak and Mertz, 2000). Administration of classic calcineurin inhibitors such as cyclosporin $\mathrm{A}$, as an immunosuppressant for graft rejection, induced seizure in a cohort of patients (Gleeson et al., 1998; Zakrzewski, 2003).

However, some studies reported a proconvulsive effect for $5-\mathrm{HT}_{3} \mathrm{R}$ stimulation. Ondansetron has been reported to exert anticonvulsant activity and potentiate the anticonvulsant effect of phenytoin in maximal electroshock-induced seizures in rats (Balakrishnan 


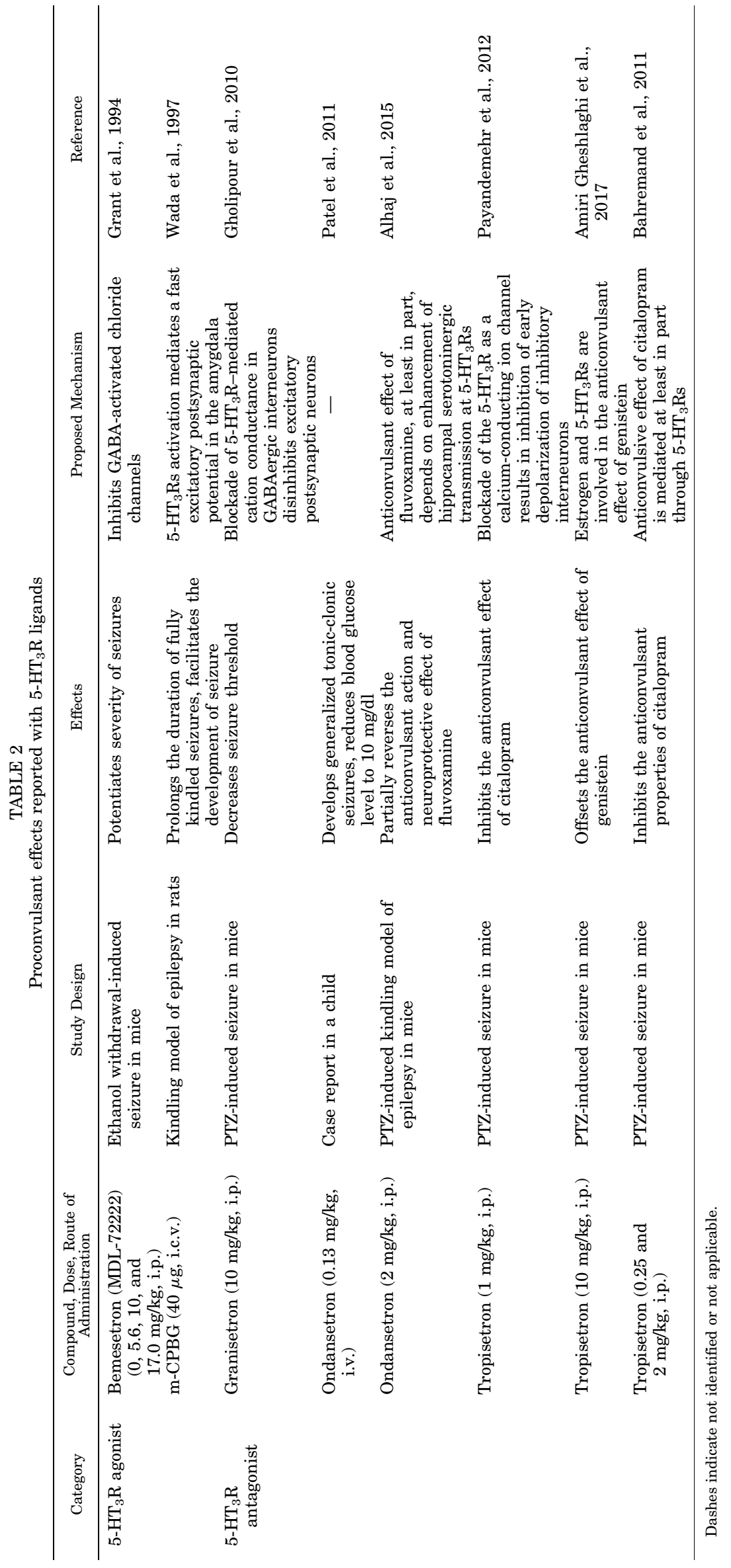


Fakhfouri et al.

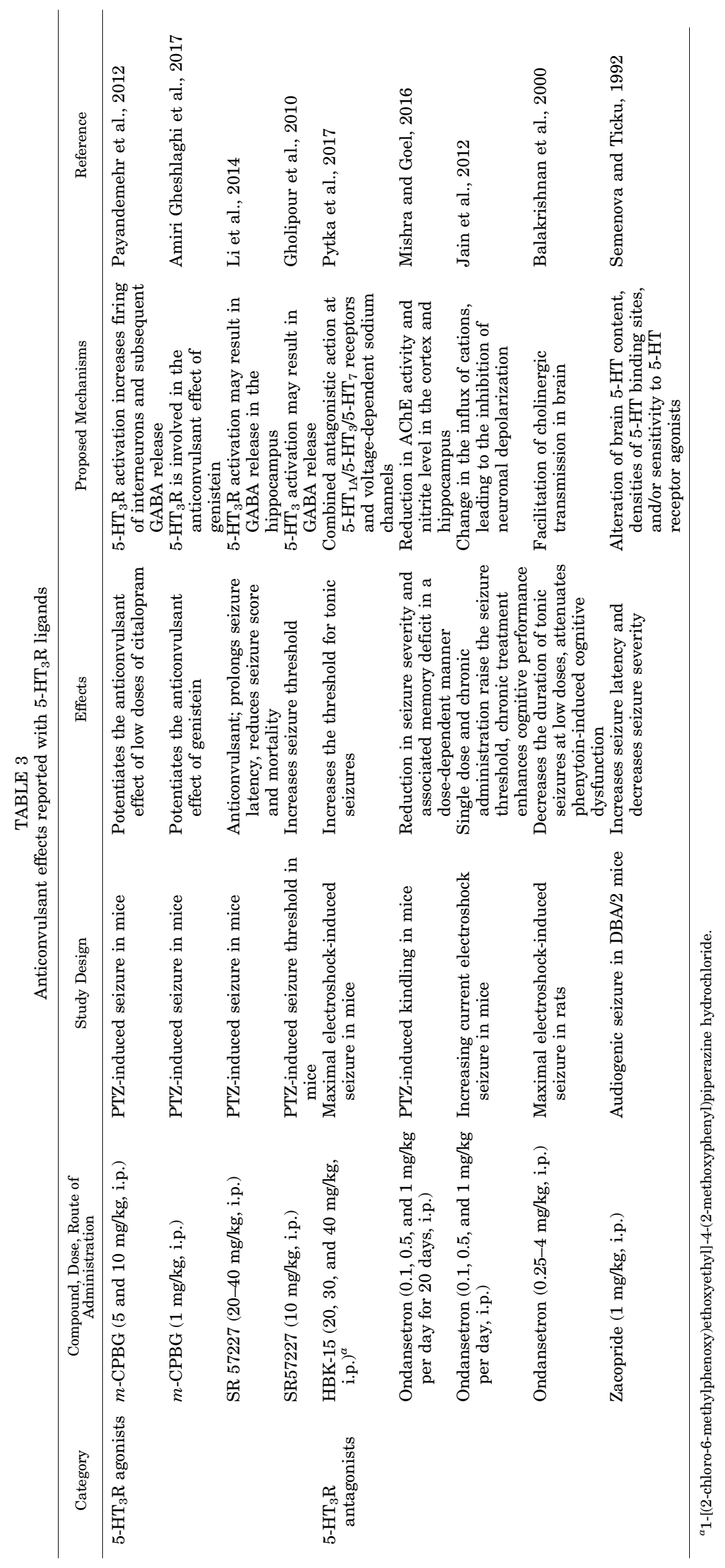


et al., 2000). In the amygdala kindling model of generalized seizures in rats, the 5 - $\mathrm{HT}_{3}$ agonist $m$-CPBG lowered the seizure threshold (Wada et al., 1997). In line with these observations, granisetron shortened the duration of primary after discharges, thereby attenuating hippocampal partial seizures evoked by low-frequency electrical stimulation. Interestingly, the effect was dose specific; the dose of $1 \mathrm{mg} / \mathrm{kg}$ was anticonvulsant, whereas the $0.3-$ or $3-\mathrm{mg} / \mathrm{kg}$ doses were ineffective, yielding a U-shaped dose-response curve (Watanabe et al., 2000). These findings are in contrast with a report showing a proconvulsant effect of $10 \mathrm{mg} / \mathrm{kg}$ granisetron in a mouse model of PTZ-induced seizure (Gholipour et al., 2010). Chronic treatment with ondansetron was recently shown to ameliorate seizures and associated memory deficit in PTZ-kindled mice. The memory improvement effects of ondansetron were accompanied by a decrease in nitrite level and AChE activity in the cortex as well as in the hippocampus of kindled mice. To our knowledge, this is the first report implying that anti-inflammatory aspects of ondansetron may be involved in anticonvulsant actions of a $5-\mathrm{HT}_{3} \mathrm{R}$ antagonist (Mishra and Goel, 2016). However, this apparent discrepancy might arise from a number of differences between the two studies, such as those in seizure models and animal species as well as in the doses of granisetron used, since bell-shaped dose-response curves have been described for select pharmacological actions of $5-\mathrm{HT}_{3}$ antagonists.

As detailed above, 5-HT and selective $5-\mathrm{HT}_{3}$ agonists can depolarize hippocampal interneurons, leading to hyperpolarization of CA1 pyramidal neurons. Adding to this, evidence suggests that stimulation of $5-\mathrm{HT}_{3} \mathrm{R}$ gives rise to elevations in intraneuronal calcium concentrations, which subsequently activates neuronal nitric oxide (NO) synthase and triggers NO production (Reiser, 1990). Given the epileptogenic role of NO in some seizure models (Osonoe et al., 1994; Riazi et al., 2006), it is possible that 5 - $\mathrm{HT}_{3}$ agonists simultaneously activate anticonvulsant and proconvulsant pathways in the hippocampus by stimulating inhibitory GABAergic interneurons and NO production, respectively. The ultimate outcome of $5-\mathrm{HT}_{3}$ activation may therefore depend on several factors, including the species studied, the seizure model applied, the nature and dose of the drug used in the study, and so on. This hypothesis is supported by the results of an experiment showing that the anticonvulsant effect of SR57227 is facilitated by coadministration with the NO synthase inhibitor $N \omega$-nitro-L-argininemethyl ester, whereas the NO precursor L-arginine potentiates the proconvulsant action of granisetron (Gholipour et al., 2010). Moreover, despite the selective expression of the majority of $5-\mathrm{HT}_{3} \mathrm{Rs}$ on inhibitory interneurons in the hippocampal CA1 region, a subgroup of these receptors are also found on pyramidal cells, the stimulation of which can potentially activate pyramidal neurons and increase their excitability (Tecott et al., 1993).

\section{B. Neurotoxicity Associated with Cancer Chemotherapy Drugs}

Sensory-motor neuropathy is a severe side effect of vincristine experienced by patients with cancer, the recovery from which is usually incomplete (Authier et al., 2003). The pathomechanisms underpinning this adverse event, as shown by in vitro and in vivo studies, include damage to Schwann cells and dorsal root ganglion neurons as a result of laminin depletion in Schwann cells and neurite retraction in the dorsal root ganglion (Konings et al., 1994a,b), as well as disruption in the normal process of myelination (Djaldetti et al., 1996). Damaged Schwann cells release inflammatory cytokines (Shamash et al., 2002; Thacker et al., 2007) and chemokines that trigger the cascades of chemotaxis (Tofaris et al., 2002; White et al., 2005) and neuroinflammation, resulting in neuropathic pain in the form of hyperalgesia and allodynia. Interestingly, tropisetron pretreatment successfully attenuated vincristine-related nerve injury in rats, as evidenced by a reduction in behavioral and electrophysiological scores as well as diminution of pathologic and morphometric changes (Barzegar-Fallah et al., 2014). Granisetron at the same dosage, however, did not affect any of the assessed parameters and coadministration of the selective 5- $\mathrm{HT}_{3}$ agonist $m$-CPBG failed to offset the beneficial effects seen with tropisetron (Barzegar-Fallah et al., 2014). These observations suggest a $5-\mathrm{HT}_{3} \mathrm{R}$-independent mechanism of action for tropisetron. At the molecular level, elevation of intracellular calcium after nerve injury activates calcineurin, which in turn dephosphorylates nuclear factor of activated $\mathrm{T}$ cells, leading to its nuclear translocation. Consequently, several cytokines, including interleukin (IL)-2, IL-4, and tumor necrosis factor- $\alpha$, are released and neuronal apoptosis ensues (Kantrow et al., 2000; Cai et al., 2013). Interestingly, tropisetron targets calcineurin as a central player in neuronal damage (Rahimian et al., 2011b) and, in keeping with the in vivo observation (Barzegar-Fallah et al., 2014), the inhibition of calcineurin phosphatase activity by tropisetron represents one plausible mode of action underlying the neuroprotective effects of this drug. Other mechanisms that potentially contribute to setrons' protection against vincristine-associated neuropathy could include their ability to activate $\alpha 7 \mathrm{nAChR}$ (Swartz et al., 2013; Fakhfouri et al., 2015; Callahan et al., 2017), induction of the anti-inflammatory transcriptional factor nuclear factor erythroid 2-related factor 2 and its downstream molecules heme oxygenase and catalase (Khalifeh et al., 2015), as well as inhibition of p38 MAPK (Liu et al., 2012; Stratz et al., 2012). Interventions that exert these effects have been shown to attenuate vincristineinduced neuropathy (Shen et al., 2015).

The potential indication of $5-\mathrm{HT}_{3} \mathrm{R}$ antagonists in counteracting chemotherapy-related neuropathy and 
neurotoxicity is of high clinical relevance, as a setron is already part of the antiemetic regimen administered to patients with cancer who receive vincristine.

\section{Central Component of Irritable Bowel Syndrome}

IBS is a chronic heterogeneous gastrointestinal disorder with uncertain pathophysiology. Nevertheless, a high prevalence of psychiatric comorbidities (Fond et al., 2014) along with abnormalities reported from structural and functional imaging studies of patients with IBS increasingly point to dysfunction of brain-gut interactions as an etiological factor in IBS (Fichna and Storr, 2012; Bonaz, 2013; Tsang et al., 2016). Brain imaging studies suggest a possible alteration in the activation of subregions in the anterior cingulate cortex and emotional motor system, including the amygdala, ventromedial PFC, periaqueductal gray matter, and locus coeruleus (LC), during colorectal stimulation (Mertz et al., 2000; Naliboff et al., 2001, 2003).

The cognitive-behavioral model of IBS in animals also lends more credibility to the theory (Greenwood-Van Meerveld et al., 2001). In this model, a substantial link has been shown between the central pathways and regions mediating stress and anxiety, especially the amygdala, and mechanisms regulating colonic sensitivity and motility (Tyler et al., 2007). In this context, 5-HT is a pivotal monoamine involved in the brain-gut connection and is the best-described neurotransmitter in IBS pathology. Among the 5-HT receptors, 5- $\mathrm{HT}_{3} \mathrm{Rs}$ stand out (Stasi et al., 2014). In fact, alosetron, a $5-\mathrm{HT}_{3} \mathrm{R}$ antagonist (Table 1 ), has shown effectiveness in treating diarrhea-predominant IBS. Alosetron alleviates abdominal discomfort and pain and improves stool consistency in both female and male patients, although its positive effects on sense of urgency, stool frequency, and bloating was only seen in female patients (Komoto and Miura, 2006). The mechanisms and sites underlying the therapeutic effect of alosetron in IBS are not completely understood. 5 - $\mathrm{HT}_{3} \mathrm{Rs}$ have been identified on peripheral terminals of spinal and vagal afferents, in the spinal cord, and at multiple supraspinal sites. The latter include nuclei in the dorsal pons (trigeminal motor nucleus), medulla (dorsal vagal complex), amygdala, hippocampus, ventral striatum, hypothalamus, and PFC (Fletcher and Barnes, 1999; Carrillo et al., 2010). In humans, the amygdala and dorsal vagal complex show the highest density of supraspinal $5-\mathrm{HT}_{3} \mathrm{Rs}$ (Mayer et al., 2002). Compared with placebo, 3 weeks of treatment with alosetron in nonconstipated patients with IBS decreased the activity of $5-\mathrm{HT}_{3} \mathrm{R}-$ containing regions of the emotional motor system, but not in areas activated by pain, in response to unanticipated, anticipated, and delivered aversive rectal stimuli. This was significantly correlated with improvement in gastrointestinal symptoms (Berman et al., 2002; Mayer et al., 2002).
Together, these results add grounds to the hypothesis that the CNS effects of $5-\mathrm{HT}_{3} \mathrm{R}$ antagonists play a significant role in counteracting the pathophysiology of this syndrome (Bonaz et al., 2002). Moreover, this class of drugs is also effective in alleviating CNS comorbidities of IBS such as anxiety and depression (discussed in corresponding subsections of section V.A and V.B).

\section{Memory Disorders}

Memory disorders can range from mild to severe, but they all result from some kind of neurologic damage of the brain, thus impeding the storage, retention, and recollection of memories. Memory disorders can be progressive, such as $\mathrm{AD}$, or immediate, such as those resulting from brain injury. Cognitive deficit is also an integral part of schizophrenia clinical manifestations (Green et al., 2004). ACh is a crucial neurotransmitter that regulates cognitive performance, learning, and memory processes. During aging, cholinergic neurons of the basal forebrain complex undergo degenerative changes that lead to cholinergic hypofunction (Schliebs and Arendt, 2006). Basal forebrain cholinergic cell loss is also a core feature of AD (Liu et al., 2015) and PD dementia (Perry et al., 1985). In experimental studies, $5 \mathrm{HT}_{3} \mathrm{R}$ antagonism can reverse learning and memory deficits invoked by scopolamine or lesions to the cholinergic nucleus basalis of Meynert (Barnes et al., 1990; Chugh et al., 1991; Carli et al., 1997; Ohno and Watanabe, 1997). Antagonism at $5 \mathrm{HT}_{3} \mathrm{R}$ also improved novel object recognition in aged monkeys (Arnsten et al., 1997) and aged rats (Callahan et al., 2017). As previously discussed, $5-\mathrm{HT}_{3} \mathrm{Rs}$ are highly expressed in the amygdala, hippocampus, and cortex, regions integral to memory processing (Gulyás et al., 1999; Thompson and Lummis, 2007; Walstab et al., 2010). The ability of the antagonists to enhance cholinergic neurotransmission in these regions (Maura et al., 1992; Diez-Ariza et al., 2002; Seyedabadi et al., 2014) can explain, in part, their procognitive actions.

Activation of $\alpha 7 \mathrm{nAChR}$ is another mode of action for memory-boosting properties of tropisetron (Callahan et al., 2017). This receptor has received considerable attention as a potential therapeutic target in $\mathrm{AD}$ and schizophrenia (for review, see Bertrand et al., 2015). The expression of $\alpha 7 \mathrm{nAChR}$ protein is markedly reduced in the $\mathrm{AD}$ cortex (Burghaus et al., 2000) and agonists of $\alpha 7 \mathrm{nAChRs}$ consistently improve various forms of cognitive performance in experimental studies (Levin et al., 1999; Boess et al., 2007) as well as in healthy volunteers (Kitagawa et al., 2003) and nonsmoking patients with schizophrenia (Olincy et al., 2006; Preskorn et al., 2014).

Tropisetron might provide an additional benefit in $\mathrm{AD}$. In an animal model of AD (J20 mice), low doses of tropisetron increased the soluble $\mathrm{APP} \alpha / \mathrm{A} \beta 1-42$ ratio, suggesting a favorable effect in ameliorating the $\mathrm{AD}$ pathology. This was accompanied by spatial and working 
memory enhancement in symptomatic, preplaque phase, and late plaque phase. Intriguingly, tropisetron was superior to $\mathrm{AD}$ therapeutic drugs memantine and donepezil in both the cognitive aspect and amyloidogenic process (Spilman et al., 2014; Hashimoto, 2015). Tropisetron also protected against $A \beta$-induced neuroinflammation in vivo through the calcineurin pathway (Rahimian et al., 2013b). Much is still unknown about the exact role of $5-\mathrm{HT}_{3} \mathrm{R}$ in dementia and $\mathrm{AD}$. It has been reported that fibrillar $\mathrm{A} \beta$ is neurotoxic through blockade of $\alpha 7 \mathrm{nAChRs,} \mathrm{whereas}$ oligomeric $\mathrm{A} \beta$ may oppositely activate $\alpha 7 \mathrm{nAChRs}$, leading to stimulation of protective downstream signaling cascades (Khan et al., 2010; Lilja et al., 2011). However, we do not know whether such an interaction exists for other ligand-gated ion channels such as $5-\mathrm{HT}_{3} \mathrm{R}$ and, if so, in which direction $\mathrm{A} \beta$ may affect the signaling of this receptor.

Another mediator that can account for setroninduced memory improvement is NO. NO is a crucial neuromodulator involved in memory through synaptic plasticity in various brain areas such as the hippocampus (Susswein et al., 2004; Javadi-Paydar et al., 2012), and the inhibition of NO synthesis impairs spatial memory in small rodents (Tanaka et al., 2009). Facilitation of the NO pathway has been reported to contribute to the ability of granisetron to improve spatial recognition memory in scopolamine-induced memory-impaired mice (Javadi-Paydar et al., 2012).

In addition to facilitation of cholinergic transmission and NO signaling, $5-\mathrm{HT}_{3} \mathrm{R}$ antagonists can rescue cognition through various mechanisms, including antiinflammatory effects (e.g., inhibition of nuclear factor$\kappa \mathrm{B})$, induction of peroxisome proliferator-activated receptor $\gamma(\operatorname{PPAR} \gamma)$ transcriptional activity (see section IV.F), and attenuation of calcium signaling (Rahimian et al., 2013b, 2016). Therefore, they hold great promise as a new therapeutic approach for memory impairments with complex etiopathology such as $\mathrm{AD}$ (for more details, see Fakhfouri et al., 2012, 2015). This potential is clinically relevant since U.S. Food and Drug Administration-approved memory-improving drugs such as cholinesterase inhibitors and memantine are not universally effective in patients with dementia (Raina et al., 2008) and $\mathrm{AD}$ (Schneider et al., 2011). Tropisetron has advanced into clinical trials for enhancing cognitive function in $\mathrm{AD}$ and schizophrenia (Bertrand et al., 2015).

\section{E. Inner Ear Diseases}

Dysfunction of the inner ear causes vertigo, hearing loss, and tinnitus in patients, leading to physical and functional impairment that is further associated with anxiety, social isolation, and cognitive decline (Jacob and Furman, 2001; Lin et al., 2011a; Bisdorff et al., 2013; Contrera et al., 2017; Kim et al., 2018). A number of pathologies, such as vestibular neuritis and sudden sensorineural hearing loss, have acute onset and lead to permanent impairments of inner ear function (Kuhn et al., 2011; Manzari et al., 2013) through degeneration of the sensory epithelium, primary nerves, and their synaptic connections, as documented in postmortem tissue samples from patients (Rauch, 2001; Merchant et al., 2005; Richard and Linthicum, 2012). In most cases, the etiology remains undetermined, although viral infections and cardiovascular causes have been speculated for both vestibular and cochlear sudden impairments (Strupp and Brandt, 2009; Chau et al., 2010; Linthicum et al., 2013; Manzari et al., 2013). After the acute episode of vestibular neuritis, up to approximately $50 \%$ of patients have permanent unilateral loss of function documented up to 10 years later (Strupp and Brandt, 2009), and more than $60 \%$ of patients suffer deficits with associated physical and functional handicaps 5 years after onset (Mandalà and Nuti, 2009). Sudden sensorineural hearing loss leads to permanent hearing impairment in 35\%-68\% of patients as measured with standard audiograms; even in the absence of hearing threshold deficits, patients can experience communication difficulties and tinnitus after an acute inner ear lesion (Schreiber et al., 2010; Spankovich et al., 2017). No registered pharmacological treatment currently exists for these acute-onset conditions, and current therapy primarily consists of off-label use of corticosteroids (Brandt et al., 2009; Walker, 2009; Stachler et al., 2012), although meta-analysis and systematic reviews have failed to demonstrate a significant treatment effect (Goudakos et al., 2010; Crane et al., 2015).

A small clinical pilot study conducted by Venail et al. (2012) demonstrated that patients with vestibular neuritis who received antiemetic treatment with ondansetron instead of the standard antiemetic metoclopramide recovered faster and exhibited reduced lasting vestibular dysfunction. Specifically, patients taking ondansetron demonstrated shorter time until first unassisted walk, reduced duration of hospitalization, and reduced vestibular deficits measured by caloric testing.

To further investigate the potential for a diseasemodifying treatment effect of $5-\mathrm{HT}_{3} \mathrm{R}$ antagonists in inner ear disease, an animal model of vestibular excitotoxic synaptic insult was implemented in female Long-Evans rats (Dyhrfjeld-Johnsen et al., 2013). To mimic the clinical situation as closely as possible, treatment with ondansetron was initiated after initial lesion induction. The preclinical study closely reproduced the clinical pilot study findings, demonstrating reduced functional impairment using behavioral scoring and reduced vestibular deficit as characterized by spontaneous nystagmus frequency measured with infrared video nystagmography equipment. Furthermore, the histologic comparison of tissue from ondansetron- and placebo-treated animals demonstrated preservation and accelerated recovery of afferent synapses between sensory hair cells and primary sensory neurons as the basis of the functional treatment effect. Loss of synaptic connections 
by excitotoxically mediated insults in the inner ear has been demonstrated to lead to long-term degeneration of primary afferent neurons (Kujawa and Liberman, 2009; Lin et al., 2011b), reminiscent of postmortem histologic findings from patients (Rauch, 2001; Merchant et al., 2005; Richard and Linthicum, 2012). Further experiments demonstrated that not only ondansetron but also other calcineurin-inhibiting 5 - $\mathrm{HT}_{3}$ antagonists such as tropisetron and azasetron effectively protected against kainate-induced synaptic loss in this animal model.

Subsequently, a number of $5-\mathrm{HT}_{3}$ antagonists were tested at equimolar daily doses in a rat model of sudden sensorineural hearing loss induced by acute acoustic trauma, one of the few well established etiologies of this condition (Dyhrfjeld-Johnsen, 2016). This model involves not only excitotoxic decoupling of afferent synapses as in the vestibular unilateral lesion model but also loss of sensory hair cells through oxidative stress and apoptosis induced by acoustic overstimulation (Yamashita et al., 2004; Yang et al., 2004; Parham and Dyhrfjeld-Johnsen, 2016). Daily intraperitoneal treatment with azasetron for 14 days, but not with other setrons, after 2 hours of exposure to intense 120 -dB octave noise significantly reduced hearing loss and increased survival of sensory hair cells. Azasetron is a chiral molecule with two enantiomers, $R$ and $S$, and additional experimentation demonstrated that the $R$ enantiomer was significantly more effective in treating acoustic trauma-induced sudden sensorineural hearing loss, due to significantly higher levels of drug exposure of $R$-azasetron in the inner ear after oral administration than for the racemic mixture or the isolated $S$-enantiomer (Dyhrfjeld-Johnsen, 2017). Further animal studies have shown that $R$-azasetron is equally effective in protecting from hearing loss and sensory cell death induced by administration of the chemotherapeutic drug cisplatin, another well known etiology of sensorineural hearing loss and debilitating treatment-related side effects for patients with cancer (Petremann et al., 2017).

The findings summarized here clearly underline the potential use of specific $5-\mathrm{HT}_{3}$ antagonists in the treatment of inner ear diseases. However, the experimental results discussed also highlight the complexity of setron family pharmacology and pharmacokinetics, emphasizing the need to take into account specific characteristics of these compounds as well the translational relevance of animal models.

Multiple studies have highlighted the potential neuroprotective properties of ondansetron and tropisetron (Rahimian et al., 2011a, 2013b; Venail et al., 2012; Aminian et al., 2013; Dyhrfjeld-Johnsen et al., 2013; Swartz et al., 2013), consistent with their capacity for inhibiting the protein phosphatase calcineurin-involved neurodegenerative cascades (de la Vega et al., 2005; Rahimian et al., 2011b). These results with $R$-azasetron are consistent with a neuroprotective effect through calcineurin inhibition (Dyhrfjeld-Johnsen, 2016, 2017;
Petremann et al., 2017), as is the lack of a protective effect for granisetron since this setron does not inhibit calcineurin (de la Vega et al., 2005; Rahimian et al., $2011 b)$. The contradictory lack of the protective effect of calcineurin-inhibiting setrons ondansetron and tropisetron against acoustic trauma could be explained through another aspect of their complex pharmacology, namely the reduction of ACh-mediated inhibition of inner ear sensory hair cells through antagonism of $\alpha 9 \alpha 10$ nAChR channels (Rothlin et al., 2003). Although calcineurin inhibition by ondansetron and tropisetron could in principle be neuroprotective, their disinhibition of already stressed inner ear sensorineural cells through significant $\alpha 9 \alpha 10 \mathrm{nAChR}$ antagonism would contribute to further depolarization, excitotoxicity, and calcium influx, canceling out neuroprotective properties and potentially even driving the balance toward neurodegeneration and cell death. In regard to druginduced toxicity by chemotherapy agents such as cisplatin, ondansetron has been shown to increase nephrotoxicity in animal models through inhibition of the multidrug and toxin extrusion transporter family (Li et al., 2013). Because multidrug and toxin extrusion transporters are also expressed in the inner ear (Gaboyard-Niay, 2013), inhibition of toxin extrusion transporters could equally contribute to enhanced ototoxicity resulting in worsening of hearing and balance.

In conclusion, the neuroprotective potential of $5-\mathrm{HT}_{3}$ antagonists is highly interesting for inner ear pathologies; however, the complex pharmacology and pharmacokinetic properties of the setron family compounds must be taken into account in a tissue- and diseasespecific manner, with respect to the potential selection of candidates for drug development. $R$-Azasetron has successfully completed the clinical phase I stage and is currently in development for use in protection against sudden sensorineural hearing loss and prevention of platinum-induced ototoxicity, based on its unique drug candidate profile combining neuroprotective calcineurin inhibition and high local target exposure in the apparent absence of deleterious disinhibition of sensory hair cells or modulation of transporters augmenting ototoxicity. This makes $R$-azasetron ideally suited for treating lesions of the inner ear, where exact etiology and involvement of cochlear and vestibular substructures cannot be clearly distinguished based on current diagnostic testing of functional deficits.

\section{F. Stroke}

Stroke is a leading cause of death and long-term disability worldwide. Development of an effective therapeutic strategy for stroke has been a priority of neuroscience research for decades. To date, the results of several clinical trials for pharmacotherapy of stroke have been frustrating, with recombinant tissue plasminogen activators as the only agents approved by the U.S. Food and Drug Administration. Elucidation of novel cellular 
and molecular pathways that influence the pathogenesis of stroke could lead to the development of new therapeutic approaches (Kriz and Lalancette-Hébert, 2009; Lee et al., 2014). The first set of studies with $5-\mathrm{HT}_{3} \mathrm{R}$ antagonists indicated that these agents lack any beneficial effect in the transient middle cerebral artery occlusion model of stroke (Candelario-Jalil et al., 2008). On the other hand, $5-\mathrm{HT}_{3} \mathrm{R}$ antagonists display neuroprotective properties in vitro and in vivo. In fact, oxidative stress-induced injury in rat cortical neurons was counteracted through curtailing caspase-3 activation, calcium influx, reactive oxygen species generation, and excitotoxicity. The observed protection was shown to be mediated through blockade of $5-\mathrm{HT}_{3} \mathrm{Rs}$ by means of employing selective $5-\mathrm{HT}_{3} \mathrm{R}$ agonists (Lee et al., 2005b). In rat hippocampal slices, stimulation of $5-\mathrm{HT}_{3} \mathrm{R}$ exacerbated the ischemia-induced decrease in CA1 field potential, whereas antagonism of 5- $\mathrm{HT}_{3} \mathrm{R}$ produced dose-dependent neuroprotection against the ischemia-induced neuronal injury (Kagami et al., 1992). In vivo, tropisetron was also found to be beneficial in an embolic model of stroke (Rahimian et al., 2011a).

1. Modulation of Molecular Pathways. Different signaling pathways might explain the neuroprotective aspects of $5-\mathrm{HT}_{3} \mathrm{R}$ antagonists after ischemic insults. The first, as discussed earlier, is the calcineurin pathway. Briefly, $5-\mathrm{HT}_{3} \mathrm{R}$ antagonists inhibit aberrant calcineurin phosphatase activity via receptor-dependent and independent mechanisms, culminating in poststroke neuroprotection (Rahimian et al., 2011a,b). The second is activation of $\alpha 7 \mathrm{nAChR}$, an essential mediator of the cholinergic anti-inflammatory pathway (Kohnomi et al., 2010; Stegemann et al., 2013). In addition to neurons, $\alpha 7$ $\mathrm{nAChR}$ is expressed on a wide spectrum of immune cells, and its activation is shown to inhibit proinflammatory cytokine production from macrophages and microglia, adhesion molecule expression, and T-cell proliferation. In vivo, $\alpha 7 \mathrm{nAChR}$ stimulation effectively attenuates immune responses and ameliorates disease severity in various experimental settings. Activation of phosphoinositide 3-kinase/Akt (Rehani et al., 2008) and Janus kinase/signal transducer and activator of transcription 3 (Yu et al., 2009) cascades is implicated in the anti-inflammatory actions of $\alpha 7 \mathrm{nAChR}$ (Fig. 1). Activation of this pathway, however, can only explain the neuroprotective properties of tropisetron, as other congeners do not affect $\alpha 7 \mathrm{nAChR}$. The third plausible mechanism is potentiation of endocannabinoid-mediated anti-inflammatory signaling in the CNS, which is also confined to tropisetron. Indeed, tropisetron upregulates cannabinoid type 1 receptor $\left(\mathrm{CB}_{1} \mathrm{R}\right)$ expression at both transcriptional and translational levels in cultured cerebellar granule neurons. This effect is accompanied by a decrease in the $\mathrm{CB}_{1} \mathrm{R}$ secondary messenger, cAMP. Intriguingly, treatment of cerebellar granule neurons with granisetron did not affect the expression of $\mathrm{CB}_{1} \mathrm{R}$ or its function (Rahimian et al., 2011b). Finally, the last possible mechanism, which corroborates the neuroprotective profile of setrons, is PPAR $\gamma$ activation. Tropisetron attenuates gut inflammation through PPAR $\gamma$ induction after rectal acetic acid instillation. The protective effect is diminished in the presence of PPAR $\gamma$ receptor antagonist GW9662 (Rahimian et al., 2016). The same mechanism could underpin the action of $5-\mathrm{HT}_{3} \mathrm{R}$ antagonists in cerebral ischemia models, since the PPAR $\gamma$ agonist pioglitazone leads to a prominent improvement in transient middle cerebral artery occlusion in rats (Deplanque et al., 2003; Shimazu et al., 2005; Sundararajan et al., 2005; Bordet et al., 2006a). However, it is currently unknown whether the induction of PPAR $\gamma$ transcriptional activity is receptor mediated or through direct interaction with PPAR $\gamma$.

2. Possible Effects on Microglia. Microglia respond dynamically to ischemic injury, experiencing both proand anti-inflammatory phenotypes. These dual and opposing roles of microglia suggest that stroke therapies should be shifted from simply suppressing microglia toward adjusting the balance between beneficial and detrimental microglia/macrophage responses (Rahimian et al., 2018, 2019). Some studies indicate that increased transcriptional activity of PPAR $\gamma$ can promote alternative microglia activation (Bordet et al., 2006b; Patel et al., 2013). Changing the microglia polarization could be an important mechanism by which $5-\mathrm{HT}_{3} \mathrm{R}$ antagonists elicit protective effects after brain ischemia. Tropisetron-induced microglia polarization could have notable clinical significance. Microglia constitutes self-renewing and long-lived resident macrophage-like cells of the brain. Although the precise roles of microglia in neuroinflammation have not been yet fully deciphered, recent studies strongly suggest their various essential functions in neurodegenerative contexts where they can act as a double-edged sword. Microglia phagocytose tissue debris and secrete proinflammatory cytokines, ensuing further damage (Patel et al., 2013). In contrast, they can also secrete antiinflammatory mediators to alleviate inflammation.

Stroke has a complex pathology and many different cells, including neurons, microglia, and astrocytes, are involved in the pathogenesis of stroke. Some studies have reported neuroprotective effects for $5-\mathrm{HT}_{3} \mathrm{R}$ antagonists both in vitro and in vivo, and various $5-\mathrm{HT}_{3} \mathrm{R}-$ dependent and $5-\mathrm{HT}_{3} \mathrm{R}$-independent mechanisms have been proposed. $5-\mathrm{HT}_{3} \mathrm{R}$ antagonists might affect the phenotype and polarization of nonneural populations such as microglia after stroke. Given that these cells do not express functional 5- $\mathrm{HT}_{3} \mathrm{Rs}$ (Krabbe et al., 2012), other serotonin-independent mechanisms such as regulation of intracellular pathways through modulation of other cell surface receptors or directly engagement with intracellular targets might be involved in the effects of setrons on glia. Yu et al. (2018) showed that tropisetron curtails microglial activation and therefore attenuated lipopolysaccharide (LPS)-induced neuroinflammation 
in the cerebral cortex by targeting the neuronal population, a mechanism previously reported for other setrons in colonic inflammation (Utsumi et al., 2016). Tropisetron, by antagonizing $5-\mathrm{HT}_{3} \mathrm{R}$ on neurons, diminishes substance $P$ release from nerve endings onto the neurokinin 1 receptor on microglia. The resultant decrease in nuclear factor $-\kappa \mathrm{B}$ activity downstream of neurokinin 1 receptor stimulation leads to less production of proinflammatory cytokines in the cortex and a milder neuroinflammatory phenotype (Yu et al., 2018).

Although the $5-\mathrm{HT}_{3} \mathrm{R}$ subtype is not expressed by microglia (Krabbe et al., 2012), many of the findings in vivo with the setron family (mostly tropisetron) imply a microglial component in their effects. This might stem from a crosstalk between $5-\mathrm{HT}_{3} \mathrm{R}$-expressing cell populations and microglia and/or from engagement of other targets of tropisetron expressed by microglia. Other possible mechanisms underlying setron-induced microglial alternative activation could rely on other types of membrane receptors such as nicotinic receptors or intracellular targets such as calcineurin, MAPK, and PPAR $\gamma$.

3. Effect on Diabetes and Glucose Intolerance as Risk Factors for Stroke. The role of $5-\mathrm{HT}_{3} \mathrm{R}$ has been investigated in glucose metabolism and pathogenesis of diabetes in vivo and in vitro. Central $5-\mathrm{HT}_{3} \mathrm{R}$ stimulation by $m$-CPBG has been shown to increase blood glucose in stressed rats and this effect is surmountable by administration of the $5-\mathrm{HT}_{3} \mathrm{R}$ antagonist ondansetron (Carvalho et al., 2002). Another report indicates that functional integrity of the brain corticotropin-releasing hormone $(\mathrm{CRH})$ system and $5-\mathrm{HT}_{3} \mathrm{Rs}$ is needed for serotonergic agonist-induced hyperglycemia (Carvalho et al., 2002, 2005; Fakhfouri et al., 2012). In vitro, $5-\mathrm{HT}_{3} \mathrm{R}$ antagonists were found to enhance insulin release by INS-1 cells. The effect was interestingly more pronounced in the presence of serotonin. Serotonin reduced the glucose-stimulated release of insulin in a concentration-dependent manner, whereas tropisetron abolished this inhibition (Heimes et al., 2009). Such

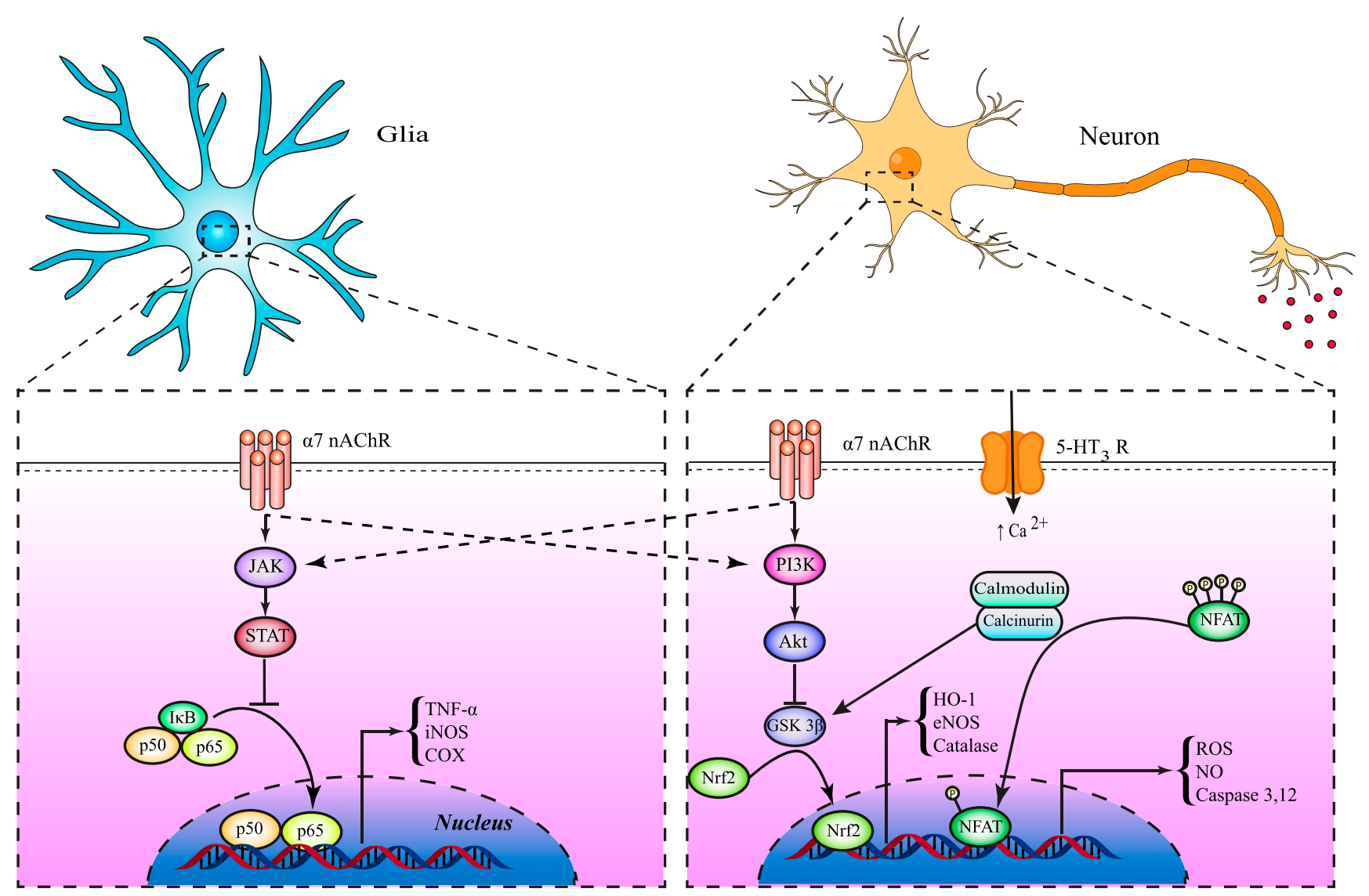

Fig. 1. Impact of 5-HT3R antagonists on the molecular pathways within different cell populations in the brain. Neural blockade by setrons of 5 -HT ${ }_{3} R$ exerts neuroprotection by diminishing calcium influx and subsequent inhibition of the calcium-sensitive phosphatase calcineurin. The latter controls the activation status of transcriptional factors such as NFAT. Such inhibition affects the expression of proteins involved in survival and inflammation. Moreover, activation of $7 \alpha \mathrm{nAChR}$ in neurons and glia by tropisetron triggers anti-inflammatory cascades, including JAK/STAT and PI3K/Akt, which potentiate the activity of transcriptional factor Nrf2 and its downstream pathways (HO-1 and CAT), and inhibits the canonical proinflammatory protein $\mathrm{NF}_{\kappa} \mathrm{B}$, which governs the production of proinflammatory cytokines (e.g., TNF- $\alpha$ ) and enzymes (e.g., iNOS and COX-2) involved in neuroinflammation. Solid arrows indicate activation, blind-ended arrows indicate inhibition, and dashed arrows indicate activation of the target pathways in both cell types. CAT, catalase; COX-2, cyclooxygenase-2; eNOS, endothelial nitric oxide synthase; GSK3 $\beta$, glycogen synthase kinase 3; HO-1, heme oxygenase-1; iNOS, inducible nitric oxide synthase; JAK, Janus kinase; NFAT, nuclear factor of activated T cells; NF $\kappa$ B, nuclear factor $\kappa$ B; Nrf2, nuclear factor erythroid 2-related factor 2; PI3K, phosphoinositide 3-kinase; ROS, reactive oxygen species; STAT, signal transducer and activator of transcription; TNF- $\alpha$, tumor necrosis factor $\alpha$. 
observation points out the involvement of $5-\mathrm{HT}_{3} \mathrm{Rs}$ in tropisetron-induced insulin secretion. In vivo, tropisetron has been shown to induce PPAR $\gamma$ transcriptional activity and to be beneficial in cerulein-induced acute pancreatitis in mice (Rahimian et al., 2016, 2017). These effects highlight the ability of $5-\mathrm{HT}_{3} \mathrm{R}$ antagonists in regulating blood glucose levels. Since glucose intolerance and diabetes constitute one of the most important risk factors for ischemic stroke (Olsson et al., 1990), $5-\mathrm{HT}_{3} \mathrm{R}$ antagonists have the potential to be investigated in this subset of patients. Their anti-inflammatory and memoryenhancing effects, alongside their positive effects in balancing blood glucose levels, make them a potential candidate to rescue brain damage after stroke (Rahimian et al., 2013a).

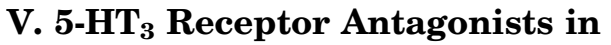 Psychiatric Disorders}

$5-\mathrm{HT}_{3} \mathrm{Rs}$ are implicated in emotion- and cognitiongoverning neural processes and antagonists of these receptors are shown to be beneficial in the treatment of various psychiatric disorders (Hammer et al., 2012).

\section{A. Depression}

Major depressive disorder is a common psychiatric disorder typified by persistent low mood, cognitive impairment, volitional decline, and somatic symptoms (Cai et al., 2015). Despite the availability of various classes of antidepressants, treatment of depression is hampered by insufficient and nonuniversal efficacy as well as untreated or residual cognitive impairment, warranting newer alternatives. $5-\mathrm{HT}_{3} \mathrm{R}$ antagonists stand out as a good candidate.

Various ligands with antagonistic activity at $5-\mathrm{HT}_{3} \mathrm{R}$ acutely reduce immobility time in the forced swim test (FST) (Mastorakos et al., 1993) and tail suspension test (Gupta et al., 2014b). In addition, tropisetron, zacopride, and ondansetron abolish learned helplessness in rats when administered on a chronic schedule, suggesting a class effect (Martin et al., 1992). In chronic depression models rendered either by exposure to chronic unpredictable stress or repeated corticosterone administration, $5-\mathrm{HT}_{3} \mathrm{R}$ antagonists reverse depressive behavior in mice (Gupta et al., 2014a,b, 2015).

1. Modulation of Putative Neuropathology. Many of the neuropathologic mechanisms associated with major depressive disorder appear to be modulated by $5-\mathrm{HT}_{3} \mathrm{Rs}$ and their antagonists. This might distinctly underpin the acute and chronic antidepressant-like actions of $5-\mathrm{HT}_{3}$ antagonists repeatedly reported in diverse animal models. The LC, the main nucleus for norepinephrine (NE) synthesis, receives a dense innervation from the 5-HT-producing dorsal raphe nucleus (DRN) (Levitt and Moore, 1978). Stimulation of this serotonergic projection curtails activity of noradrenergic neurons in the LC (Segal, 1979). Using dual-probe microdialysis in awake rats and electrophysiological techniques on brainstem sections, Ortega et al. (2012) demonstrated that activation of $5-\mathrm{HT}_{3} \mathrm{R}$ stimulates $\mathrm{NE}$ release in the LC, which induces sequentially a decrease in the firing rate of LC neurons through $\alpha 2$ adrenergic autoreceptors and a decrease of NE release in terminal areas such as the PFC. Therefore, the NE-depleted PFC of patients with depression could be hypothetically replenished by prescription of $5 \mathrm{HT}_{3} \mathrm{R}$ antagonists.

5 - $\mathrm{HT}_{3} \mathrm{Rs}$ expressed on a subset of GABAergic interneurons in the hippocampus and $\mathrm{PFC}$ serve as regulators of GABA release and therefore glutamatergic transmission by 5-HT (Puig et al., 2004). Electrophysiological studies demonstrate that stimulation of 5 - $\mathrm{HT}_{3} \mathrm{R}$ inhibits both the spontaneous and $N$-methylD-aspartate-induced firing of pyramidal neurons in the rat medial PFC (Ashby et al., 1991; Liang et al., 1998). In line with this, pharmacological blockade of $5-\mathrm{HT}_{3} \mathrm{R}$ increases the firing activity of glutamatergic pyramidal cells via disinhibition (Reznic and Staubli, 1997) (Fig. 2).

Vortioxetine provides further evidence for the engagement of $5-\mathrm{HT}_{3} \mathrm{R}$ ligands in the modulation of neurotransmitter release and antidepressant activity. This multimodal agent combines the SSRI mode of action (i.e., inhibition of the serotonin transporter) with $5-\mathrm{HT}_{3} \mathrm{R}$ antagonism to augment 5 - $\mathrm{HT}$ availability in synapses (Stahl, 2015). The latter most likely contributes to vortioxetine's clinical antidepressant effects (Pehrson and Sanchez, 2014; Sanchez et al., 2015). The blockade of $5-\mathrm{HT}_{3} \mathrm{R}$ by vortioxetine disinhibits pyramidal neurons through elimination of GABAergic inhibition. The resultant increase in glutamatergic transmission stimulates serotonergic neurons in the raphe nucleus to release 5-HT (Stahl, 2015). Similarly, ondansetron demonstrates synergistic antidepressantlike effects in the FST when used as an adjunct to SSRIs (Redrobe and Bourin, 1997; Bétry et al., 2015). The effect is most likely due to the enhancement of SSRI action on extracellular 5 -HT through $5-\mathrm{HT}_{3} \mathrm{R}$ blockade.

Anhedonia has been linked with disruptions in the mesolimbic DA circuit (Nestler and Carlezon, 2006). Although neurochemical studies generally fail to support a role for $5-\mathrm{HT}_{3} \mathrm{R}$ in mesolimbic $\mathrm{DA}$ release under basal conditions (Koulu et al., 1989; Invernizzi et al., 1995), phasic DA cell firing and transmission consistently show positive modulation by $5-\mathrm{HT}_{3} \mathrm{R}$ in both the NAc and VTA (Campbell et al., 1996; De Deurwaerdère et al., 1998). Thus, $5-\mathrm{HT}_{3} \mathrm{R}$ antagonists inhibit drugevoked/altered DA release in the mesolimbic pathway presumably via a presynaptic mechanism (Chen et al., 1991). The translatability of the electrophysiological and biochemical observations in anhedonia was assessed by a study using the chronic unpredictable stress-evoked depression model. In this setting, prolonged administration of ondansetron at doses as low as $0.05 \mathrm{mg} / \mathrm{kg}$ to mice with an established depressive 
phenotype was sufficient to reduce floating time in the FST and increased consumption of sucrose in the sucrose preference test. The effect mirrored that of antidepressant fluoxetine and was accompanied by correction of the hyperactive hypothalamic-pituitary-adrenal (HPA) axis, as revealed by normalization of elevated plasma corticosterone levels (Gupta et al., 2014a). Corroborating to the observed effect of $5-\mathrm{HT}_{3} \mathrm{R}$ antagonism on the HPA axis, mice lacking $5 \mathrm{HT}_{3 \mathrm{~A}}$ exhibited dampened adrenocorticotropic hormone responses to acute stressors, including LPS and restraint, with no change in pituitary sensitivity to CRH (Bhatnagar et al., 2004). The effects of $5-\mathrm{HT}_{3} \mathrm{R}$ antagonists on neuronal networks are summarized in Fig. 2.

Regarding the presence of an inflammatory milieu in depression (Cai et al., 2015), setrons can foster benefit owing to their anti-inflammatory properties as substantiated in peripheral inflammatory conditions (Stratz et al., 2002; Tolk et al., 2004; Müller et al., 2006). In vitro, tropisetron and ondansetron exhibit antiinflammatory effects on LPS-challenged human monocytes by specifically inhibiting tumor necrosis factor- $\alpha$ and IL- $1 \beta$ secretion while minimally affecting other cytokines or chemokines (Fiebich et al., 2004a). The effect is exerted at the posttranscriptional level and presumably mediated by inhibiting the activating phosphorylation of p38 MAPK (Stratz et al., 2012).

As stated in section IV.F, $5-\mathrm{HT}_{3} \mathrm{R}$ antagonism can induce PPAR $y$ transcriptional activity (Rahimian et al., 2016). This effect has an established antidepressive outcome in both animal and human studies (Eissa Ahmed et al., 2009; Sepanjnia et al., 2012).

2. Pharmacological Action of Antidepressants on 5-HT $\mathrm{H}_{3}$ Receptors. $5-\mathrm{HT}_{3} \mathrm{Rs}$ might constitute a site of action for prescribed antidepressants. In 1994, for the first time, the prototypes of three different classes of these agents were shown to block inward currents mediated by endogenous $5-\mathrm{HT}_{3} \mathrm{Rs}$ on primary rat nodose ganglion neurons (Fan, 1994). In patch-clamp recordings, the tricyclic antidepressant (TCA) imipramine (which inhibits reuptake of both $\mathrm{NE}$ and 5-HT), the SSRI fluoxetine, and monoamine oxidase inhibitors phenelzine and iproniazid markedly inhibited cation peak current and accelerated desensitization of $5-\mathrm{HT}_{3}$ channels. The functional antagonism appears to result from a direct action on $5-\mathrm{HT}_{3} \mathrm{Rs}$ rather than engaging secondary messengers, since intercellular application of either general protein kinase inhibitors or a calcium chelator failed to alter the effects of any antidepressant on 5 - $\mathrm{HT}_{3}$ current kinetics (Fan, 1994).

A decade later, this list was complemented with antidepressants from newer categories. In fact, reboxetine, an $\mathrm{NE}$ reuptake inhibitor, and mirtazapine, an atypical antidepressant with noradrenergic and specific serotonergic activity, as well as first- and second-generation TCAs proved potent inhibitors of 5-HT-evoked calcium and sodium currents at therapeutically relevant concentrations. The currents were measured at recombinant $5-\mathrm{HT}_{3 \mathrm{~A}}$ receptors on human embryonic kidney 293 cells and endogenous $5-\mathrm{HT}_{3} \mathrm{Rs}$ on murine primary and immortal neurons (Eisensamer et al., 2003). The noncompetitive nature of blockade exhibited by all antidepressants but mirtazapine suggests the involvement of an interaction site distinct from the agonist binding site, leading to an allosteric modulation of this ligand-gated ion channel by antidepressants (see the section II.C).

In summary, antidepressants possess a similar profile on $5-\mathrm{HT}_{3} \mathrm{R}$ current kinetics despite disparate molecular structures and distinct putative mechanisms of action. In addition, $5-\mathrm{HT}_{3} \mathrm{R}$ antagonists

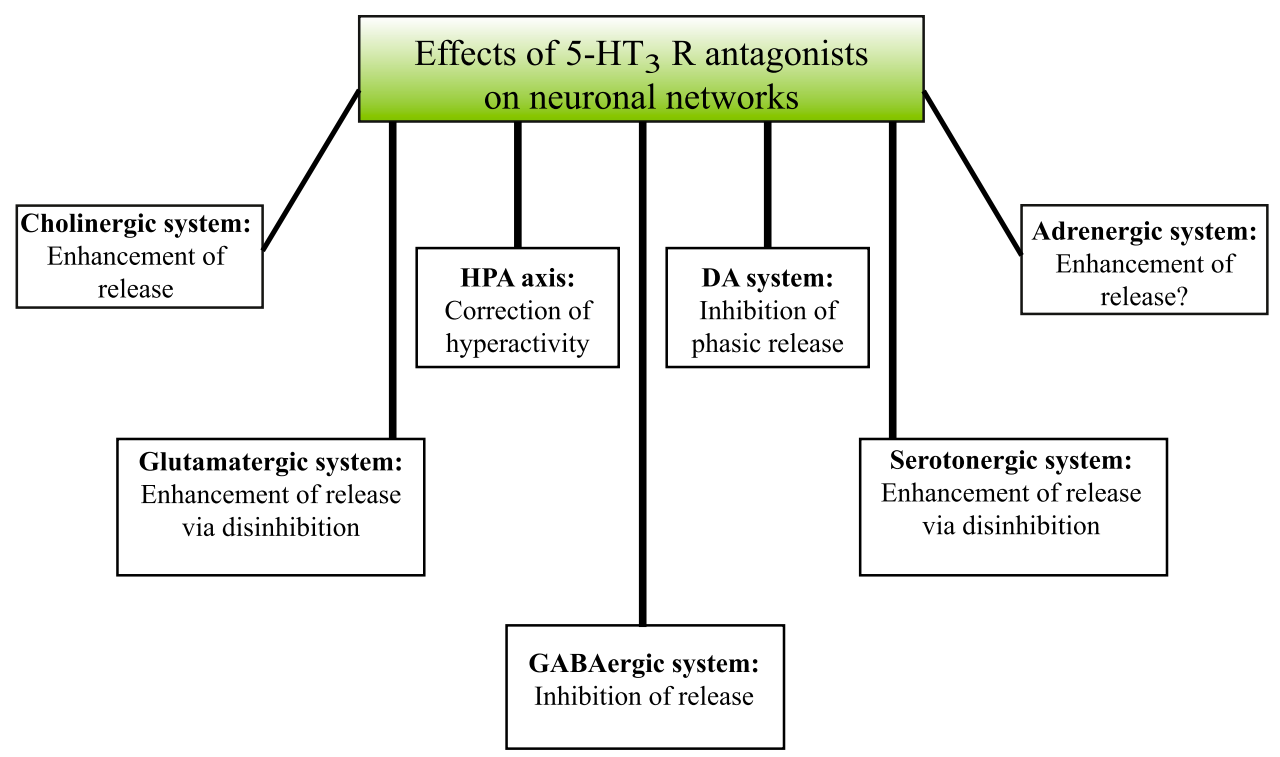

Fig. 2. Effects of $5 \mathrm{HT}_{3} \mathrm{R}$ antagonists on neurotransmitter systems and the HPA axis. 
display antidepressant activity in various preclinical settings. Therefore, it is plausible that $5-\mathrm{HT}_{3} \mathrm{Rs}$ serve as a yet unappreciated target of antidepressant action and antagonism of this ion channel receptor can emerge as a novel strategy toward an effective and more selective pharmacotherapy. In conformity with this notion, the TCA-induced decreased duration of immobility of mice in the FST is also reversed by $m$-CPBG, a $5-\mathrm{HT}_{3} \mathrm{R}$ agonist (Nakagawa et al., 1998).

3. Human Genetic Findings. In genetic studies, the high-frequency polymorphism encoding the Y129S variant in the $5-\mathrm{HT}_{3} \mathrm{~B}$ subunit was shown to be inversely correlated with the incidence of major depression in women (Yamada et al., 2006). Importantly, human heteromeric $5-\mathrm{HT}_{3 \mathrm{AB}}$ receptors containing the $\mathrm{Y} 129 \mathrm{~S}$ variant display unaltered surface expression levels but altered functional properties (Walstab et al., 2008), including a dramatically augmented maximal response to serotonin and slower desensitization and deactivation kinetics (Krzywkowski et al., 2008). This profile suggests that increased $5-\mathrm{HT}_{3 \mathrm{AB}}$ receptor-mediated neurotransmission of serotonin may controversially confer protection against the development of major depression in females.

For dedicated reviews on the role of $5-\mathrm{HT}_{3} \mathrm{R}$ in depression, see Rajkumar and Mahesh (2010), Bétry et al. (2011), and Gupta et al. (2016).

\section{B. Anxiety}

Anxiety disorders were classified according to the fourth edition of the Diagnostic and Statistical Manual of Mental Disorders as panic disorder, generalized anxiety disorder, social anxiety disorder, post-traumatic stress disorder (PTSD), specific phobia, and obsessivecompulsive disorder (OCD) (Ravindran and Stein, 2010). In the fifth edition of the Diagnostic and Statistical Manual of Mental Disorders, OCD has been placed in a new category, obsessive-compulsive and related disorders (Van Ameringen et al., 2014). Antidepressant drugs are prescribed for both depression and anxiety disorders, suggesting some overlap between the underpinning neuropathologies.

The animal tasks commonly used to test the anxiolytic properties of compounds comprise rodent conflict models of anxiety such as the dark-light emergence test, exploration tests including the elevated plus maze and open field tests, and social tasks such as social competition and social interaction tests (Rodgers, 1997).

A role for $5-\mathrm{HT}_{3} \mathrm{R}$ in anxiety-related behaviors has been the subject of several studies, and antagonists, including tropisetron, granisetron, ondansetron, and zacopride, have repeatedly demonstrated an array of antianxiety effects in various experimental models of anxiety. Nevertheless, they display differential efficacy across and within experiments and there are reports indicating that they have no effect (Jones et al., 1988; Costall and Naylor, 1992; Filip et al., 1992).
In an attempt to identify the neuroanatomical sites of anxiolytic-like action of $5-\mathrm{HT}_{3} \mathrm{R}$ antagonists, Costall et al. (1989) injected male mice with tropisetron and ondansetron in various brain regions. Although microinjection in the medial raphe nucleus, striatum, and NAc was without effect, $5-\mathrm{HT}_{3} \mathrm{R}$ blockade in the amygdala and $\mathrm{DRN}$ gave rise to a behavioral profile in the dark/light box test that was very similar to that caused by diazepam (Costall et al., 1989), thus uncovering the cerebral topography for the antianxiety effects of this class.

Further evidence for the involvement of $5-\mathrm{HT}_{3} \mathrm{R}$ in anxiety-related behaviors lies in the findings of a study on anabolic androgenic steroid (AAS)-treated hamsters. Concomitant provocation of aggression and reduction of anxious behaviors during exposure to AAS in adolescence was accompanied by a downregulation of $5-\mathrm{HT}_{3} \mathrm{R}$ across the regions associated with both aggression and anxiety, including the anterior hypothalamus, medial amygdala, central amygdaloid nucleus, and bed nucleus of the stria terminalis (Morrison et al., 2015). The relevance of such molecular alteration to the anxiolytic outcome of AAS treatment, as assessed in the elevated plus maze test, was proven by the loss of the effect upon $5-\mathrm{HT}_{3} \mathrm{R}$ agonist treatment.

In emotional processing tasks with demonstrated sensitivity to SSRI administration, antagonism at $5-\mathrm{HT}_{3}$ was shown to abolish the emotion-potentiated startle effect in healthy subjects. This observation corroborates the anxiolytic actions of $5-\mathrm{HT}_{3} \mathrm{R}$ antagonism in animal models and suggests the engagement of $5-\mathrm{HT}_{3} \mathrm{R}$ in certain physiologic aspects of fear processing and in the effects of serotonergic manipulations on anxiety in humans (Harmer et al., 2006).

Accordingly, in genetic studies, targeted gene deletion of the $5-\mathrm{HT}_{3 \mathrm{~A}}$ receptor in mice led to decreased indices of anxiety in the elevated plus maze, novel object interaction, and dark-light emergence tests (Kelley et al., 2003a), whereas in another study the same genotype was associated with the anxiolytic-like phenotype in the elevated plus maze test but not the dark-light box test (Bhatnagar et al., 2004). 5- $\mathrm{HT}_{3 \mathrm{~A}}$ null mice also exhibited dampened adrenocorticotropic hormone responses to distinct acute stressors, including LPS and restraint, indicating that $5-\mathrm{HT}_{3 \mathrm{~A}}$ deletion affects stress-induced but not basal HPA activity. However, CRH levels were unaltered after the same acute challenges and pituitary corticotroph sensitivity to the stimulatory effects of exogenous $\mathrm{CRH}$ remained similar in wild-type and knockout mice (Bhatnagar et al., 2004). Intracerebroventricular administration of bemesetron, a $5-\mathrm{HT}_{3 \mathrm{~A}}$ receptor antagonist (Table 1), also blunted the corticosterone response to acoustic stress (Saphier et al., 1995), suggesting that the $5-\mathrm{HT}_{3 \mathrm{~A}}$ receptor normally has a general stimulatory effect on acute stress-induced HPA activity.

1. Human Genetic Findings. Functional magnetic resonance imaging studies demonstrate that a single 
nucleotide polymorphism (SNP) identified in the regulatory region of HTR3A is correlated with higher activity in the amygdala and PFC as well as greater anxiety symptoms during emotional and nonemotional tasks in humans (Iidaka et al., 2005; Kilpatrick et al., 2011). The same polymorphism was found to modulate receptor expression through altering its translation rate in vitro (Niesler et al., 2001), lending more support to a link between $5-\mathrm{HT}_{3} \mathrm{R}$ and anxiety.

2. Obsessive-Compulsive Disorder. OCD, as its name suggests, is characterized by recurrent, intrusive, and distressing thoughts, images, or impulses (obsessions) and repetitive, seemingly purposeful behaviors that a person feels compelled to perform (compulsions) (Soltani et al., 2010).

The most studied animal behavioral batteries of OCD comprise 8-hydroxy-2-(di- $n$-propylamino)tetralin hydrobromide-induced decreased alternation, quinpirole-induced compulsive checking, marble burying, signal attenuation, and spontaneous stereotypy in deer mice (Albelda and Joel, 2012). It should be kept in mind, however, that animal models reflect only a fraction of human behavior due to the complexity of OCD symptoms.

Based on neuroimaging studies in human subjects with OCD, the regions most consistently associated with pathophysiology of symptoms are the cingulate cortex, orbitofrontal cortex, basal ganglia, and parietal lobe. Dysfunction of multiple neurotransmission circuitries has been implicated in the pathophysiology of the disorder, including serotonergic, dopaminergic, and glutamatergic systems. Dysregulation of the serotonergic system has been primarily suggested due to the effectiveness of SSRIs in alleviating obsessions and compulsions in patients (Zohar and Insel, 1987; Zohar et al., 1992) and has received further support from neurobiological, pharmacological, and more recently genetic data (Albelda and Joel, 2012).

a. Clinical Findings. In double-blind placebo-control pilot clinical trials, ondansetron treatment as an adjunct to fluoxetine as well as a low-dose granisetron add-on to fluvoxamine, both prescribed for 8 weeks to nonmedicated subjects with OCD, improved obsessive and compulsive symptoms (Soltani et al., 2010; Askari et al., 2012). The ondansetron add-on, given at low doses for 12 weeks, was also effective in reducing Yale-Brown Obsessive-Compulsive Scale scores in patients who were unresponsive to conventional OCD medications (Pallanti et al., 2009).

In light of these findings, the new generation of multimodal agents such as vortioxetine, which also antagonizes $5-\mathrm{HT}_{3} \mathrm{R}$, might prove more efficacious in controlling OCD symptoms than their predecessors.

b. Human Genetic Findings. Genetic findings in patients with OCD substantiate the clinical benefit of setrons in this disorder. HTR3D variant rs1000592 demonstrated a significant association with OCD, whereas
HTR3C variant rs6766410 was linked with OCD only in male individuals. Among patients with OCD, HTR3E variant rs7627615 coded for higher scores in the washing subtype and worse visual organization (Lennertz et al., 2014).

3. Post-Traumatic Stress Disorder, a Different Case. An accepted animal model for PTSD is Pavlovian fear conditioning, which sufficiently mimics the traumatic events that induce symptoms of an intense and recurrent fear characteristic of patients with PTSD (Zovkic and Sweatt, 2013). Setrons have not yet been tested in PTSD models. However, a key study showed that $5-\mathrm{HT}_{3 \mathrm{~A}}$ knockout mice exhibited a significant enhancement of conditional freezing and a blunted fear response extinction in the fear conditioning task in contrast to their anxiolytic behavior in the elevated plus maze test (Bhatnagar et al., 2004). Using a different fear conditioning protocol, another group reported no change in acquisition of fear memory but a significantly impaired extinction of learned fear in $5-\mathrm{HT}_{3 \mathrm{~A}}$ knockout mice (Kondo et al., 2013).

The aggravated fearful behavior of knockouts in classic conditioning could emanate from $5-\mathrm{HT}_{3 \mathrm{~A}}$ deficitprovoked perturbations in neural circuits of brain structures engaged in fear conditioning. These major players are the amygdala, which governs acquisition and extinction of fear memory; the $\mathrm{PFC}$, which regulates the amygdala; and the hippocampus, which encodes the context in which the CS-US association is learned, expressed, and extinguished (LeDoux, 2015). As mentioned earlier, $5-\mathrm{HT}_{3} \mathrm{Rs}$ are abundantly found on GABAergic interneurons in all of these regions. One possibility is that $5-\mathrm{HT}_{3 \mathrm{~A}}$ receptor ablation reinforces fear memory by influencing the formation of CS-US association in the amygdala. which receives major serotonergic inputs from the DRN (Ma et al., 1991). In mechanically dissociated BLA neurons with intact presynaptic nerve terminals, stimulation of presynaptic $5-\mathrm{HT}_{3} \mathrm{R}$ facilitates GABA release from interneurons, whereas this effect is blocked by $5-\mathrm{HT}_{3} \mathrm{R}$ antagonism (Koyama et al., 1999). Therefore, it is plausible that disruption of serotonergic-mediated GABAergic release leads to disinhibition of glutamatergic principal neurons of BLA, which in turn, project to and excite central amygdala to drive a heightened fear response.

The enhancement of fear conditioning in the absence of functional $5-\mathrm{HT}_{3 \mathrm{~A}}$ receptors suggests that despite their documented anxiolytic properties, $5-\mathrm{HT}_{3} \mathrm{R}$ antagonists might precipitate symptoms in patients with PTSD.

4. Advantageous Adverse Effect Profile of 5-HT Receptor Antagonists. $5-\mathrm{HT}_{3} \mathrm{R}$ antagonists are advantageous over anxiolytic benzodiazepines routinely used in anxiety disorders, in that they do not possess sedative/ hypnotic properties and are not associated with dependence or withdrawal issues after discontinuation of longterm use (Faerber et al., 2007) (Fig. 3). A lack of sedative 
and motor-incapacitating effects has also been observed in animal models (Costall and Naylor, 1992) although anxiolytic behavioral profile of 5-HT3R antagonists replicates that of benzodiazepines. This is of particular clinical significance and emerges from the fact that, in stark contrast to classic anxiolytics, $5-\mathrm{HT}_{3} \mathrm{R}$ antagonists are devoid of either direct agonistic action on GABA receptors or a potentiating effect on GABAergic neurotransmission (Carboni et al., 1989b). In fact, as mentioned earlier, antagonism of $5-\mathrm{HT}_{3} \mathrm{R}$ appears to curtail the synaptic release of GABA (Turner et al., 2004) (Fig. 2).

\section{Schizophrenia}

Schizophrenia has been primarily associated with DA dysfunction, and treatments have been developed that target the DA pathway in the CNS (Grace, 2016; Yang and Tsai, 2017). However, existing medications control the positive symptoms in only half of patients, while leaving negative symptoms and cognitive impairment mostly untreated (Stępnicki et al., 2018). There remains an enormous need for a better appreciation of schizophrenia pathophysiology and development of novel treatment approaches. Emerging evidence from genome-wide association studies goes beyond the DA type 2 receptor (as the target of antipsychotics) and extends the schizophrenia association to proteins in glutamatergic neurotransmission and synaptic plasticity (Ripke et al., 2014).

Efficacy of $5-\mathrm{HT}_{3} \mathrm{R}$ antagonists has been tested in experimental settings. Similar to typical (haloperidol) and atypical (sertindole) antipsychotics (Valenti et al., 2011), chronic administration of granisetron and its analog BRL 46470A reduces the number of spontaneously active DA neurons in the VTA. The effect appears to follow a multiphasic dose-response pattern and, unlike antipsychotics, is not mediated by depolarization block (Ashby et al., 1994).

Abnormality in auditory-evoked P50 potential is regarded as a neurophysiological endophenotype (Hazlett et al., 2015) of schizophrenia and may constitute a sensitive biomarker for patient response to medication. In DBA/2 mice, a single dose of tropisetron attenuated the spontaneously developed deficit in the hippocampus P20N40, a rodent analog of P50 sensory gating. The effect was offset upon coadministration of an $\alpha 7 \mathrm{nAChR}$ antagonist (Hashimoto et al., 2005) and was recapitulated by using a pure agonist at this receptor subtype (Simosky et al., 2001), raising the possibility that tropisetron agonistic activity on $\alpha 7 \mathrm{nAChR}$ is the underpinning mechanism. However, the same $\alpha 7 \mathrm{nAChR}$-dependent effects were observed with ondansetron, a setron with no affinity for $\alpha 7 \mathrm{nAChR}$ (Wildeboer et al., 2009). Similar to the animal findings, ondansetron attenuated P50 sensory gating in medicated patients (Adler et al., 2005). Inhibition of $5-\mathrm{HT}_{3} \mathrm{R}$ releases $\mathrm{ACh}$, the endogenous ligand for nAChRs. Indirect stimulation of nAChRs by ondansetron therefore can improve auditory gating parameters in $\mathrm{DBA} / 2$ mice.

Cognitive deficits are an integral part of schizophreniarelated symptoms, which manifest as disruption of

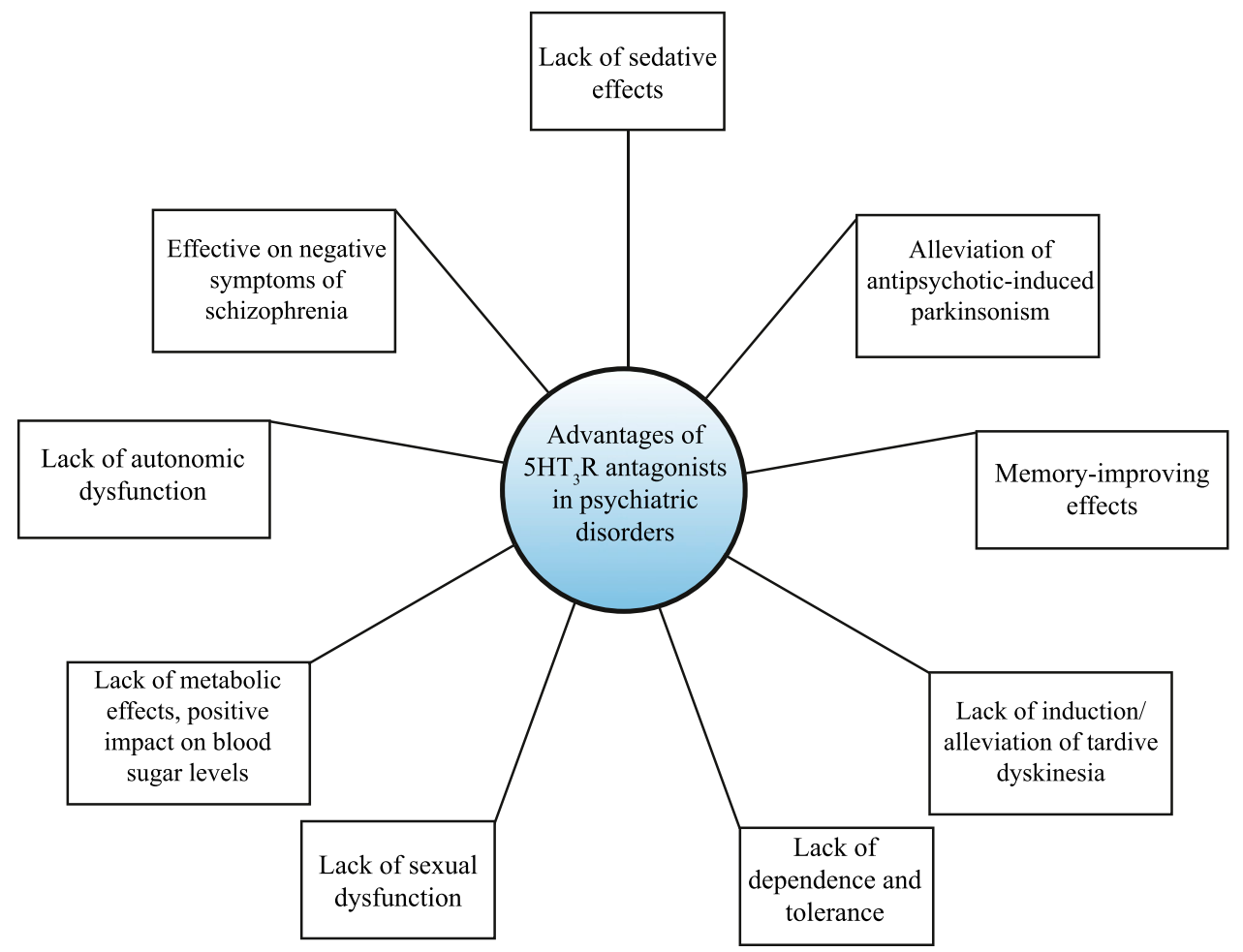

Fig. 3. Advantageous therapeutic prolife of $5 \mathrm{HT}_{3} \mathrm{R}$ antagonists over conventional medications prescribed for psychiatric disorders. 
memory (working, visual, and verbal), executive functioning, sustained attention, and processing speed. These manifestations often precede other symptoms and respond inadequately to antipsychotic therapy (Harvey et al., 2004). Ondansetron reverses amphetamine-derived impaired latent inhibition when given at a low dose to rats and improves learning and memory (Akhondzadeh et al., 2009).

1. Pharmacological Action of Antipsychotics on $5-H T_{3}$ Receptors. Similar to the effects of antidepressants, unrelated classes of antipsychotics, including phenothiazines, thioxanthenes, and butyrophenones, colocalize with $5-\mathrm{HT}_{3} \mathrm{Rs}$ in plasma membrane raft-like domains (Eisensamer et al., 2005) and demonstrate a potent antagonism against 5-HT-evoked sodium and calcium currents (Hermann et al., 1996; Rammes et al., 2004), suggesting a role for $5-\mathrm{HT}_{3} \mathrm{Rs}$ in their antischizophrenic efficacy. This observation was made with both the endogenous murine neuronal $5-\mathrm{HT}_{3} \mathrm{R}$ and the recombinant human $5-\mathrm{HT}_{3 \mathrm{~A}}$ receptor stably expressed in human embryonic kidney 293 cells, with different profiles on peak and plateau (Rammes et al., 2004). With the exception of clozapine, which is a known competitive antagonist at the $5-\mathrm{HT}_{3 \mathrm{~A}}$ receptor (Watling et al., 1990; Wang et al., 1994), all antipsychotics tested displayed an insurmountable antagonistic trait, as evidenced by their inability to displace a selective competitive $5-\mathrm{HT}_{3} \mathrm{R}$ radioligand from the membrane fractions and supported by electrophysiological data. The effect was voltage independent and more pronounced after preincubation with any given antipsychotic, suggesting that the antagonism is not exerted through an open-state blockade (Rammes et al., 2004).

Because of the structural similarity that exists between $5-\mathrm{HT}_{3} \mathrm{R}$ and $\alpha 7 \mathrm{nAChR}$, one might think of ligands with therapeutically relevant affinities for both receptors. Indeed, tropisetron constitutes one such compound, acting as a partial agonist on the nicotinic receptor subtype. This dual action can be of particular benefit in the case of schizophrenia; $\alpha 7 \mathrm{nAChR}$ has been linked to the sensory gating deficits frequently reported in schizophrenia (Adler et al., 1998).

2. Antipsychotic-Induced Parkinsonism. A multitude of experimental studies have demonstrated the ameliorating effect of $5-\mathrm{HT}_{3} \mathrm{R}$ antagonists on antipsychotic-induced extrapyramidal symptoms (Silva et al., 1995; Zhang et al., 2006; Akhondzadeh et al., 2009; Ohno et al., 2011; Tatara et al., 2012). The underpinning mechanisms remain elusive but advances have been made over the last decade. Both systemic injection and local administration of ondansetron into the striatum inhibit bradykinesia induction (Ohno et al., 2011, 2015), implying that postsynaptic $5-\mathrm{HT}_{3} \mathrm{Rs}$ are somehow implicated in the induction or facilitation of antipsychoticevoked extrapyramidal symptoms. As $5-\mathrm{HT}_{3} \mathrm{R}$ agonists stimulate glutamate release in different brain areas (Ashworth-Preece et al., 1995; Funahashi et al., 2004;
Jeggo et al., 2005), it is plausible that $5-\mathrm{HT}_{3} \mathrm{R}$ antagonists exert their beneficial effect by limiting glutamate release in the striatum (Ohno et al., 2015).

Finally, $5-\mathrm{HT}_{3} \mathrm{R}$ antagonist adjunct therapy may be of additional benefit to antipsychotic-associated tardive dyskinesia, an irreversible motor side effect of long-term antipsychotic treatment. Both tropisetron and ondansetron dose-dependently reverse haloperidol-induced vacuous chewing movements, a rodent analog of tardive dyskinesia; therefore, a $5-\mathrm{HT}_{3} \mathrm{R}$ antagonist class effect is conceivable (Naidu and Kulkarni, 2001).

3. Clinical Findings. $5-\mathrm{HT}_{3} \mathrm{R}$ antagonists as an add-on therapy have shown promising effects against the most intractable symptoms of schizophrenia, namely negative and cognitive symptoms. In treatment-resistant patients with chronic schizophrenia, the addition of ondansetron for 12 weeks significantly improved negative symptoms, general psychopathology, and cognition and significantly lowered the incidence and severity of haloperidol-induced parkinsonism and akathisia (Silva et al., 1995; Zhang et al., 2006; Akhondzadeh et al., 2009; Ohno et al., 2011; Tatara et al., 2012). Ondansetron was associated with attenuation of negative symptoms as well as visual memory correlates, including visual reproduction, visual paired associate learning, and figural memory, when administered as an adjunct to risperidonemedicated patients (Akhondzadeh et al., 2009). Similarly, in a double-blind, placebo-controlled 8-week trial, the addition of tropisetron to risperidone improved the primary negative symptoms of patients with chronic stable schizophrenia with no additional adverse effects (Noroozian et al., 2013). Add-on therapy with tropisetron as short as 10 days could also improve cognitive impairments in patients stabilized on risperidone (Zhang et al., 2012).

In addition to schizophrenia symptoms, this class of drugs also shows promise for the alleviation of nonmotor symptoms for patients with $\mathrm{PD}$, including medication-induced psychosis and behavioral side effects (Zoldan et al., 1996; Ohno et al., 2015). Indeed, in an open-label study conducted over 4-8 weeks, daily doses of ondansetron given to patients with L-dopaassociated psychosis of 6- to 60-month duration ameliorated paranoid delusions, visual hallucinations, confusion, and related global functional impairment. Interestingly, this add-on therapy was well tolerated and did not affect the efficacy of L-dopa in controlling the main symptoms of PD (Zoldan et al., 1995).

4. Human Genetic Findings. Genetic studies implicate the $5-\mathrm{HT}_{3 \mathrm{E}}$ subunit in cognition-related endophenotypes in schizophrenia. Sustained attention was evaluated using the continuous performance test in healthy controls as well as in patients who were stable while taking medication. Of six common functional and coding variants of the subunit genes, $5-\mathrm{HT}_{3}$ variant rs7627615 was associated with better attentional capacities in individuals from both cohorts 
(Lennertz et al., 2010). In pharmacogenetic studies, the same HT3RE SNP codes for a faster response to antipsychotic treatment. Patients harboring this variant displayed a quicker improvement in negative symptoms when treated with risperidone or haloperidol (Schuhmacher et al., 2009). In a case-control study conducted in a South Indian population, a significant association was observed for HT3RA functional variant rs1062613 (Jajodia et al., 2015).

5. Advantageous Adverse Effect Profile. In terms of adverse effects, $5-\mathrm{HT}_{3} \mathrm{R}$ antagonists are advantageous over both antipsychotic classes. Unlike the first generation antypsychotic, owing to the lack of interaction with $\mathrm{DA} \mathrm{D}_{2} \mathrm{R}$, setrons do not promote and, as stated above, may even act to counteract tardive dyskinesia (Naidu and Kulkarni, 2001). Moreover, unlike atypical antipsychotics that cause insulin intolerance and obesity (MacKenzie et al., 2018), setrons lack metabolic effects and rather exert a positive effect on glucose metabolism (Fig. 3). As detailed in section IV.F, blockade of the central $5-\mathrm{HT}_{3} \mathrm{R}$ results in a decrease of blood glucose levels, whereas antagonism at these receptors in the periphery leads to curtailed insulin secretion from pancreatic $\beta$-cells (Rahimian et al., 2013a). Indeed, based on animal studies, $5-\mathrm{HT}_{3} \mathrm{R}$ has been proposed as a novel target to prevent obesity (Weber et al., 2009).

\section{Drugs of Abuse}

A common denominator of substances of abuse is their action to boost the mesolimbic DA pathway as an integral part of the reward system, thereby driving reinforcing and seeking effects (Pierce and Kumaresan, 2006). This pathway consists of dopaminergic neurons located in the VTA in the brain stem, sending their projections to limbic structures including the NAc and amygdala (Volkow and Morales, 2015). Such influence is exerted either through a direct action on components of the dopaminergic system as do psychostimulants (e.g., amphetamines and cocaine) or rather through nondopaminergic receptors that are part of the regulatory systems of this pathway, among which are 5-HT, GABA, and opioidergic systems (Engleman et al., 2008). Opiates stimulate the endogenous opioid receptors on GABAergic interneurons that inhibit mesolimbic DA neurons. Their resultant disinhibition leads to an enhancement of DA transmission within the mesolimbic system (Alex and Pehek, 2007).

1. Modulation of Neurotransmission. Because of the diversity of 5-HT receptor subtypes that transduce various signals and their distribution, 5 -HT can give rise to a complex outcome. In the case of $5-\mathrm{HT}_{3} \mathrm{Rs}$, although they are expressed at very low densities across areas such as the NAc, VTA, striatum, substantia nigra, and DRN (Gehlert et al., 1991; Engleman et al., 2008), there are substantial electrophysiological and macrodialysis data indicating that $5-\mathrm{HT}_{3} \mathrm{Rs}$ influence DA activity in these regions. $5-\mathrm{HT}_{3} \mathrm{Rs}$ modulate phasic DA release within the NAc, where they appear to be expressed preferentially on presynaptic dopaminergic terminals projecting from the VTA (Blandina et al., 1988; Mylecharane, 1996). Activation of $5-\mathrm{HT}_{3}$ ion channels on these axons enhances calcium influx leading to liberation of DA into the NAc, thereby reinforcing reward. Antagonists, on the other hand, partially prevent drug-induced stimulation of mesolimbic DA release and decrease craving.

Early pieces of evidence for $5-\mathrm{HT}_{3} \mathrm{R}$ antagonist indication in addiction go back to the late 1980s. These agents were shown to block morphine- and nicotineevoked place preference conditioning (Carboni et al., 1989b), suggesting their effect in preventing the rewarding properties of both substances. In the same vein, $5-\mathrm{HT}_{3} \mathrm{R}$ blockade counteracts morphine- and nicotine-induced DA release in the NAc (Carboni et al., 1989a; Imperato and Angelucci, 1989; Pei et al., 1993). Antagonism at $5-\mathrm{HT}_{3} \mathrm{R}$ reduces ethanol consumption and disrupts response to ethanol in an ethanol discrimination task (Higgins et al., 1992) as a consequence of attenuating the ethanol-derived DA release in the NAc (Carboni et al., 1989a; Wozniak et al., 1990). Similar neurochemical effects as well as attenuation of place preference acquisition were observed with MDL 72222, a potent and selective $5-\mathrm{HT}_{3}$ antagonist, when using cocaine and stimulant amines amphetamine and mazindol as reinforcing drugs (Kankaanpää et al., 1996, 2002). Various $5-\mathrm{HT}_{3} \mathrm{R}$ antagonists inhibit benzodiazepine binding to both native and recombinant $\mathrm{GABA}_{\mathrm{A}}$ receptors and curtail the evoked chloride currents (Klein et al., 1994). However, MDL 72222 failed to influence measures of ketamineprovoked psychotomimetic effects in rodents (Kos et al., 2006). Figure 2 depicts the effects of $5-\mathrm{HT}_{3} \mathrm{R}$ antagonists on neurotransmitter systems.

2. Clinical Findings. $5-\mathrm{HT}_{3} \mathrm{R}$ antagonists have been used successfully in the treatment of alcoholism, especially early-onset alcoholism. In a double-blind, randomized placebo-controlled clinical trial, ondansetron was effective in reducing alcohol consumption in individuals with early-onset but not late-onset alcoholism (Johnson et al., 2000b). The same effect was repeated in a smaller male population over a shorter course of treatment (Kranzler et al., 2003). Ondansetron also reduced alcohol craving in these subjects (Johnson et al., 2002). Furthermore, ondansetron displayed additional effects on decreasing alcohol drinking (Johnson et al., 2000a) and craving (Ait-Daoud et al., 2001) in this population target when combined with naltrexone.

In addition, twice-daily tropisetronin administered in a clinical trial conducted with cocaine users was beneficial in increasing cocaine-free days in the week (Colombo et al., 2006).

Nevertheless, despite promising preclinical findings on other drugs of abuse, $5-\mathrm{HT}_{3} \mathrm{R}$ antagonists have failed clinically. When conducted with subjects with 
benzodiazepine (Romach et al., 1998), nicotine (Hatsukami et al., 2003), amphetamine (Johnson et al., 2008), or opiate (Sell et al., 1995) use disorder, clinical trials reveal no effect by setrons on any aspect, including dosage, craving, or withdrawal symptoms, at least not with the therapeutic regimens practiced.

\section{E. Other Neuropsychiatric Disorders}

Although pharmacological assessment of a role for $5-\mathrm{HT}_{3} \mathrm{Rs}$ is lacking in other neuropsychiatric disorders, genetic studies have begun to unravel the significance of these receptors. In HTR3A and HTR3B, three functional SNPs (rs1062613, rs1176744, and rs3831455) have consistently been associated with bipolar disorder among different ethnic groups (Hammer et al., 2012). Epigenetic modification of HTR3A has also been implicated in the clinical severity of three psychiatric disorders. The DNA methylation status of the gene was associated with the severity of bipolar disorder, borderline personality disorder, and adult attention-deficit/ hyperactivity disorder (Perroud et al., 2016).

\section{Concluding Remarks}

Ligand-gated ion channels are the second most important targets for drug discovery only after G proteincoupled receptors. Various ligand-gated ion channel receptors, such as $\mathrm{GABA}_{\mathrm{A}}$, nicotinic, $N$-methyl-D-aspartate, $\mathrm{P} 2 \mathrm{X}$, and $5-\mathrm{HT}_{3}$, have been characterized thus far. The neuropharmacology of $5-\mathrm{HT}_{3} \mathrm{Rs}$ has been overshadowed by other members of this large family. One main reason is that the identification of $5-\mathrm{HT}_{3} \mathrm{Rs}$ did not occur until mid-1980s, owing to a lack of selective pharmacological tools. In the $1990 \mathrm{~s}, 5-\mathrm{HT}_{3} \mathrm{R}$ antagonists revolutionized the treatment of chemotherapy-induced emesis. Nonetheless, other therapeutic potentials of this class were neglected for years until recent investigations demonstrated that these compounds could alleviate the pathology of certain neurodegenerative and neuropsychiatric disorders. As detailed in the previous sections, $5-\mathrm{HT}_{3} \mathrm{R}$ antagonists modulate neurotransmitters and their neural networks in brain regions associated with these conditions (Fig. 2). Setrons, via various mechanisms, can also counteract neuroinflammation, a phenomenon increasingly regarded as a centerpiece in the pathogenesis of neurologic and psychiatric disorders, as part of their protective properties. Interestingly and despite their anti-inflammatory actions, immunosuppression has not yet been reported with setrons.

However, a tantalizing potential of setrons is in the management of schizophrenia and alcohol use disorder. In clinical trials, setrons have shown promising effects against the most intractable symptoms of schizophrenia, namely negative and cognitive symptoms. Setrons have also been very successful in treating earlyonset alcohol dependence. The condition is presumably associated with major serotonergic dysfunction, including overexpression of postsynaptic $5-\mathrm{HT}_{3} \mathrm{R}$ in the mesolimbic DA system (Johnson and Ait-Daoud, 2000). This is a particularly big advancement in the treatment of alcoholism, since this type presents as the most refractory to treatment and highly comorbid with psychosocial problems such as antisocial behaviors (Johnson and Ait-Daoud, 2000).

The lack of many adverse effects linked with conventional treatments available for psychiatric disorders such as abuse liability, sedation, glucose intolerance, and propensity to induce tardive dyskinesia (Fig. 3) is clinically relevant and can benefit patients suffering from psychiatric diseases. Given the advantageous therapeutic profile of $5-\mathrm{HT}_{3} \mathrm{R}$ antagonists combined with their broad therapeutic window, more detailed studies on this class of drugs could open avenues for the development of novel pharmacophores with higher efficacy and better compliance for the management of neurologic and neuropsychiatric disorders.

\section{Authorship Contributions}

Wrote or contributed to the writing of the manuscript: Fakhfouri, Rahimian, Dyhrfjeld-Johnsen, Zirak, Beaulieu.

\section{References}

Adler LE, Cawthra EM, Donovan KA, Harris JG, Nagamoto HT, Olincy A, and Waldo MC (2005) Improved p50 auditory gating with ondansetron in medicated schizophrenia patients. Am J Psychiatry 162:386-388.

Adler LE, Olincy A, Waldo M, Harris JG, Griffith J, Stevens K, Flach K, Nagamoto H, Bickford P, Leonard S, et al. (1998) Schizophrenia, sensory gating, and nicotinic receptors. Schizophr Bull 24:189-202.

Ait-Daoud N, Johnson BA, Prihoda TJ, and Hargita ID (2001) Combining ondansetron and naltrexone reduces craving among biologically predisposed alcoholics: preliminary clinical evidence. Psychopharmacology (Berl) 154:23-27.

Akhondzadeh S, Mohammadi N, Noroozian M, Karamghadiri N, Ghoreishi A, Jamshidi A-H, and Forghani S (2009) Added ondansetron for stable schizophrenia: a double blind, placebo controlled trial. Schizophr Res 107:206-212.

Albelda N and Joel D (2012) Animal models of obsessive-compulsive disorder: exploring pharmacology and neural substrates. Neurosci Biobehav Rev 36:47-63.

Alex KD and Pehek EA (2007) Pharmacologic mechanisms of serotonergic regulation of dopamine neurotransmission. Pharmacol Ther 113:296-320.

Alfirevic A, Mills T, Carr D, Barratt BJ, Jawaid A, Sherwood J, Smith JC, Tugwood J, Hartkoorn R, Owen A, et al. (2007) Tacrine-induced liver damage: an analysis of 19 candidate genes. Pharmacogenet Genomics 17:1091-1100.

Alhaj MW, Zaitone SA, and Moustafa YM (2015) Fluvoxamine alleviates seizure activity and downregulates hippocampal GAP-43 expression in pentylenetetrazolekindled mice: role of 5- $\mathrm{HT}_{3}$ receptors. Behav Pharmacol 26:369-382.

Aminian A, Noorbakhsh F, Ghazi-Khansari M, Kafami L, Javadi S, Hassanzadeh G, Rahimian R, Dehpour AR, and Mehr SE (2013) Tropisetron diminishes demyelination and disease severity in an animal model of multiple sclerosis. $\mathrm{Neu}$ roscience 248:299-306.

Amiri Gheshlaghi S, Mohammad Jafari R, Algazo M, Rahimi N, Alshaib H, and Dehpour AR (2017) Genistein modulation of seizure: involvement of estrogen and serotonin receptors. J Nat Med 71:537-544.

Arnsten AF, Lin CH, Van Dyck CH, and Stanhope KJ (1997) The effects of 5-HT receptor antagonists on cognitive performance in aged monkeys. Neurobiol Aging 18:21-28.

Ashby CR Jr, Minabe Y, Edwards E, and Wang RY (1991) 5- $\mathrm{HT}_{3}$-like receptors in the rat medial prefrontal cortex: an electrophysiological study. Brain Res 550:181-191.

Ashby CR, Minabe Y, Toor A, Fishkin LD, Granoff MI, and Wang RY (1994) Effect produced by acute and chronic administration of the selective $5-\mathrm{HT}_{3}$ receptor antagonist BRL 46470 on the number of spontaneously active midbrain dopamine cells in the rat. Drug Dev Res 31:228-236.

Ashworth-Preece MA, Jarrott B, and Lawrence AJ (1995) 5-Hydroxytryptamine3 receptor modulation of excitatory amino acid release in the rat nucleus tractus solitarius. Neurosci Lett 191:75-78.

Askari N, Moin M, Sanati M, Tajdini M, Hosseini S-M-R, Modabbernia A, Najand B, Salimi S, Tabrizi M, Ashrafi M, et al. (2012) Granisetron adjunct to fluvoxamine for moderate to severe obsessive-compulsive disorder: a randomized, double-blind, placebo-controlled trial. CNS Drugs 26:883-892.

Authier N, Gillet J-P, Fialip J, Eschalier A, and Coudore F (2003) A new animal model of vincristine-induced nociceptive peripheral neuropathy. Neurotoxicology 24:797-805.

Bachy A, Héaulme M, Giudice A, Michaud JC, Lefevre IA, Souilhac J, Manara L, Emerit MB, Gozlan H, Hamon M, et al. (1993) SR 57227A: a potent and selective agonist at central and peripheral $5-\mathrm{HT}_{3}$ receptors in vitro and in vivo. Eur $J$ Pharmacol 237:299-309. 
Baganz NL and Blakely RD (2013) A dialogue between the immune system and brain, spoken in the language of serotonin. ACS Chem Neurosci 4:48-63.

Bagdy G, Kecskemeti V, Riba P, and Jakus R (2007) Serotonin and epilepsy. $J$ Neurochem 100:857-873.

Bahremand A, Payandemehr B, Rahimian R, Ziai P, Pourmand N, Loloee S, Ebrahimi A, Ghasemi A, Fakhfouri G, Ghasemi M, et al. (2011) The role of $\left.5-\mathrm{HT}_{3}\right)$ receptors in the additive anticonvulsant effects of citalopram and morphine on pentylenetetrazole-induced clonic seizures in mice. Epilepsy Behav 21: 122-127.

Balakrishnan S, Bhargava VK, and Pandhi P (2000) Anticonvulsant profile of ondansetron in rats. Epilepsy Behav 1:22-26.

Baptista-Hon DT, Deeb TZ, Othman NA, Sharp D, and Hales TG (2012) The 5-HT $\mathrm{HB}_{3 \mathrm{~B}}$ subunit affects high-potency inhibition of $5-\mathrm{HT}_{3}$ receptors by morphine. $\mathrm{Br} J$ Pharmacol 165:693-704.

Barann M, Molderings G, Brüss M, Bönisch H, Urban BW, and Göthert M (2002) Direct inhibition by cannabinoids of human 5- $\mathrm{HT}_{3 \mathrm{~A}}$ receptors: probable involvement of an allosteric modulatory site. $\mathrm{Br}$ J Pharmacol 137:589-596.

Barnes JM, Costall B, Coughlan J, Domeney AM, Gerrard PA, Kelly ME, Naylor RJ, Onaivi ES, Tomkins DM, and Tyers MB (1990) The effects of ondansetron, a 5- $\mathrm{HT}_{3}$ receptor antagonist, on cognition in rodents and primates. Pharmacol Biochem Behav 35:955-962.

Barzegar-Fallah A, Alimoradi H, Mehrzadi S, Barzegar-Fallah N, Zendedel A, Abbasi A, and Dehpour AR (2014) The neuroprotective effect of tropisetron on vincristineinduced neurotoxicity. Neurotoxicology 41:1-8.

Berman SM, Chang L, Suyenobu B, Derbyshire SW, Stains J, Fitzgerald L, Mandelkern M, Hamm L, Vogt B, Naliboff BD, et al. (2002) Condition-specific deactivation of brain regions by $5-\mathrm{HT}_{3}$ receptor antagonist alosetron. Gastroenterology 123:969-977.

Bertrand D, Lee CH, Flood D, Marger F, and Donnelly-Roberts D (2015) Therapeutic potential of $\alpha 7$ nicotinic acetylcholine receptors. Pharmacol Rev 67:1025-1073.

Bétry C, Etiévant A, Oosterhof C, Ebert B, Sanchez C, and Haddjeri N (2011) Role of $5-\mathrm{HT}_{3}$ receptors in the antidepressant response. Pharmaceuticals (Basel) 4: $603-629$

Bétry C, Overstreet D, Haddjeri N, Pehrson AL, Bundgaard C, Sanchez C, and Mørk A (2015) A 5- $\mathrm{HT}_{3}$ receptor antagonist potentiates the behavioral, neurochemical and electrophysiological actions of an SSRI antidepressant. Pharmacol Biochem Behav 131:136-142.

Bhatnagar S, Sun LM, Raber J, Maren S, Julius D, and Dallman MF (2004) Changes in anxiety-related behaviors and hypothalamic-pituitary-adrenal activity in mice lacking the 5-HT-3A receptor. Physiol Behav 81:545-555.

Bisdorff A, Bosser G, Gueguen R, and Perrin P (2013) The epidemiology of vertigo, dizziness, and unsteadiness and its links to co-morbidities. Front Neurol 4:29.

Blandina P, Goldfarb J, and Green JP (1988) Activation of a 5- $\mathrm{HT}_{3}$ receptor releases dopamine from rat striatal slice. Eur J Pharmacol 155:349-350.

Boeijinga PH, Galvan M, Baron BM, Dudley MW, Siegel BW, and Slone AL (1992) Characterization of the novel 5- $\mathrm{HT}_{3}$ antagonists MDL 73147EF (dolasetron mesilate) and MDL 74156 in NG108-15 neuroblastoma x glioma cells. Eur J Pharmacol 219:9-13.

Boess FG, De Vry J, Erb C, Flessner T, Hendrix M, Luithle J, Methfessel C, Riedl B, Schnizler K, van der Staay FJ, et al. (2007) The novel alpha7 nicotinic acetylcholine receptor agonist N-[(3R)-1-azabicyclo[2.2.2]oct-3-yl]-7-[2-(methoxy)phenyl]-1benzofuran-2-carboxamide improves working and recognition memory in rodents. J Pharmacol Exp Ther 321:716-725.

Bonaz B (2013) Inflammatory bowel diseases: a dysfunction of brain-gut interactions? Minerva Gastroenterol Dietol 59:241-259.

Bonaz B, Baciu M, Papillon E, Bost R, Gueddah N, Le Bas JF, Fournet J, and Segebarth C (2002) Central processing of rectal pain in patients with irritable bowel syndrome: an fMRI study. Am J Gastroenterol 97:654-661.

Bordet R, Gelé P, Duriez P, and Fruchart J-C (2006a) PPARs: a new target for neuroprotection. J Neurol Neurosurg Psychiatry 77:285-287.

Bordet R, Ouk T, Petrault O, Gelé P, Gautier S, Laprais M, Deplanque D, Duriez P, Staels B, Fruchart JC, et al. (2006b) PPAR: a new pharmacological target for neuroprotection in stroke and neurodegenerative diseases. Biochem Soc Trans 34:1341-1346.

Brady CA, Dover TJ, Massoura AN, Princivalle AP, Hope AG, and Barnes NM (2007) Identification of $5-\mathrm{HT}_{3 \mathrm{~A}}$ and $5-\mathrm{HT}_{3 \mathrm{~B}}$ receptor subunits in human hippocampus. Neuropharmacology 52:1284-1290.

Brandt T, Zwergal A, and Strupp M (2009) Medical treatment of vestibular disorders. Expert Opin Pharmacother 10:1537-1548.

Buhot M-C, Martin S, and Segu L (2000) Role of serotonin in memory impairment. Ann Med 32:210-221.

Burghaus L, Schütz U, Krempel U, de Vos RA, Jansen Steur EN, Wevers A, Lindstrom J, and Schröder H (2000) Quantitative assessment of nicotinic acetylcholine receptor proteins in the cerebral cortex of Alzheimer patients. Brain Res Mol Brain Res 76:385-388.

Cai S, Huang S, and Hao W (2015) New hypothesis and treatment targets of depression: an integrated view of key findings. Neurosci Bull 31:61-74.

Cai Y-Q, Chen S-R, and Pan H-L (2013) Upregulation of nuclear factor of activated T-cells by nerve injury contributes to development of neuropathic pain. J Pharmacol Exp Ther 345:161-168.

Callahan PM, Bertrand D, Bertrand S, Plagenhoef MR, and Terry AV Jr (2017) Tropisetron sensitizes $\alpha 7$ containing nicotinic receptors to low levels of acetylcholine in vitro and improves memory-related task performance in young and aged animals. Neuropharmacology 117:422-433.

Campbell AD, Kohl RR, and McBride WJ (1996) Serotonin-3 receptor and ethanolstimulated somatodendritic dopamine release. Alcohol 13:569-574.

Candelario-Jalil E, Muñoz E, and Fiebich BL (2008) Detrimental effects of tropisetron on permanent ischemic stroke in the rat. BMC Neurosci 9:19.

Cappelli A, Gallelli A, Manini M, Anzini M, Mennuni L, Makovec F, Menziani MC, Alcaro S, Ortuso F, and Vomero S (2005) Further studies on the interaction of the 5-hydroxytryptamine3 $\left(5-\mathrm{HT}_{3}\right)$ receptor with arylpiperazine ligands. Development of a new $5-\mathrm{HT}_{3}$ receptor ligand showing potent acetylcholinesterase inhibitory properties. J Med Chem 48:3564-3575.
Carboni E, Acquas E, Frau R, and Di Chiara G (1989a) Differential inhibitory effects of a $5-\mathrm{HT}_{3}$ antagonist on drug-induced stimulation of dopamine release. Eur $J$ Pharmacol 164:515-519.

Carboni E, Acquas E, Leone P, and Di Chiara G (1989b) $5 \mathrm{HT}_{3}$ receptor antagonists block morphine- and nicotine- but not amphetamine-induced reward. Psychopharmacology (Berl) 97:175-178.

Carli M, Luschi R, and Samanin R (1997) Dose-related impairment of spatial learning by intrahippocampal scopolamine: antagonism by ondansetron, a $5-\mathrm{HT}_{3}$ receptor antagonist. Behav Brain Res 82:185-194.

Carrillo M, Ricci LA, Schwartzer JJ, and Melloni RH (2010) Immunohistochemical characterization of 5-HT(3A) receptors in the Syrian hamster forebrain. Brain Res 1329:67-81.

Carvalho F, Barros D, Silva J, Rezende E, Soares M, Fregoneze J, and de Castro-ESilva E (2005) Hyperglycemia induced by pharmacological activation of central erotonergic pathways depends on the functional integrity of brain $\mathrm{CRH}$ system and $5-\mathrm{HT}_{3}$ receptors. Horm Metab Res 37:482-488.

Carvalho F, Macêdo D, Bandeira I, Maldonado I, Salles L, Azevedo MF, Rocha MA Jr, Fregoneze JB, and De Castro-e-Silva E (2002) Central 5-HT $\mathrm{H}_{3}$ receptor stimulation by m-CPBG increases blood glucose in rats. Horm Metab Res 34:55-61.

Chau JK, Lin JR, Atashband S, Irvine RA, and Westerberg BD (2010) Systematic review of the evidence for the etiology of adult sudden sensorineural hearing loss. Laryngoscope 120:1011-1021.

Chen JP, van Praag HM, and Gardner EL (1991) Activation of 5-HT 3 receptor by 1-phenylbiguanide increases dopamine release in the rat nucleus accumbens. Brain Res 543:354-357.

Chugh Y, Saha N, Sankaranarayanan A, and Datta H (1991) Enhancement of memory retrieval and attenuation of scopolamine-induced amnesia following administration of 5- $\mathrm{HT}_{3}$ antagonist ICS 205-930. Pharmacol Toxicol 69:105-106.

Clark RD, Muchowski JM, Weinhardt KK, Dillon MP, Lee CH, Bley KR, Bonhaus DW, Wong EHF, and Eglen RM (1995) N-(Quinuclidin-3-yl)-2-(1-methyl-1H-indol3-yl)-2-oxo-acetamide: a high affinity $5-\mathrm{HT}_{3}$ receptor partial agonist. Bioorg Med Chem Lett 5:1853-1856.

Clouston PD, DeAngelis LM, and Posner JB (1992) The spectrum of neurological disease in patients with systemic cancer. Ann Neurol 31:268-273.

Colombo G, Lobina C, Carai MAM, and Gessa GL (2006) Phenotypic characterization of genetically selected sardinian alcohol-preferring $(\mathrm{sP})$ and -non-preferring (sNP) rats. Addict Biol 11:324-338.

Contrera KJ, Betz J, Deal J, Choi JS, Ayonayon HN, Harris T, Helzner E, Martin KR, Mehta K, Pratt S, et al.; Health ABC Study (2017) Association of hearing impairment and anxiety in older adults. J Aging Health 29:172-184.

Costall B, Kelly ME, Naylor RJ, Onaivi ES, and Tyers MB (1989) Neuroanatomical sites of action of $5-\mathrm{HT}_{3}$ receptor agonist and antagonists for alteration of aversive behaviour in the mouse. $\mathrm{Br} J$ Pharmacol 96:325-332.

Costall B and Naylor RJ (1992) Anxiolytic potential of 5-HT $\mathrm{H}_{3}$ receptor antagonists. Pharmacol Toxicol 70:157-162.

Crane RA, Camilon M, Nguyen S, and Meyer TA (2015) Steroids for treatment of sudden sensorineural hearing loss: a meta-analysis of randomized controlled trials. Laryngoscope 125:209-217.

Das P and Dillon GH (2005) Molecular determinants of picrotoxin inhibition of 5-hydroxytryptamine type 3 receptors. J Pharmacol Exp Ther 314:320-328.

Davies PA (2011) Allosteric modulation of the 5- $\mathrm{HT}_{3}$ ) receptor. Curr Opin Pharmacol 11:75-80.

Davies PA, Pistis M, Hanna MC, Peters JA, Lambert JJ, Hales TG, and Kirkness EF (1999) The $5-\mathrm{HT}_{3 \mathrm{~B}}$ subunit is a major determinant of serotonin-receptor function. Nature 397:359-363.

De Deurwaerdère P, Stinus L, and Spampinato U (1998) Opposite change of in vivo dopamine release in the rat nucleus accumbens and striatum that follows electrical stimulation of dorsal raphe nucleus: role of $5-\mathrm{HT}_{3}$ receptors. $J$ Neurosci 18: $6528-6538$

de la Vega L, Muñoz E, Calzado MA, Lieb K, Candelario-Jalil E, Gschaidmeir H, Färber L, Mueller W, Stratz T, and Fiebich BL (2005) The 5- $\mathrm{HT}_{3}$ receptor antagonist tropisetron inhibits $\mathrm{T}$ cell activation by targeting the calcineurin pathway. Biochem Pharmacol 70:369-380.

Deplanque D, Gelé P, Pétrault O, Six I, Furman C, Bouly M, Nion S, Dupuis B, Leys D, Fruchart J-C, et al. (2003) Peroxisome proliferator-activated receptor-alpha activation as a mechanism of preventive neuroprotection induced by chronic fenofibrate treatment. $J$ Neurosci 23:6264-6271.

Diez-Ariza M, García-Alloza M, Lasheras B, Del Río J, and Ramírez MJ (2002) GABA(A) receptor antagonists enhance cortical acetylcholine release induced by 5-HT(3) receptor blockade in freely moving rats. Brain Res $956: 81-85$.

Djaldetti R, Hart J, Alexandrova S, Cohen S, Beilin B-Z, Djaldetti M, and Bessler H (1996) Vincristine-induced alterations in Schwann cells of mouse peripheral nerve. Am J Hematol 52:254-257.

Downie DL, Hope AG, Belelli D, Lambert JJ, Peters JA, Bentley KR, Steward LJ, Chen CY, and Barnes NM (1995) The interaction of trichloroethanol with murine recombinant 5-HT $\mathrm{HT}_{3}$ receptors. Br J Pharmacol 114:1641-1651.

Downie DL, Hope AG, Lambert JJ, Peters JA, Blackburn TP, and Jones BJ (1994) Pharmacological characterization of the apparent splice variants of the murine 5-HT3 R-A subunit expressed in Xenopus laevis oocytes. Neuropharmacology 33:473-482.

Dubin AE, Huvar R, D’Andrea MR, Pyati J, Zhu JY, Joy KC, Wilson SJ, Galindo JE Glass CA, Luo L, et al. (1999) The pharmacological and functional characteristics of the serotonin $\left.5-\mathrm{HT}_{3 \mathrm{~A}}\right)$ receptor are specifically modified by a $5-\mathrm{HT}\left(_{3 \mathrm{~B}}\right)$ receptor subunit. J Biol Chem 274:30799-30810.

Dukat M, Abdel-Rahman AA, Ismaiel AM, Ingher S, Teitler M, Gyermek L, and Glennon RA (1996) Structure-activity relationships for the binding of arylpiperazines and arylbiguanides at $5-\mathrm{HT}_{3}$ serotonin receptors. $J$ Med Chem 39: $4017-4026$

Dyhrfjeld-Johnsen J (2016) inventor, Sensorion, assignee. Calcineurin inhibitors of the setron family for the treatment of hearing loss. French patent WO2016184900A1. 
Dyhrfjeld-Johnsen J (2017) inventor, Sensorion, assignee. (+)-Azasetron for use in the treatment of ear disorders. French patent WO2017178645A1.

Dyhrfjeld-Johnsen J, Gaboyard-Niay S, Broussy A, Saleur A, Brugeaud A and Chabbert C (2013) Ondansetron reduces lasting vestibular deficits in a model of severe peripheral excitotoxic injury. $J$ Vestib Res 23:177-186.

Eisensamer B, Rammes G, Gimpl G, Shapa M, Ferrari U, Hapfelmeier G, Bondy B, Parsons C, Gilling K, Zieglgänsberger W, et al. (2003) Antidepressants are functional antagonists at the serotonin type $3\left(5-\mathrm{HT}_{3}\right)$ receptor. Mol Psychiatry 8: 994-1007.

Eisensamer B, Uhr M, Meyr S, Gimpl G, Deiml T, Rammes G, Lambert JJ, Zieglgänsberger W, Holsboer F, and Rupprecht R (2005) Antidepressants and antipsychotic drugs colocalize with $5-\mathrm{HT}_{3}$ receptors in raft-like domains. J Neurosci 25:10198-10206.

Eissa Ahmed AA, Al-Rasheed NM, and Al-Rasheed NM (2009) Antidepressant-like effects of rosiglitazone, a PPAR $\gamma$ agonist, in the rat forced swim and mouse tail suspension tests. Behav Pharmacol 20:635-642.

Engleman EA, Rodd ZA, Bell RL, and Murphy JM (2008) The role of 5-HT 3 receptors in drug abuse and as a target for pharmacotherapy. CNS Neurol Disord Drug Targets 7:454-467.

Faerber L, Drechsler S, Ladenburger S, Gschaidmeier H, and Fischer W (2007) The neuronal $5-\mathrm{HT}_{3}$ receptor network after 20 years of research--evolving concepts in management of pain and inflammation. Eur J Pharmacol 560:1-8.

Fakhfouri G, Mousavizadeh K, Mehr SE, Dehpour AR, Zirak MR, Ghia J-E, and Rahimian R (2015) From chemotherapy-induced emesis to neuroprotection: therapeutic opportunities for 5-HT 3 receptor antagonists. Mol Neurobiol 52:1670-1679.

Fakhfouri G, Rahimian R, Ghia JE, Khan WI, and Dehpour AR (2012) Impact of $5-\mathrm{HT}_{3}$ receptor antagonists on peripheral and central diseases. Drug Discov Today 17:741-747.

Fan P (1994) Effects of antidepressants on the inward current mediated by $5-\mathrm{HT}_{3}$ receptors in rat nodose ganglion neurones. $\mathrm{Br}$ J Pharmacol 112:741-744.

Fichna J and Storr MA (2012) Brain-gut interactions in IBS. Front Pharmacol 3:127.

Fiebich BL, Akundi RS, Lieb K, Candelario-Jalil E, Gmeiner D, Haus U, Müller W, Stratz T, and Muñoz E (2004a) Antiinflammatory effects of 5- $\mathrm{HT}_{3}$ receptor antagonists in lipopolysaccharide-stimulated primary human monocytes. Scand $J$ Rheumatol Suppl 119:28-32.

Fiebich BL, Akundi RS, Seidel M, Geyer V, Haus U, Müller W, Stratz T, and Candelario-Jalil E (2004b) Expression of 5- $\mathrm{HT}_{3 \mathrm{~A}}$ receptors in cells of the immune system. Scand J Rheumatol Suppl 119:9-11.

Filip M, Baran L, Siwanowicz J, Chojnacka-Wójcik E, and Przegaliński E (1992) The anxiolytic-like effects of 5-hydroxytryptamine3 $\left(5-\mathrm{HT}_{3}\right)$ receptor antagonists. $\mathrm{Pol}$ $J$ Pharmacol Pharm 44:261-269.

Fletcher S and Barnes NM (1999) Autoradiographic localization of the [3H]-(S)zacopride labelled 5- $\mathrm{HT}_{3}$ receptor in porcine brain. Neurosci Lett 269:91-94.

Fond G, Loundou A, Hamdani N, Boukouaci W, Dargel A, Oliveira J, Roger M, Tamouza R, Leboyer M, and Boyer L (2014) Anxiety and depression comorbidities in irritable bowel syndrome (IBS): a systematic review and meta-analysis. Eur Arch Psychiatry Clin Neurosci 264:651-660.

Funahashi M, Mitoh Y, and Matsuo R (2004) Activation of presynaptic 5-HT 3 receptors facilitates glutamatergic synaptic inputs to area postrema neurons in rat brain slices. Methods Find Exp Clin Pharmacol 26:615-622.

Gaboyard-Niay S (2013) inventor, Sensorion, assignee. Methods for treating vestibulotoxicity. French patent EP2854829A1

Gehlert DR, Gackenheimer SL, Wong DT, and Robertson DW (1991) Localization of $5-\mathrm{HT}_{3}$ receptors in the rat brain using [3H]LY278584. Brain Res 553:149-154

George M, Al-Duaij N, O'Donnell KA, and Shannon MW (2008) Obtundation and seizure following ondansetron overdose in an infant. Clin Toxicol (Phila) 46 $1064-1066$

Gharedaghi MH, Seyedabadi M, Ghia J-E, Dehpour AR, and Rahimian R (2014) The role of different serotonin receptor subtypes in seizure susceptibility. Exp Brain Res 232:347-367.

Gholipour T, Ghasemi M, Riazi K, Ghaffarpour M, and Dehpour AR (2010) Seizure susceptibility alteration through $\left.5-\mathrm{HT}_{3}\right)$ receptor: modulation by nitric oxide. Seizure 19:17-22.

Gill CH, Peters JA, and Lambert JJ (1995) An electrophysiological investigation of the properties of a murine recombinant $5-\mathrm{HT}_{3}$ receptor stably expressed in HEK 293 cells. Br J Pharmacol 114:1211-1221.

Gleeson JG, duPlessis AJ, Barnes PD, and Riviello JJ Jr (1998) Cyclosporin A acute encephalopathy and seizure syndrome in childhood: clinical features and risk of seizure recurrence. J Child Neurol 13:336-344

Glennon RA, Daoud MK, Dukat M, Teitler M, Herrick-Davis K, Purohit A, and Syed $\mathrm{H}$ (2003) Arylguanidine and arylbiguanide binding at $5-\mathrm{HT}_{3}$ serotonin receptors: a QSAR study. Bioorg Med Chem 11:4449-4454.

Glennon RA, Ismaiel AE, McCarthy BG, and Peroutka SJ (1989) Binding of arylpiperazines to $5-\mathrm{HT}_{3}$ serotonin receptors: results of a structure-affinity study. Eur $J$ Pharmacol 168:387-392.

Gonzales D, Rennard SI, Nides M, Oncken C, Azoulay S, Billing CB, Watsky EJ, Gong J, Williams KE, and Reeves KR; Varenicline Phase 3 Study Group (2006) Varenicline, an alpha4beta2 nicotinic acetylcholine receptor partial agonist, vs sustained-release bupropion and placebo for smoking cessation: a randomized controlled trial. JAMA 296:47-55.

Goudakos JK, Markou KD, Franco-Vidal V, Vital V, Tsaligopoulos M, and Darrouzet $\mathrm{V}$ (2010) Corticosteroids in the treatment of vestibular neuritis: a systematic review and meta-analysis. Otol Neurotol 31:183-189.

Grace AA (2016) Dysregulation of the dopamine system in the pathophysiology of schizophrenia and depression. Nat Rev Neurosci 17:524-532.

Grant KA, Hellevuo K, and Tabakoff B (1994) The 5-HT 3 antagonist MDL-72222 exacerbates ethanol withdrawal seizures in mice. Alcohol Clin Exp Res 18:410-414.

Green MF, Kern RS, and Heaton RK (2004) Longitudinal studies of cognition and functional outcome in schizophrenia: implications for MATRICS. Schizophr Res $\mathbf{7 2}$ 41-51.
Greenwood-Van Meerveld B, Gibson M, Gunter W, Shepard J, Foreman R, and Myers D (2001) Stereotaxic delivery of corticosterone to the amygdala modulates colonic sensitivity in rats. Brain Res 893:135-142.

Gulyás AI, Acsády L, and Freund TF (1999) Structural basis of the cholinergic and serotonergic modulation of GABAergic neurons in the hippocampus. Neurochem Int 34:359-372.

Gunthorpe MJ and Lummis SC (1999) Diltiazem causes open channel block of recombinant 5- $\mathrm{HT}_{3}$ receptors. J Physiol 519:713-722.

Gupta D, Prabhakar V, and Radhakrishnan M (2016) $5 \mathrm{HT}_{3}$ receptors: target for new antidepressant drugs. Neurosci Biobehav Rev 64:311-325.

Gupta D, Radhakrishnan M, and Kurhe Y (2014a) $5 \mathrm{HT}_{3}$ receptor antagonist (ondansetron) reverses depressive behavior evoked by chronic unpredictable stress in mice: modulation of hypothalamic-pituitary-adrenocortical and brain serotonergic system. Pharmacol Biochem Behav 124:129-136.

Gupta D, Radhakrishnan M, and Kurhe Y (2015) Effect of a novel 5-HT 3 receptor antagonist $4 \mathrm{i}$, in corticosterone-induced depression-like behavior and oxidative stress in mice. Steroids 96:95-102.

Gupta D, Radhakrishnan M, Kurhe Y, Thangaraj D, Prabhakar V, and Kanade P (2014b) Antidepressant-like effects of a novel 5- $\mathrm{HT}_{3}$ receptor antagonist $6 \mathrm{z}$ in acute and chronic murine models of depression. Acta Pharmacol Sin 35:1493-1503.

Hammer C, Cichon S, Mühleisen TW, Haenisch B, Degenhardt F, Mattheisen M, Breuer R, Witt SH, Strohmaier J, Oruc L, et al. (2012) Replication of functional serotonin receptor type $3 \mathrm{~A}$ and $\mathrm{B}$ variants in bipolar affective disorder: a European multicenter study. Transl Psychiatry 2:e103.

Hargreaves AC, Gunthorpe MJ, Taylor CW, and Lummis SC (1996) Direct inhibition of 5-hydroxytryptamine 3 receptors by antagonists of L-type $\mathrm{Ca}^{2+}$ channels. $\mathrm{Mol}$ Pharmacol 50:1284-1294.

Harmer CJ, Reid CB, Ray MK, Goodwin GM, and Cowen PJ (2006) 5HT( ${ }_{3}$ ) antagonism abolishes the emotion potentiated startle effect in humans. Psychopharmacology (Berl) 186:18-24.

Harvey PD, Green MF, Keefe RS, and Velligan DI (2004) Cognitive functioning in schizophrenia: a consensus statement on its role in the definition and evaluation of effective treatments for the illness. J Clin Psychiatry 65:361-372.

Hashimoto K (2015) Tropisetron and its targets in Alzheimer's disease. Expert Opin Ther Targets 19:1-5.

Hashimoto K, Iyo M, Freedman R, and Stevens KE (2005) Tropisetron improves deficient inhibitory auditory processing in DBA/2 mice: role of $\alpha 7$ nicotinic acetylcholine receptors. Psychopharmacology (Berl) 183:13-19.

Hatsukami DK, Jensen J, Brauer LH, Mooney M, Schulte S, Sofuoglu M, and Pentel PR (2003) Lack of effect of $5 \mathrm{HT}_{3}$ antagonist in mediating subjective and behavioral responses to cotinine. Pharmacol Biochem Behav 75:1-7.

Hazlett EA, Rothstein EG, Ferreira R, Silverman JM, Siever LJ, and Olincy A (2015) Sensory gating disturbances in the spectrum: similarities and differences in schizotypal personality disorder and schizophrenia. Schizophr Res 161:283-290.

Heimes K, Feistel B, and Verspohl EJ (2009) Impact of the 5-HT $\mathrm{H}_{3}$ receptor channel system for insulin secretion and interaction of ginger extracts. Eur $J$ Pharmacol 624:58-65.

Hermann B, Wetzel CH, Pestel E, Zieglgänsberger W, Holsboer F, and Rupprecht R (1996) Functional antagonistic properties of clozapine at the $5-\mathrm{HT}_{3}$ receptor Biochem Biophys Res Commun 225:957-960.

Higgins GA, Tomkins DM, Fletcher PJ, and Sellers EM (1992) Effect of drugs influencing 5-HT function on ethanol drinking and feeding behaviour in rats: studies using a drinkometer system. Neurosci Biobehav Rev 16:535-552.

Hirata T, Keto Y, Funatsu T, Akuzawa S, and Sasamata M (2007) Evaluation of the pharmacological profile of ramosetron, a novel therapeutic agent for irritable bowel syndrome. J Pharmacol Sci 104:263-273.

Hope AG, Peters JA, Brown AM, Lambert JJ, and Blackburn TP (1996) Characterization of a human 5-hydroxytryptamine3 receptor type A (h5-HT3R-AS) subunit stably expressed in HEK 293 cells. Br J Pharmacol 118:1237-1245.

Hornung J-P and Celio MR (1992) The selective innervation by serotoninergic axons of calbindin-containing interneurons in the neocortex and hippocampus of the marmoset. J Comp Neurol 320:457-467.

Huang M, Felix AR, Kwon S, Lowe D, Wallace T, Santarelli L, and Meltzer HY (2014) The alpha-7 nicotinic receptor partial agonist/5- $\mathrm{HT}_{3}$ antagonist RG3487 enhances cortical and hippocampal dopamine and acetylcholine release. Psychopharmacology (Berl) 231:2199-2210.

Hussy N, Lukas W, and Jones KA (1994) Functional properties of a cloned 5-hydroxytryptamine ionotropic receptor subunit: comparison with native mouse receptors. J Physiol 481:311-323.

Iidaka T, Ozaki N, Matsumoto A, Nogawa J, Kinoshita Y, Suzuki T, Iwata N, Yamamoto Y, Okada T, and Sadato N (2005) A variant C178T in the regulatory region of the serotonin receptor gene HTR3A modulates neural activation in the human amygdala. J Neurosci 25:6460-6466.

Imperato A and Angelucci L (1989) 5 - $\mathrm{HT}_{3}$ receptors control dopamine release in the nucleus accumbens of freely moving rats. Neurosci Lett 101:214-217.

Invernizzi R, Pozzi L, and Samanin R (1995) Selective reduction of extracellular dopamine in the rat nucleus accumbens following chronic treatment with DAU 6215, a 5- $\mathrm{HT}_{3}$ receptor antagonist. Neuropharmacology 34:211-215.

Ishikawa M, Sakata M, Toyohara J, Oda K, Ishii K, Wu J, Yoshida T, Iyo M, Ishiwata $\mathrm{K}$, and Hashimoto $\mathrm{K}$ (2011) Occupancy of $\alpha 7$ nicotinic acetylcholine receptors in the brain by tropisetron: a positron emission tomography study using [(11)C]CHIBA1001 in healthy human subjects. Clin Psychopharmacol Neurosci 9:111-116.

Jacob RG and Furman JM (2001) Psychiatric consequences of vestibular dysfunction. Curr Opin Neurol 14:41-46.

Jain S, Agarwal NB, Mediratta PK, and Sharma KK (2012) Evaluation of anticonvulsant and nootropic effect of ondansetron in mice. Hum Exp Toxicol 31:905-912.

Jajodia A, Kaur H, Kumari K, Gupta M, Baghel R, Srivastava A, Sood M, Chadda RK, Jain S, and Kukreti R (2015) Evidence for schizophrenia susceptibility alleles in the Indian population: an association of neurodevelopmental genes in casecontrol and familial samples. Schizophr Res 162:112-117. 
Jarvis GE, Barbosa R, and Thompson AJ (2016) Noncompetitive inhibition of 5-HT 3 receptors by citral, linalool, and eucalyptol revealed by nonlinear mixed-effects modeling. J Pharmacol Exp Ther 356:549-562.

Javadi-Paydar M, Zakeri M, Norouzi A, Rastegar H, Mirazi N, and Dehpour AR (2012) Involvement of nitric oxide in granisetron improving effect on scopolamineinduced memory impairment in mice. Brain Res 1429:61-71.

Jeggo RD, Kellett DO, Wang Y, Ramage AG, and Jordan D (2005) The role of central $5-\mathrm{HT}_{3}$ receptors in vagal reflex inputs to neurones in the nucleus tractus solitarius of anaesthetized rats. J Physiol 566:939-953.

Johnson BA and Ait-Daoud N (2000) Neuropharmacological treatments for alcoholism: scientific basis and clinical findings. Psychopharmacology (Berl) 149.327-344

Johnson BA, Ait-Daoud N, Elkashef AM, Smith EV, Kahn R, Vocci F, Li S-H, and Bloch DA; Methamphetamine Study Group (2008) A preliminary randomized, double-blind, placebo-controlled study of the safety and efficacy of ondansetron in the treatment of methamphetamine dependence. Int $J$ Neuropsychopharmacol 11:1-14.

Johnson BA, Ait-Daoud N, and Prihoda TJ (2000a) Combining ondansetron and naltrexone effectively treats biologically predisposed alcoholics: from hypotheses to preliminary clinical evidence. Alcohol Clin Exp Res 24:737-742.

Johnson BA, Roache JD, Ait-Daoud N, Zanca NA, and Velazquez M (2002) Ondansetron reduces the craving of biologically predisposed alcoholics. Psychopharmacology (Berl) 160:408-413.

Johnson BA, Roache JD, Javors MA, DiClemente CC, Cloninger CR, Prihoda TJ Bordnick PS, Ait-Daoud N, and Hensler J (2000b) Ondansetron for reduction of drinking among biologically predisposed alcoholic patients: a randomized controlled trial. JAMA 284:963-971.

Jones BJ, Costall B, Domeney AM, Kelly ME, Naylor RJ, Oakley NR, and Tyers MB (1988) The potential anxiolytic activity of GR38032F, a $5-\mathrm{HT}_{3}$-receptor antagonist. Br J Pharmacol 93:985-993.

Kagami Y, Shigenobu S, and Watanabe S (1992) Neuroprotective effect of 5- $\mathrm{HT}_{3}$ receptor antagonist on ischemia-induced decrease in CA1 field potential in rat hippocampal slices. Eur J Pharmacol 224:51-56.

Kankaanpää A, Lillsunde P, Ruotsalainen M, Ahtee L, and Seppâlä T (1996) 5-HT receptor antagonist MDL 72222 dose-dependently attenuates cocaine- and amphetamine-induced elevations of extracellular dopamine in the nucleus accumbens and the dorsal striatum. Pharmacol Toxicol 78:317-321.

Kankaanpää A, Meririnne E, and Seppälä T (2002) 5- $\mathrm{HT}_{3}$ receptor antagonist MDL 72222 attenuates cocaine- and mazindol-, but not methylphenidate-induced neurochemical and behavioral effects in the rat. Psychopharmacology (Berl) $\mathbf{1 5 9}$ 341-350.

Kantrow SP, Gierman JL, Jaligam VR, Zhang P, Piantadosi CA, Summer WR, and Lancaster JR Jr (2000) Regulation of tumor necrosis factor cytotoxicity by calcineurin. FEBS Lett 483:119-124.

Katsurabayashi S, Kubota H, Tokutomi N, and Akaike N (2003) A distinct distribution of functional presynaptic 5-HT receptor subtypes on GABAergic nerve terminals projecting to single hippocampal CA1 pyramidal neurons. Neuropharmacology 44:1022-1030.

Kawa K (1994) Distribution and functional properties of $5-\mathrm{HT}_{3}$ receptors in the rat hippocampal dentate gyrus: a patch-clamp study. J Neurophysiol 71:1935-1947.

Kelley SP, Bratt AM, and Hodge CW (2003a) Targeted gene deletion of the 5- $\mathrm{HT}_{3 \mathrm{~A}}$ receptor subunit produces an anxiolytic phenotype in mice. Eur J Pharmacol 461: $19-25$.

Kelley SP, Dunlop JI, Kirkness EF, Lambert JJ, and Peters JA (2003b) A cytoplasmic region determines single-channel conductance in $5-\mathrm{HT}_{3}$ receptors. Nature 424: 321-324.

Khalifeh S, Fakhfouri G, Mehr SE, Mousavizadeh K, Dehpour AR, Khodagholi F, Kazmi S, and Rahimian R (2015) Beyond the 5-HT $\mathrm{H}_{3}$ receptors: a role for $\alpha 7 \mathrm{nACh}$ receptors in neuroprotective aspects of tropisetron. Hum Exp Toxicol 34:922-931.

Khan GM, Tong M, Jhun M, Arora K, and Nichols RA (2010) $\beta$-Amyloid activates presynaptic $\alpha 7$ nicotinic acetylcholine receptors reconstituted into a model nerve cell system: involvement of lipid rafts. Eur J Neurosci 31:788-796.

Kilpatrick GJ, Butler A, Burridge J, and Oxford AW (1990) 1-(m-chlorophenyl) biguanide, a potent high affinity $5-\mathrm{HT}_{3}$ receptor agonist. Eur $J$ Pharmacol 182 193-197.

Kilpatrick LA, Labus JS, Coveleskie K, Hammer C, Rappold G, Tillisch K, Bueller JA, Suyenobu B, Jarcho JM, McRoberts JA, et al. (2011) The HTR3A polymorphism c. $-42 \mathrm{C}>\mathrm{T}$ is associated with amygdala responsiveness in patients with irritable bowel syndrome. Gastroenterology 140:1943-1951.

Kim JY, Lee JW, Kim M, Kim MJ, and Kim DK (2018) Association of idiopathic sudden sensorineural hearing loss with affective disorders. JAMA Otolaryngol Head Neck Surg 144:614-621.

Kitagawa H, Takenouchi T, Azuma R, Wesnes KA, Kramer WG, Clody DE, and Burnett AL (2003) Safety, pharmacokinetics, and effects on cognitive function of multiple doses of GTS-21 in healthy, male volunteers. Neuropsychopharmacology 28:542-551.

Klee CB, Ren H, and Wang X (1998) Regulation of the calmodulin-stimulated protein phosphatase, calcineurin. J Biol Chem 273:13367-13370.

Klein RL, Sanna E, McQuilkin SJ, Whiting PJ, and Harris RA (1994) Effects of 5-HT receptor antagonists on binding and function of mouse and human GABAA receptors. Eur J Pharmacol 268:237-246.

Kohnomi S, Suemaru K, Goda M, Choshi T, Hibino S, Kawasaki H, and Araki H (2010) Ameliorating effects of tropisetron on dopaminergic disruption of prepulse inhibition via the $\alpha(7)$ nicotinic acetylcholine receptor in Wistar rats. Brain Res 1353:152-158.

Komoto S and Miura S (2006) Antagonists of the type 3 serotonin receptor $\left(5-\mathrm{HT}_{3}\right)$ in IBS. Nihon Rinsho 64:1487-1490.

Kondo M, Nakamura Y, Ishida Y, Yamada T, and Shimada S (2013) The 5-HT $\mathrm{HA}_{3 \mathrm{~A}}$ receptor is essential for fear extinction. Learn Mem 21:1-4.

Konings PN, Makkink WK, van Delft AM, and Ruigt GS (1994a) Reversal by NGF of cytostatic drug-induced reduction of neurite outgrowth in rat dorsal root ganglia in vitro. Brain Res 640:195-204.
Konings PNM, Philipsen RLA, Veeneman GH, and Ruigt GS (1994b) $\alpha$-sialyl cholesterol increases laminin in Schwann cell cultures and attenuates cytostatic druginduced reduction of laminin. Brain Res 654:118-128.

Kos T, Popik P, Pietraszek M, Schäfer D, Danysz W, Dravolina O, Blokhina E, Galankin T, and Bespalov AY (2006) Effect of 5- $\mathrm{HT}_{3}$ receptor antagonist MDL 72222 on behaviors induced by ketamine in rats and mice. Eur Neuropsychopharmacol 16:297-310.

Koulu M, Sjöholm B, Lappalainen J, and Virtanen R (1989) Effects of acute GR38032F (odansetron), a $5-\mathrm{HT}_{3}$ receptor antagonist, on dopamine and serotonin metabolism in mesolimbic and nigrostriatal dopaminergic neurons. Eur J Pharmacol 169:321-324.

Koyama S, Kubo C, Rhee J-S, and Akaike N (1999) Presynaptic serotonergic inhibition of GABAergic synaptic transmission in mechanically dissociated rat basolateral amygdala neurons. J Physiol 518:525-538.

Krabbe G, Matyash V, Pannasch U, Mamer L, Boddeke HWGM, and Kettenmann H (2012) Activation of serotonin receptors promotes microglial injury-induced motility but attenuates phagocytic activity. Brain Behav Immun 26:419-428.

Kranzler HR, Pierucci-Lagha A, Feinn R, and Hernandez-Avila C (2003) Effects of ondansetron in early- versus late-onset alcoholics: a prospective, open-label study. Alcohol Clin Exp Res 27:1150-1155.

Kriz J and Lalancette-Hébert M (2009) Inflammation, plasticity and real-time imaging after cerebral ischemia. Acta Neuropathol 117:497-509.

Krzywkowski K, Davies PA, Feinberg-Zadek PL, Bräuner-Osborne H, and Jensen AA (2008) High-frequency HTR3B variant associated with major depression dramatically augments the signaling of the human $5-\mathrm{HT}_{3 \mathrm{AB}}$ receptor. Proc Natl Acad Sci USA 105:722-727.

Kuhn M, Heman-Ackah SE, Shaikh JA, and Roehm PC (2011) Sudden sensorineural hearing loss: a review of diagnosis, treatment, and prognosis. Trends Amplif 15:91-105.

Kujawa SG and Liberman MC (2009) Adding insult to injury: cochlear nerve degeneration after "temporary" noise-induced hearing loss. $J$ Neurosci 29: 14077-14085.

Lambert JJ, Peters JA, Hales TG, and Dempster J (1989) The properties of 5-HT receptors in clonal cell lines studied by patch-clamp techniques. $\mathrm{Br} J$ Pharmacol 97:27-40

LeDoux JE (2015) Anxious: Using the Brain to Understand and Treat Fear and Anxiety, Penguin, New York.

Lee BH, Jeong SM, Lee JH, Kim JH, Yoon IS, Lee JH, Choi SH, Lee SM, Chang CG, Kim HC, et al. (2005a) Quercetin inhibits the 5-hydroxytryptamine type 3 receptormediated ion current by interacting with pre-transmembrane domain I [published correction appears in Mol Cells (2005) 20:452]. Mol Cells 20:69-73.

Lee HJ, Ban JY, and Seong YH (2005b) Blockade of 5-HT( ${ }_{3}$ ) receptor with MDL7222 and Y25130 reduces hydrogen peroxide-induced neurotoxicity in cultured rat cortical cells. Life Sci 78:294-300.

Lee JH, Lee YJ, Kang SW, Kim Y, Shin M, Hong M, Seo EK, Kim SH, Nah SY, and Bae $\mathrm{H}$ (2010) Effects of protostane-type triterpenoids on the 5-HT 3 receptormediated ion current in Xenopus oocytes. Brain Res 1331:20-27.

Lee JH, Lee YJ, Shin JK, Nam JW, Nah SY, Kim SH, Jeong JH, Kim Y, Shin M, Hong M, et al. (2009) Effects of triterpenoids from Poria cocos Wolf on the serotonin type 3A receptor-mediated ion current in Xenopus oocytes. Eur J Pharmacol 615:27-32.

Lee Y, Lee S-R, Choi SS, Yeo H-G, Chang K-T, and Lee HJ (2014) Therapeutically targeting neuroinflammation and microglia after acute ischemic stroke. BioMed Res Int 2014:297241.

Lennertz L, Wagner M, Frommann I, Schulze-Rauschenbach S, Schuhmacher A Kühn K-U, Pukrop R, Klosterkötter J, Wölwer W, Gaebel W, et al. (2010) A coding variant of the novel serotonin receptor subunit $5-\mathrm{HT}_{3 \mathrm{E}}$ influences sustained attention in schizophrenia patients. Eur Neuropsychopharmacol 20:414-420.

Lennertz L, Wagner M, Grabe HJ, Franke PE, Guttenthaler V, Rampacher F, Schulze-Rauschenbach S, Vogeley A, Benninghoff J, Ruhrmann S, et al. (2014) 5$\mathrm{HT}_{3}$ receptor influences the washing phenotype and visual organization in obsessive-compulsive disorder supporting $5-\mathrm{HT}_{3}$ receptor antagonists as nove treatment option. Eur Neuropsychopharmacol 24:86-94.

Levin ED, Bettegowda C, Blosser J, and Gordon J (1999) AR-R17779, and alpha7 nicotinic agonist, improves learning and memory in rats. Behav Pharmacol 10: $675-680$.

Levitt P and Moore RY (1978) Noradrenaline neuron innervation of the neocortex in the rat. Brain Res 139:219-231.

Li B, Wang L, Sun Z, Zhou Y, Shao D, Zhao J, Song Y, Lv J, Dong X, Liu C, et al. (2014) The anticonvulsant effects of SR 57227 on pentylenetetrazole-induced seizure in mice. PLoS One 9:e93158.

Li Q, Guo D, Dong Z, Zhang W, Zhang L, Huang SM, Polli JE, and Shu Y (2013) Ondansetron can enhance cisplatin-induced nephrotoxicity via inhibition of multiple toxin and extrusion proteins (MATEs). Toxicol Appl Pharmacol 273:100-109.

Liang X, Arvanov VL, and Wang RY (1998) Inhibition of NMDA-receptor mediated response in the rat medial prefrontal cortical pyramidal cells by the $5-\mathrm{HT}_{3}$ receptor agonist SR 57227A and 5-HT: intracellular studies. Synapse 29:257-268.

Lilja AM, Porras O, Storelli E, Nordberg A, and Marutle A (2011) Functional interactions of fibrillar and oligomeric amyloid- $\beta$ with alpha7 nicotinic receptors in Alzheimer's disease. J Alzheimers Dis 23:335-347.

Lin FR, Metter EJ, O'Brien RJ, Resnick SM, Zonderman AB, and Ferrucci L (2011a) Hearing loss and incident dementia. Arch Neurol 68:214-220.

Lin HW, Furman AC, Kujawa SG, and Liberman MC (2011b) Primary neural degeneration in the Guinea pig cochlea after reversible noise-induced threshold shift. $J$ Assoc Res Otolaryngol 12:605-616.

Linthicum FH Jr, Doherty J, and Berliner KI (2013) Idiopathic sudden sensorineural hearing loss: vascular or viral? Otolaryngol Head Neck Surg 149:914-917.

Liu AK, Chang RC, Pearce RK, and Gentleman SM (2015) Nucleus basalis of Meynert revisited: anatomy, history and differential involvement in Alzheimer's and Parkinson's disease. Acta Neuropathol 129:527-540.

Liu FC, Lee HC, Liao CC, Li AH, and Yu HP (2016) Tropisetron protects against acetaminophen-induced liver injury via suppressing hepatic oxidative stress and 
modulating the activation of JNK/ERK MAPK pathways. BioMed Res Int 2016 1952947.

Liu F-C, Yu H-P, Hwang T-L, and Tsai Y-F (2012) Protective effect of tropisetron on rodent hepatic injury after trauma-hemorrhagic shock through P38 MAPKdependent hemeoxygenase-1 expression. PLoS One 7:e53203.

Lochner M and Thompson AJ (2016) The muscarinic antagonists scopolamine and atropine are competitive antagonists at $5-\mathrm{HT}_{3}$ receptors. Neuropharmacology 108: $220-228$.

Lummis SC, Kilpatrick GJ, and Martin IL (1990) Characterization of 5-HT 3 receptors in intact N1E-115 neuroblastoma cells. Eur J Pharmacol 189:223-227.

Lummis SC, Sepúlveda MI, Kilpatrick GJ, and Baker J (1993) Characterization of $[3 \mathrm{H}]$ meta-chlorophenylbiguanide binding to $5-\mathrm{HT}_{3}$ receptors in $\mathrm{N} 1 \mathrm{E}-115$ neuroblastoma cells. Eur J Pharmacol 243:7-11.

Lummis SC, Thompson AJ, Bencherif M, and Lester HA (2011) Varenicline is a potent agonist of the human 5-hydroxytryptamine3 receptor. $J$ Pharmacol Exp Ther 339:125-131.

Ma QP, Yin GF, Ai MK, and Han JS (1991) Serotonergic projections from the nucleus raphe dorsalis to the amygdala in the rat. Neurosci Lett 134:21-24.

MacKenzie NE, Kowalchuk C, Agarwal SM, Costa-Dookhan KA, Caravaggio F, Gerretsen P, Chintoh A, Remington GJ, Taylor VH, Müeller DJ, et al. (2018) Antipsychotics, metabolic adverse effects, and cognitive function in schizophrenia Front Psychiatry 9:622.

Macor JE, Gurley D, Lanthorn T, Loch J, Mack RA, Mullen G, Tran O, Wright N, and Gordon $\mathrm{JC}$ (2001) The 5- $\mathrm{HT}_{3}$ antagonist tropisetron (ICS 205-930) is a potent and selective $\alpha 7$ nicotinic receptor partial agonist. Bioorg Med Chem Lett 11:319-321.

Mandalà M and Nuti D (2009) Long-term follow-up of vestibular neuritis. Ann N Y Acad Sci 1164:427-429.

Manzari L, Burgess AM, MacDougall HG, and Curthoys IS (2013) Vestibular function after vestibular neuritis. Int $J$ Audiol 52:713-718.

Maricq AV, Peterson AS, Brake AJ, Myers RM, and Julius D (1991) Primary structure and functional expression of the $5 \mathrm{HT}_{3}$ receptor, a serotonin-gated ion channel. Science 254:432-437.

Martin P, Gozlan H, and Puech AJ (1992) 5- $\mathrm{HT}_{3}$ receptor antagonists reverse helpless behaviour in rats. Eur $J$ Pharmacol 212:73-78.

Mastorakos G, Chrousos GP, and Weber JS (1993) Recombinant interleukin-6 activates the hypothalamic-pituitary-adrenal axis in humans. $J$ Clin Endocrinol Metab 77:1690-1694

Maura G, Andrioli GC, Cavazzani P, and Raiteri M (1992) 5-Hydroxytryptamine3 receptors sited on cholinergic axon terminals of human cerebral cortex mediate inhibition of acetylcholine release. J Neurochem 58:2334-2337.

Mayer EA, Berman S, Derbyshire SWG, Suyenobu B, Chang L, Fitzgerald L Mandelkern M, Hamm L, Vogt B, and Naliboff BD (2002) The effect of the 5-HT receptor antagonist, alosetron, on brain responses to visceral stimulation in irritable bowel syndrome patients. Aliment Pharmacol Ther 16:1357-1366.

McMahon LL and Kauer JA (1997) Hippocampal interneurons are excited via serotonin-gated ion channels. $J$ Neurophysiol 78:2493-2502.

Merchant SN, Adams JC, and Nadol JB Jr (2005) Pathology and pathophysiology of idiopathic sudden sensorineural hearing loss. Otol Neurotol 26:151-160.

Mertz H, Morgan V, Tanner G, Pickens D, Price R, Shyr Y, and Kessler R (2000) Regional cerebral activation in irritable bowel syndrome and control subjects with painful and nonpainful rectal distention. Gastroenterology 118:842-848.

Mishra A and Goel RK (2016) Chronic 5- $\mathrm{HT}_{3}$ receptor antagonism ameliorates seizures and associated memory deficit in pentylenetetrazole-kindled mice. Neuroscience 339:319-328.

Miyake A, Mochizuki S, Takemoto Y, and Akuzawa S (1995) Molecular cloning of human 5-hydroxytryptamine3 receptor: heterogeneity in distribution and function among species. Mol Pharmacol 48:407-416.

Morrison TR, Ricci LA, and Melloni RH Jr (2015) Aggression and anxiety in adolescent AAS-treated hamsters: a role for $5 \mathrm{HT}_{3}$ receptors. Pharmacol Biochem Behav 134:85-91.

Müller W, Fiebich BL, and Stratz T (2006) New treatment options using 5- $\mathrm{HT}_{3}$ receptor antagonists in rheumatic diseases. Curr Top Med Chem 6:2035-2042.

Mylecharane EJ (1996) Ventral tegmental area 5-HT receptors: mesolimbic dopamine release and behavioural studies. Behav Brain Res 73:1-5.

Nagakura Y, Akuzawa S, Miyata K, Kamato T, Suzuki T, Ito H, and Yamaguchi T (1999) Pharmacological properties of a novel gastrointestinal prokinetic benzamide selective for human 5- $\mathrm{HT}_{4}$ receptor versus human 5- $\mathrm{HT}_{3}$ receptor. Pharmacol Res 39:375-382.

Naidu PS and Kulkarni SK (2001) Reversal of neuroleptic-induced orofacial dyskinesia by $5-\mathrm{HT}_{3}$ receptor antagonists. Eur $J$ Pharmacol 420:113-117.

Nakagawa Y, Ishima T, and Takashima $\mathrm{T}$ (1998) The 5- $\mathrm{HT}_{3}$ receptor agonist attenuates the action of antidepressants in the forced swim test in rats. Brain Res 786:189-193.

Naliboff BD, Berman S, Chang L, Derbyshire SWG, Suyenobu B, Vogt BA, Mandelkern M, and Mayer EA (2003) Sex-related differences in IBS patients: central processing of visceral stimuli. Gastroenterology 124:1738-1747.

Naliboff BD, Derbyshire SW, Munakata J, Berman S, Mandelkern M, Chang L, and Mayer EA (2001) Cerebral activation in patients with irritable bowel syndrome and control subjects during rectosigmoid stimulation. Psychosom Med 63:365-375.

Nestler EJ and Carlezon WA Jr (2006) The mesolimbic dopamine reward circuit in depression. Biol Psychiatry 59:1151-1159.

Neve KA, Neve RL, Fidel S, Janowsky A, and Higgins GA (1991) Increased abundance of alternatively spliced forms of D2 dopamine receptor mRNA after denervation. Proc Natl Acad Sci USA 88:2802-2806.

Niesler B, Flohr T, Nöthen MM, Fischer C, Rietschel M, Franzek E, Albus M, Propping P, and Rappold GA (2001) Association between the 5' UTR variant C178T of the serotonin receptor gene HTR3A and bipolar affective disorder. Pharmacogenetics 11:471-475.

Niesler B, Walstab J, Combrink S, Möller D, Kapeller J, Rietdorf J, Bönisch H, Göthert M, Rappold G, and Brüss M (2007) Characterization of the novel human serotonin receptor subunits 5- $\mathrm{HT}_{3 \mathrm{C}}, 5-\mathrm{HT}_{3 \mathrm{D}}$, and 5- $\mathrm{HT}_{3 \mathrm{E}}$. Mol Pharmacol 72:8-17.
Noroozian M, Ghasemi S, Hosseini S-M-R, Modabbernia A, Khodaie-Ardakani M-R, Mirshafiee O, Farokhnia M, Tajdini M, Rezaei F, Salehi B, et al. (2013) A placebocontrolled study of tropisetron added to risperidone for the treatment of negative symptoms in chronic and stable schizophrenia. Psychopharmacology (Berl) 228:595-602.

Ohno M and Watanabe S (1997) Differential effects of 5- $\mathrm{HT}_{3}$ receptor antagonism on working memory failure due to deficiency of hippocampal cholinergic and glutamatergic transmission in rats. Brain Res 762:211-215.

Ohno Y, Imaki J, Mae Y, Takahashi T, and Tatara A (2011) Serotonergic modulation of extrapyramidal motor disorders in mice and rats: role of striatal $5-\mathrm{HT}_{3}$ and 5- $\mathrm{HT}_{6}$ receptors. Neuropharmacology 60:201-208.

Ohno Y, Shimizu S, Tokudome K, Kunisawa N, and Sasa M (2015) New insight into the therapeutic role of the serotonergic system in Parkinson's disease. Prog Neurobiol 134:104-121.

Olincy A, Harris JG, Johnson LL, Pender V, Kongs S, Allensworth D, Ellis J, Zerbe GO, Leonard S, Stevens KE, et al. (2006) Proof-of-concept trial of an alpha7 nicotinic agonist in schizophrenia. Arch Gen Psychiatry 63:630-638.

Olsson T, Viitanen M, Asplund K, Eriksson S, and Hägg E (1990) Prognosis after stroke in diabetic patients. A controlled prospective study. Diabetologia 33: 244-249.

Ortega JE, Mendiguren A, Pineda J, and Meana JJ (2012) Regulation of central noradrenergic activity by $\left.5-\mathrm{HT}_{3}\right)$ receptors located in the locus coeruleus of the rat. Neuropharmacology 62:2472-2479.

Osonoe K, Mori N, Suzuki K, and Osonoe M (1994) Antiepileptic effects of inhibitors of nitric oxide synthase examined in pentylenetetrazol-induced seizures in rats. Brain Res 663:338-340.

Pallanti S, Bernardi S, Antonini S, Singh N, and Hollander E (2009) Ondansetron augmentation in treatment-resistant obsessive-compulsive disorder: a preliminary, single-blind, prospective study. CNS Drugs 23:1047-1055.

Parham K and Dyhrfjeld-Johnsen J (2016) Outer hair cell molecular protein, prestin, as a serum biomarker for hearing loss: proof of concept. Otol Neurotol 37 $1217-1222$

Patel A, Mittal S, Manchanda S, and Puliyel JM (2011) Ondansetron-induced dystonia, hypoglycemia, and seizures in a child. Ann Pharmacother 45: 7 .

Patel AR, Ritzel R, McCullough LD, and Liu F (2013) Microglia and ischemic stroke: a double-edged sword. Int J Physiol Pathophysiol Pharmacol 5:73-90.

Payandemehr B, Bahremand A, Rahimian R, Ziai P, Amouzegar A, Sharifzadeh M, and Dehpour AR (2012) 5-HT( $\left.{ }_{3}\right)$ receptor mediates the dose-dependent effects of citalopram on pentylenetetrazole-induced clonic seizure in mice: involvement of nitric oxide. Epilepsy Res 101:217-227.

Pehrson AL and Sanchez C (2014) Serotonergic modulation of glutamate neurotransmission as a strategy for treating depression and cognitive dysfunction. CNS Spectr 19:121-133

Pei Q, Zetterström T, Leslie RA, and Grahame-Smith DG (1993) 5-HT $\mathrm{HT}_{3}$ receptor antagonists inhibit morphine-induced stimulation of mesolimbic dopamine release and function in the rat. Eur $J$ Pharmacol 230:63-68.

Perroud N, Zewdie S, Stenz L, Adouan W, Bavamian S, Prada P, Nicastro R, Hasler R, Nallet A, Piguet C, et al. (2016) Methylation of serotonin receptor 3A in ADHD, borderline personality, and bipolar disorders: link with severity of the disorders and childhood maltreatment. Depress Anxiety 33:45-55.

Perry EK, Curtis M, Dick DJ, Candy JM, Atack JR, Bloxham CA, Blessed G, Fairbairn A, Tomlinson BE, and Perry RH (1985) Cholinergic correlates of cognitive impairment in Parkinson's disease: comparisons with Alzheimer's disease. $J$ Neurol Neurosurg Psychiatry 48:413-421.

Peters JA, Cooper MA, Carland JE, Livesey MR, Hales TG, and Lambert JJ (2010) Novel structural determinants of single channel conductance and ion selectivity in 5-hydroxytryptamine type 3 and nicotinic acetylcholine receptors. J Physiol 588: 587-596.

Peters JA, Malone HM, and Lambert JJ (1993) An electrophysiological investigation of the properties of $5-\mathrm{HT}_{3}$ receptors of rabbit nodose ganglion neurones in culture. Br J Pharmacol 110:665-676.

Petremann M, Tran Van Ba C, Broussy A, Romanet C, and Dyhrfjeld-Johnsen J (2017) Oral administration of clinical stage drug candidate SENS-401 effectively reduces cisplatin-induced hearing loss in rats. Otol Neurotol 38:1355-1361.

Pierce RC and Kumaresan V (2006) The mesolimbic dopamine system: the final common pathway for the reinforcing effect of drugs of abuse? Neurosci Biobehav Rev 30:215-238.

Preskorn SH, Gawryl M, Dgetluck N, Palfreyman M, Bauer LO, and Hilt DC (2014) Normalizing effects of EVP-6124, an $\alpha-7$ nicotinic partial agonist, on event-related potentials and cognition: a proof of concept, randomized trial in patients with schizophrenia. J Psychiatr Pract 20:12-24.

Puig MV, Santana N, Celada P, Mengod G, and Artigas F (2004) In vivo excitation of GABA interneurons in the medial prefrontal cortex through $5-\mathrm{HT}_{3}$ receptors. Cereb Cortex 14:1365-1375

Pytka K, Socała K, Rapacz A, Nieoczym D, Pieróg M, Gryboś A, Siwek A, Waszkielewicz A, and Wlaź P (2017) HBK-14 and HBK-15, triple 5-HT $5-\mathrm{HT}_{7}$ and $5-\mathrm{HT}_{3}$ antagonists with potent antidepressant- and anxiolytic-like properties, increase seizure threshold in various seizure tests in mice. Prog Neuropsychopharmacol Biol Psychiatry 79 (Pt B):378-385.

Rahimian R, Béland LC, and Kriz J (2018) Galectin-3: mediator of microglia responses in injured brain. Drug Discov Today 23:375-381.

Rahimian R, Daneshmand A, Mehr SE, Barzegar-Fallah A, Mohammadi-Rick S, Fakhfouri G, Shabanzadeh AP, and Dehpour AR (2011a) Tropisetron ameliorates ischemic brain injury in an embolic model of stroke. Brain Res 1392:101-109.

Rahimian R, Dehpour AR, Fakhfouri G, Khorramizadeh MR, Ghia J-E, Seyedabadi M, Caldarelli A, Mousavizadeh K, Forouzandeh M, and Mehr SE (2011b) Tropisetron upregulates cannabinoid CB1 receptors in cerebellar granule cells: possible involvement of calcineurin. Brain Res 1417:1-8.

Rahimian R, Ejtemaei Mehr S, Fakhfouri G, and Dehpour AR (2013a) 5-HT receptor $^{2}$ antagonists: new promising therapeutic agents in diabetes and its complications. Acta Med Iran 51:736 
Rahimian R, Fakhfouri G, Ejtemaei Mehr S, Ghia J-E, Genazzani AA, Payandemehr B, Dehpour AR, Mousavizadeh K, and Lim D (2013b) Tropisetron attenuates amyloid-beta-induced inflammatory and apoptotic responses in rats. Eur J Clin Invest 43:1039-1051.

Rahimian R, Lively S, Abdelhamid E, Lalancette-Hebert M, Schlichter L, Sato S, and Kriz J (2019) Delayed galectin-3-mediated reprogramming of microglia after stroke is protective. Mol Neurobiol DOI: 10.1007/s12035-019-1527-0 [published ahead of print].

Rahimian R, Zirak MR, Keshavarz M, Fakhraei N, Mohammadi-Farani A, Hamdi H, and Mousavizadeh K (2016) Involvement of PPAR $\gamma$ in the protective action of tropisetron in an experimental model of ulcerative colitis. Immunopharmacol Immunotoxicol 38:432-440.

Rahimian R, Zirak MR, Seyedabadi M, Keshavarz M, Rashidian A, Kazmi S, Jafarian AH, Karimi G, and Mousavizadeh K (2017) Protective effects of tropisetron on cerulein-induced acute pancreatitis in mice. Biomed Pharmacother 93:589-595.

Raina P, Santaguida P, Ismaila A, Patterson C, Cowan D, Levine M, Booker L, and Oremus M (2008) Effectiveness of cholinesterase inhibitors and memantine for treating dementia: evidence review for a clinical practice guideline. Ann Intern Med 148:379-397.

Rajkumar R and Mahesh R (2010) The auspicious role of the 5-HT3 receptor in depression: a probable neuronal target? J Psychopharmacol 24:455-469.

Rammes G, Eisensamer B, Ferrari U, Shapa M, Gimpl G, Gilling K, Parsons C, Riering K, Hapfelmeier G, Bondy B, et al. (2004) Antipsychotic drugs antagonize human serotonin type 3 receptor currents in a noncompetitive manner. Mol Psychiatry 9:846-858, 818

Rauch SD (2001) Vestibular histopathology of the human temporal bone. What can we learn? Ann N Y Acad Sci 942:25-33.

Ravindran LN and Stein MB (2010) The pharmacologic treatment of anxiety disorders: a review of progress. J Clin Psychiatry 71:839-854.

Redrobe JP and Bourin M (1997) Partial role of 5- $\mathrm{HT}_{2}$ and $5-\mathrm{HT}_{3}$ receptors in the activity of antidepressants in the mouse forced swimming test. Eur $J$ Pharmacol 325:129-135.

Rehani K, Scott DA, Renaud D, Hamza H, Williams LR, Wang H, and Martin M (2008) Cotinine-induced convergence of the cholinergic and PI3 kinase-dependent anti-inflammatory pathways in innate immune cells. Biochim Biophys Acta 1783 375-382.

Reiser G (1990) Mechanism of stimulation of cyclic-GMP level in a neuronal cell line mediated by serotonin $\left(5-\mathrm{HT}_{3}\right)$ receptors. Involvement of nitric oxide, arachidonicacid metabolism and cytosolic $\mathrm{Ca}^{2+}$. Eur J Biochem 189:547-552.

Reznic J and Staubli U (1997) Effects of 5-HT 3 receptor antagonism on hippocampal cellular activity in the freely moving rat. J Neurophysiol 77:517-521.

Rezvani AH, Kholdebarin E, Brucato FH, Callahan PM, Lowe DA, and Levin ED (2009) Effect of R3487/MEM3454, a novel nicotinic $\alpha 7$ receptor partial agonist and $5-\mathrm{HT}_{3}$ antagonist on sustained attention in rats. Prog Neuropsychopharmacol Biol Psychiatry 33:269-275.

Riazi K, Roshanpour M, Rafiei-Tabatabaei N, Homayoun H, Ebrahimi F, and Dehpour AR (2006) The proconvulsant effect of sildenafil in mice: role of nitric oxide-cGMP pathway. Br J Pharmacol 147:935-943.

Richard C and Linthicum FHJ Jr (2012) Vestibular neuritis: the vertigo disappears, the histological traces remain. Otol Neurotol 33:e59-e60.

Ripke S, Neale BM, Corvin A, Walters JTR, Farh K-H, Holmans PA, Lee P, BulikSullivan B, Collier DA, Huang H, et al.; Schizophrenia Working Group of the Psychiatric Genomics Consortium (2014) Biological insights from 108 schizophreniaassociated genetic loci. Nature 511:421-427.

Rodgers RJ (1997) Animal models of 'anxiety': where next? Behav Pharmacol 8: 477-496, discussion 497-504.

Rojas C, Thomas AG, Alt J, Stathis M, Zhang J, Rubenstein EB, Sebastiani S, Cantoreggi S, and Slusher BS (2010) Palonosetron triggers 5- $\mathrm{HT}\left({ }_{3}\right)$ receptor internalization and causes prolonged inhibition of receptor function. Eur J Pharmacol 626:193-199.

Rollema H, Chambers LK, Coe JW, Glowa J, Hurst RS, Lebel LA, Lu Y, Mansbach RS, Mather RJ, Rovetti CC, et al. (2007) Pharmacological profile of the $\alpha 4 \beta 2$ nic otinic acetylcholine receptor partial agonist varenicline, an effective smoking cessation aid. Neuropharmacology 52:985-994.

Romach MK, Kaplan HL, Busto UE, Somer G, and Sellers EM (1998) A controlled trial of ondansetron, a $5-\mathrm{HT}_{3}$ antagonist, in benzodiazepine discontinuation. J Clin Psychopharmacol 18:121-131.

Ropert N and Guy N (1991) Serotonin facilitates GABAergic transmission in the CA1 region of rat hippocampus in vitro. $J$ Physiol 441:121-136.

Rothlin CV, Lioudyno MI, Silbering AF, Plazas PV, Casati ME, Katz E, Guth PS, and Elgoyhen $\mathrm{AB}$ (2003) Direct interaction of serotonin type 3 receptor ligands with recombinant and native $\alpha 9 \alpha 10$-containing nicotinic cholinergic receptors. Mol Pharmacol 63:1067-1074.

Rusnak F and Mertz P (2000) Calcineurin: form and function. Physiol Rev 80: 1483-1521.

Sanchez C, Asin KE, and Artigas F (2015) Vortioxetine, a novel antidepressant with multimodal activity: review of preclinical and clinical data. Pharmacol Ther $\mathbf{1 4 5}$ $43-57$.

Saphier D, Farrar GE, and Welch JE (1995) Differential inhibition of stress-induced adrenocortical responses by $5-\mathrm{HT}_{1 \mathrm{~A}}$ agonists and by $5-\mathrm{HT}_{2}$ and $5-\mathrm{HT}_{3}$ antagonists. Psychoneuroendocrinology 20:239-257.

Sargent AI, Deppe SA, and Chan FA (1993) Seizure associated with ondansetron. Clin Pharm 12:613-615.

Sato N, Sakamori M, Haga K, Takehara S, and Setoguchi M (1992) Antagonistic activity of Y-25130 on 5- $\mathrm{HT}_{3}$ receptors. Jpn J Pharmacol 59:443-448.

Schliebs R and Arendt T (2006) The significance of the cholinergic system in the brain during aging and in Alzheimer's disease. J Neural Transm (Vienna) 113: $1625-1644$

Schneider LS, Dagerman KS, Higgins JP, and McShane R (2011) Lack of evidence for the efficacy of memantine in mild Alzheimer disease. Arch Neurol 68:991-998.
Schreiber BE, Agrup C, Haskard DO, and Luxon LM (2010) Sudden sensorineural hearing loss. Lancet 375:1203-1211.

Schuhmacher A, Mössner R, Quednow BB, Kühn KU, Wagner M, Cvetanovska G, Rujescu D, Zill P, Möller HJ, Rietschel M, et al. (2009) Influence of 5-HT $\mathrm{HT}_{3}$ receptor subunit genes HTR3A, HTR3B, HTR3C, HTR3D and HTR3E on treatment response to antipsychotics in schizophrenia. Pharmacogenet Genomics 19:843-851.

Segal M (1979) Serotonergic innervation of the locus coeruleus from the dorsal raphe and its action on responses to noxious stimuli. $J$ Physiol 286:401-415.

Sell LA, Cowen PJ, and Robson PJ (1995) Ondansetron and opiate craving. A novel pharmacological approach to addiction. Br J Psychiatry 166:511-514.

Semenova TP and Ticku MK (1992) Effects of 5-HT receptor antagonists on seizure susceptibility and locomotor activity in DBA/2 mice. Brain Res 588:229-236.

Sepanjnia K, Modabbernia A, Ashrafi M, Modabbernia MJ, and Akhondzadeh S (2012) Pioglitazone adjunctive therapy for moderate-to-severe major depressive disorder: randomized double-blind placebo-controlled trial. Neuropsychopharmacology 37:2093-2100.

Seyedabadi M, Fakhfouri G, Ramezani V, Mehr SE, and Rahimian R (2014) The role of serotonin in memory: interactions with neurotransmitters and downstream signaling. Exp Brain Res 232:723-738.

Shamash S, Reichert F, and Rotshenker S (2002) The cytokine network of Wallerian degeneration: tumor necrosis factor-alpha, interleukin-1alpha, and interleukin1beta. J Neurosci 22:3052-3060.

Sharma A and Raina V (2001) Generalised seizures following ondansetron. Ann Oncol 12:131-132.

Shen Y, Zhang ZJ, Zhu MD, Jiang BC, Yang T, and Gao YJ (2015) Exogenous induction of HO-1 alleviates vincristine-induced neuropathic pain by reducing spinal glial activation in mice. Neurobiol Dis 79:100-110.

Shimazu T, Inoue I, Araki N, Asano Y, Sawada M, Furuya D, Nagoya H, and Greenberg JH (2005) A peroxisome proliferator-activated receptor-gamma agonist reduces infarct size in transient but not in permanent ischemia. Stroke $\mathbf{3 6}$ 353-359.

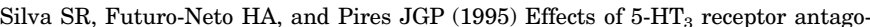
nists on neuroleptic-induced catalepsy in mice. Neuropharmacology 34:97-99.

Simosky JK, Stevens KE, Kem WR, and Freedman R (2001) Intragastric DMXB-A an $\alpha 7$ nicotinic agonist, improves deficient sensory inhibition in DBA/2 mice. Biol Psychiatry 50:493-500.

Singh G, Rees JH, and Sander JW (2007) Seizures and epilepsy in oncological practice: causes, course, mechanisms and treatment. J Neurol Neurosurg Psychiatry 78:342-349.

Singh NN, Rai A, Selhorst JB, and Acharya JN (2009) Ondansetron and seizures. Epilepsia 50:2663-2666.

Soltani F, Sayyah M, Feizy F, Malayeri A, Siahpoosh A, and Motlagh I (2010) A double-blind, placebo-controlled pilot study of ondansetron for patients with obsessive-compulsive disorder. Hum Psychopharmacol 25:509-513.

Spankovich C, Gonzalez VB, Su D, and Bishop CE (2017) Self-reported hearing difficulty, tinnitus, and normal audiometric thresholds, the National Health and Nutrition Examination Survey 1999-2002. Hear Res 358:30-36.

Spilman P, Descamps O, Gorostiza O, Peters-Libeu C, Poksay KS, Matalis A Campagna J, Patent A, Rao R, John V, et al. (2014) The multi-functional drug tropisetron binds APP and normalizes cognition in a murine Alzheimer's model. Brain Res 1551:25-44.

Stachler RJ, Chandrasekhar SS, Archer SM, Rosenfeld RM, Schwartz SR, Barrs DM Brown SR, Fife TD, Ford P, Ganiats TG, et al.; American Academy of Otolaryngology-Head and Neck Surgery (2012) Clinical practice guideline: sudden hearing loss. Otolaryngol Head Neck Surg 146 (Suppl):S1-S35.

Stahl SM (2015) Modes and nodes explain the mechanism of action of vortioxetine, a multimodal agent (MMA): blocking $5 \mathrm{HT}_{3}$ receptors enhances release of serotonin, norepinephrine, and acetylcholine. CNS Spectr 20:455-459.

Stasi C, Bellini M, Bassotti G, Blandizzi C, and Milani S (2014) Serotonin receptors and their role in the pathophysiology and therapy of irritable bowel syndrome. Tech Coloproctol 18:613-621.

Stäubli U and Xu FB (1995) Effects of 5- $\mathrm{HT}_{3}$ receptor antagonism on hippocampal theta rhythm, memory, and LTP induction in the freely moving rat. J Neurosci 15: $2445-2452$

Stegemann A, Sindrilaru A, Eckes B, del Rey A, Heinick A, Schulte JS, Müller FU, Grando SA, Fiebich BL, Scharffetter-Kochanek K, et al. (2013) Tropisetron suppresses collagen synthesis in skin fibroblasts via $\alpha 7$ nicotinic acetylcholine receptor and attenuates fibrosis in a scleroderma mouse model. Arthritis Rheum 65:792-804.

Stępnicki P, Kondej M, and Kaczor AA (2018) Current concepts and treatments of schizophrenia. Molecules 23:E2087.

Steward LJ, Ge J, Bentley KR, Barber PC, Hope AG, Lambert JJ, Peters JA, Blackburn TP, and Barnes NM (1995) Evidence that the atypical 5-HT3 receptor ligand, [3H]-BRL46470, labels additional $5-\mathrm{HT}_{3}$ binding sites compared to [3H]granisetron. $\mathrm{Br} J$ Pharmacol 116:1781-1788.

Stratz C, Bhatia HS, Akundi RS, Nührenberg T, Trenk D, Muñoz E, and Fiebich BL (2012) The anti-inflammatory effects of the $5-\mathrm{HT}_{3}$ receptor antagonist tropisetron are mediated by the inhibition of p38 MAPK activation in primary human monocytes. Int Immunopharmacol 13:398-402.

Stratz Th, Färber L, and Müller W (2002) Local treatment of tendinopathies: comparison between tropisetron and depot corticosteroids combined with local anesthetics. Scand J Rheumatol 31:366-370.

Strupp M and Brandt T (2009) Vestibular neuritis. Semin Neurol 29:509-519.

Sundararajan S, Gamboa JL, Victor NA, Wanderi EW, Lust WD, and Landreth GE (2005) Peroxisome proliferator-activated receptor- $\gamma$ ligands reduce inflammation and infarction size in transient focal ischemia. Neuroscience 130:685-696.

Susswein AJ, Katzoff A, Miller N, and Hurwitz I (2004) Nitric oxide and memory. Neuroscientist 10:153-162.

Swartz MM, Linn DM, and Linn CL (2013) Tropisetron as a neuroprotective agent against glutamate-induced excitotoxicity and mechanisms of action. Neuropharmacology 73:111-121. 
Tanaka K, Yagi T, Shimakoshi R, Azuma K, Nanba T, Ogo H, Tamura A, and Asanuma M (2009) Effects of galantamine on L-NAME-induced behavioral impairment in Y-maze task in mice. Neurosci Lett 462:235-238.

Taniguchi M (2004) Pharmacological characterization of indisetron hydrochloride, as a novel 5- $\mathrm{HT}_{3}$ receptor antagonist. Jpn Pharmacol Ther 32:789-797.

Tatara A, Shimizu S, Shin N, Sato M, Sugiuchi T, Imaki J, and Ohno Y (2012) Modulation of antipsychotic-induced extrapyramidal side effects by medications for mood disorders. Prog Neuropsychopharmacol Biol Psychiatry 38:252-259.

Tecott LH, Maricq AV, and Julius D (1993) Nervous system distribution of the serotonin 5- $\mathrm{HT}_{3}$ receptor mRNA. Proc Natl Acad Sci USA 90:1430-1434.

Thacker MA, Clark AK, Marchand F, and McMahon SB (2007) Pathophysiology of peripheral neuropathic pain: immune cells and molecules. Anesth Analg 105: 838-847.

Thompson AJ (2013) Recent developments in 5- $\mathrm{HT}_{3}$ receptor pharmacology. Trends Pharmacol Sci 34:100-109.

Thompson AJ, Duke RK, and Lummis SCR (2011a) Binding sites for bilobalide, diltiazem, ginkgolide, and picrotoxinin at the $5-\mathrm{HT}_{3}$ receptor. Mol Pharmacol 80 183-190.

Thompson AJ, Jarvis GE, Duke RK, Johnston GAR, and Lummis SCR (2011b) Ginkgolide B and bilobalide block the pore of the 5- $\mathrm{HT}_{3}$ receptor at a location that overlaps the picrotoxin binding site. Neuropharmacology 60:488-495.

Thompson AJ, Lester HA, and Lummis SCR (2010) The structural basis of function in Cys-loop receptors. $Q$ Rev Biophys 43:449-499.

Thompson AJ, Lochner M, and Lummis SCR (2007) The antimalarial drugs quinine, chloroquine and mefloquine are antagonists at $5-\mathrm{HT}_{3}$ receptors. $\mathrm{Br} J$ Pharmacol 151:666-677.

Thompson AJ and Lummis SC (2003) A single ring of charged amino acids at one end of the pore can control ion selectivity in the 5- $\mathrm{HT}_{3}$ receptor. $\mathrm{Br} J$ Pharmacol 140 $359-365$

Thompson AJ and Lummis SCR (2006) $5-\mathrm{HT}_{3}$ receptors. Curr Pharm Des 12 $3615-3630$

Thompson AJ and Lummis SCR (2007) The 5- $\mathrm{HT}_{3}$ receptor as a therapeutic target. Expert Opin Ther Targets 11:527-540.

Thompson AJ and Lummis SCR (2008) Antimalarial drugs inhibit human 5-HT( ${ }_{3}$ ) and $\left.\mathrm{GABA}_{\mathrm{A}}\right)$ but not $\mathrm{GABA}_{\mathrm{C}}$ ) receptors. Br J Pharmacol 153:1686-1696.

Thompson AJ and Lummis SCR (2013) Discriminating between 5- $\mathrm{HT}_{3} \mathrm{~A}$ and 5- $\mathrm{HT}_{3} \mathrm{AB}$ receptors. $\mathrm{Br} \mathrm{J}$ Pharmacol 169:736-747.

Tofaris GK, Patterson PH, Jessen KR, and Mirsky R (2002) Denervated Schwann cells attract macrophages by secretion of leukemia inhibitory factor (LIF) and monocyte chemoattractant protein- 1 in a process regulated by interleukin- 6 and LIF. J Neurosci 22:6696-6703.

Tolk J, Kohnen R, and Müller W (2004) Intravenous treatment of fibromyalgia with the $5-\mathrm{HT}_{3}$ receptor antagonist tropisetron in a rheumatological practice. Scand J Rheumatol Suppl 119:72-75.

Tsang SW, Auyeung KK, Bian ZX, and Ko JK (2016) Pathogenesis, experimental models and contemporary pharmacotherapy of irritable bowel syndrome: story about the brain-gut axis. Curr Neuropharmacol 14:842-856.

Tuerke KJ, Limebeer CL, Fletcher PJ, and Parker LA (2012) Double dissociation between regulation of conditioned disgust and taste avoidance by serotonin availability at the $5-\mathrm{HT}_{3}$ ) receptor in the posterior and anterior insular cortex J Neurosci 32:13709-13717.

Turner TJ, Mokler DJ, and Luebke JI (2004) Calcium influx through presynaptic $5-\mathrm{HT}_{3}$ receptors facilitates GABA release in the hippocampus: in vitro slice and synaptosome studies. Neuroscience 129:703-718.

Tyler K, Moriceau S, Sullivan RM, and Greenwood-van Meerveld B (2007) Long-term colonic hypersensitivity in adult rats induced by neonatal unpredictable vs predictable shock. Neurogastroenterol Motil 19:761-768.

Utsumi D, Matsumoto K, Amagase K, Horie S, and Kato S (2016) 5- $\mathrm{HT}_{3}$ receptors promote colonic inflammation via activation of substance $\mathrm{P} /$ neurokinin-1 receptor in dextran sulphate sodium-induced murine colitis. $\mathrm{Br} J$ Pharmacol $\mathbf{1 7 3}$ $1835-1849$.

Valenti O, Cifelli P, Gill KM, and Grace AA (2011) Antipsychotic drugs rapidly induce dopamine neuron depolarization block in a developmental rat model of schizophrenia. J Neurosci 31:12330-12338.

Van Ameringen M, Patterson B, and Simpson W (2014) DSM-5 obsessive-compulsive and related disorders: clinical implications of new criteria. Depress Anxiety 31 487-493.

Venail F, Biboulet R, Mondain M, and Uziel A (2012) A protective effect of 5- $\mathrm{HT}_{3}$ antagonist against vestibular deficit? Metoclopramide versus ondansetron the early stage of vestibular neuritis: a pilot study. Eur Ann Otorhinolaryngol Head Neck Dis 129:65-68.

Volkow ND and Morales M (2015) The brain on drugs: from reward to addiction. Cell 162:712-725.

Wada Y, Shiraishi J, Nakamura M, and Koshino Y (1997) Effects of the 5-HT ceptor agonist 1-(m-chlorophenyl)-biguanide in the rat kindling model of epilepsy. Brain Res 759:313-316.

Walker MF (2009) Treatment of vestibular neuritis. Curr Treat Options Neurol 11: $41-45$

Walstab J, Hammer C, Bönisch H, Rappold G, and Niesler B (2008) Naturally occurring variants in the $H T R 3 B$ gene significantly alter properties of human heteromeric 5-hydroxytryptamine-3A/B receptors. Pharmacogenet Genomics 18 $793-802$
Walstab J, Kruger D, Stark T, Hofmann T, Demir IE, Ceyhan GO, Feistel B, Schemann M, and Niesler B (2013) Ginger and its pungent constituents noncompetitively inhibit activation of human recombinant and native 5-HT3 receptors of enteric neurons. Neurogastroenterol Motil 25:439-447, e302.

Walstab J, Rappold G, and Niesler B (2010) 5-HT( $\left.{ }_{3}\right)$ receptors: role in disease and target of drugs. Pharmacol Ther 128:146-169.

Walstab J, Wohlfarth C, Hovius R, Schmitteckert S, Röth R, Lasitschka F, Wink M, Bönisch H, and Niesler B (2014) Natural compounds boldine and menthol are antagonists of human $5-\mathrm{HT}_{3}$ receptors: implications for treating gastrointestinal disorders. Neurogastroenterol Motil 26:810-820.

Wang RY, Ashby CR Jr, Edwards E, and Zhang JY (1994) The role of 5-HT3-like receptors in the action of clozapine. J Clin Psychiatry 55 (Suppl B):23-26.

Watanabe K, Ashby CR Jr, Katsumori H, and Minabe Y (2000) The effect of the acute administration of various selective 5 -HT receptor antagonists on focal hippocampal seizures in freely-moving rats. Eur $J$ Pharmacol 398:239-246.

Watling KJ, Beer MS, Stanton JA, and Newberry NR (1990) Interaction of the atypical neuroleptic clozapine with $5-\mathrm{HT}_{3}$ receptors in the cerebral cortex and superior cervical ganglion of the rat. Eur J Pharmacol 182:465-472.

Weber S, Volynets V, Kanuri G, Bergheim I, and Bischoff SC (2009) Treatment with the $5-\mathrm{HT}_{3}$ antagonist tropisetron modulates glucose-induced obesity in mice. Int $J$ Obes 33:1339-1347.

White FA, Sun J, Waters SM, Ma C, Ren D, Ripsch M, Steflik J, Cortright DN, Lamotte RH, and Miller RJ (2005) Excitatory monocyte chemoattractant protein-1 signaling is up-regulated in sensory neurons after chronic compression of the dorsal root ganglion. Proc Natl Acad Sci USA 102:14092-14097.

Wildeboer KM, Zheng L, Choo KS, and Stevens KE (2009) Ondansetron results in improved auditory gating in $\mathrm{DBA} / 2$ mice through a cholinergic mechanism. Brain Res 1300:41-50.

Wozniak KM, Pert A, and Linnoila M (1990) Antagonism of 5-HT $\mathrm{H}_{3}$ receptors attenuates the effects of ethanol on extracellular dopamine. Eur J Pharmacol 187: 287-289.

Yakel JL and Jackson MB (1988) 5 - $\mathrm{HT}_{3}$ receptors mediate rapid responses in cultured hippocampus and a clonal cell line. Neuron 1:615-621.

Yamada K, Hattori E, Iwayama Y, Ohnishi T, Ohba $\mathrm{H}$, Toyota T, Takao $\mathrm{H}$, Minabe $\mathrm{Y}$, Nakatani N, Higuchi T, et al. (2006) Distinguishable haplotype blocks in the $H T R 3 A$ and $H T R 3 B$ region in the Japanese reveal evidence of association of HTR3B with female major depression. Biol Psychiatry 60:192-201.

Yamashita D, Jiang HY, Schacht J, and Miller JM (2004) Delayed production of free radicals following noise exposure. Brain Res 1019:201-209.

Yang AC and Tsai SJ (2017) New targets for schizophrenia treatment beyond the dopamine hypothesis. Int $J \mathrm{Mol}$ Sci 18:1-14.

Yang KH, Galadari S, Isaev D, Petroianu G, Shippenberg TS, and Oz M (2010) The nonpsychoactive cannabinoid cannabidiol inhibits 5-hydroxytryptamine3A receptor-mediated currents in Xenopus laevis oocytes. J Pharmacol Exp Ther 333: 547-554.

Yang WP, Henderson D, Hu BH, and Nicotera TM (2004) Quantitative analysis of apoptotic and necrotic outer hair cells after exposure to different levels of continuous noise. Hear Res 196:69-76.

Yu H, Pardoll D, and Jove R (2009) STATs in cancer inflammation and immunity: a leading role for STAT3. Nat Rev Cancer 9:798-809.

Yu Y, Zhu W, Liang Q, Liu J, Yang X, and Sun G (2018) Tropisetron attenuates lipopolysaccharide induced neuroinflammation by inhibiting NF- $\mathrm{B}$ and SP/NK1R signaling pathway. J Neuroimmunol 320:80-86.

Zakrzewski JL (2003) Cyclosporin A-associated status epilepticus related to hematopoietic stem cell transplantation for thalassemia. Pediatr Hematol Oncol 20 $481-486$

Zhai J, Gershon MD, Walsh JH, Wong HC, and Kirchgessner AL (1999) Inward currents in neurons from newborn Guinea pig intestine: mediation by 5-hydroxytryptamine type 3 receptors. J Pharmacol Exp Ther 291:374-382.

Zhang XY, Liu L, Liu S, Hong X, Chen DC, Xiu MH, Yang FD, Zhang Z, Zhang X, Kosten TA, et al. (2012) Short-term tropisetron treatment and cognitive and P50 auditory gating deficits in schizophrenia. Am J Psychiatry 169:974-981.

Zhang Z-J, Kang W-H, Li Q, Wang X-Y, Yao S-M, and Ma A-Q (2006) Beneficial effects of ondansetron as an adjunct to haloperidol for chronic, treatment-resistant schizophrenia: a double-blind, randomized, placebo-controlled study. Schizophr Res 88:102-110.

Zhao H, Lin Y, Chen S, Li X, and Huo $\mathrm{H}$ (2018) $5-\mathrm{HT}_{3}$ receptors: a potential therapeutic target for epilepsy. Curr Neuropharmacol 16:29-36.

Zohar J and Insel TR (1987) Obsessive-compulsive disorder: psychobiological approaches to diagnosis, treatment, and pathophysiology. Biol Psychiatry 22: 667-687.

Zohar J, Zohar-Kadouch RC, and Kindler S (1992) Current concepts in the pharmacological treatment of obsessive-compulsive disorder. Drugs 43:210-218.

Zoldan J, Friedberg G, Livneh M, and Melamed E (1995) Psychosis in advanced Parkinson's disease: treatment with ondansetron, a 5- $\mathrm{HT}_{3}$ receptor antagonist. Neurology 45:1305-1308.

Zoldan J, Friedberg G, Weizman A, and Melamed E (1996) Ondansetron, a 5-HT antagonist for visual hallucinations and paranoid delusional disorder associated with chronic L-DOPA therapy in advanced Parkinson's disease. Adv Neurol 69: 541-544.

Zovkic IB and Sweatt JD (2013) Epigenetic mechanisms in learned fear: implications for PTSD. Neuropsychopharmacology 38:77-93. 